NBER WORKING PAPER SERIES

\title{
WOMEN'S SUFFRAGE AND CHILDREN'S EDUCATION
}

\author{
Esra Kose \\ Elira Kuka \\ Na'ama Shenhav \\ Working Paper 24933 \\ http://www.nber.org/papers/w24933
NATIONAL BUREAU OF ECONOMIC RESEARCH
1050 Massachusetts Avenue
Cambridge, MA 02138 \\ August 2018
}

We thank Doug Miller, Marianne Page, Hilary Hoynes, Scott Carrell, and Peter Lindert for many helpful conversations and support. We are also grateful for the input that we received from Marcella Alsan, Celeste Carruthers, Bill Collins, Andrew Goodman-Bacon, Elizabeth Cascio, Claudia Goldin, Jonathan Homola, JaeWook Jung, Erzo Luttmer, Paco Martorell, Bhash Mazumder, Chris Meissner, Claudia Olivetti, Giovanni Peri, Sarah Reber, Shu Shen, Dawn Teele, Marianne Wanamaker, and seminar participants at the APSA Annual Meeting, the Chicago Fed, the Economic Demography Workshop, the Historical Women's Movement Workshop at UPenn, NBER DAE Summer Institute, SoCCAM, the Stata Texas Empirical Microeconomics Conference, UC Davis, UC Berkeley Political Economy Seminar, the University of Oklahoma, and Wellesley College. We benefited from data made publicly available by Daniel Aaronson and Bhash Mazumder; Daron Acemoglu, David Autor, and David Lyle; Claudia Goldin; Lawrence Kenny; and Adriana Lleras-Muney. Our work was supported by a generous grant from the AllUC History Group, a Sam Taylor Fellowship, and a National Academy of Education/Spencer Dissertation Fellowship. An earlier version of this paper circulated under the titles "Who Benefited from Women's Suffrage?" and "Women's Enfranchisement and Children's Education: The Long-Run Impact of the U.S. Suffrage Movement." All errors are our own. The views expressed herein are those of the authors and do not necessarily reflect the views of the National Bureau of Economic Research.

NBER working papers are circulated for discussion and comment purposes. They have not been peer-reviewed or been subject to the review by the NBER Board of Directors that accompanies official NBER publications.

(C) 2018 by Esra Kose, Elira Kuka, and Na'ama Shenhav. All rights reserved. Short sections of text, not to exceed two paragraphs, may be quoted without explicit permission provided that full credit, including $(\subset$ notice, is given to the source. 
Women's Suffrage and Children's Education

Esra Kose, Elira Kuka, and Na'ama Shenhav

NBER Working Paper No. 24933

August 2018, Revised June 2020

JEL No. I0,N30

\begin{abstract}
While a growing literature shows that women, relative to men, prefer greater investment in children, it is unclear whether empowering women produces better economic outcomes. Exploiting plausibly exogenous variation in U.S. suffrage laws, we show that exposure to suffrage during childhood led to large increases in educational attainment for children from disadvantaged backgrounds, especially blacks and Southern whites. We also find that suffrage led to higher earnings alongside education gains, although not for Southern blacks. Using newlydigitized data, we show that education increases are primarily explained by suffrage-induced growth in education spending, although early-life health improvements may have also contributed.

Esra Kose

Bucknell University

Department of Economics

One Dent Drive

Lewisburg, PA 17837

esra.kose@bucknell.edu

Elira Kuka

Economics Department

The George Washington University

2115 G Street NW

Monroe Hall 340

Washington, DC 20052

and NBER

ekuka@gwu.edu

\author{
Na'ama Shenhav \\ Department of Economics \\ Dartmouth College \\ 6106 Rockefeller Hall \\ Hanover, NH 03755 \\ and NBER
}

naama.shenhav@dartmouth.edu
\end{abstract}


Gender differences in social preferences have been documented across many settings. For instance, there is evidence that women favor higher levels of investment in children, are more pro-social, and are more egalitarian. ${ }^{1}$ Thus, it has been argued that female empowerment could lead to greater investment in human capital and increase economic development (Duflo, 2012). However, there is little empirical evidence that increase in women's influence leads to different policies or better economic outcomes. In this paper, we provide new evidence of the impact of enfranchising women in the U.S. on the human capital of the next generation.

The passage of women's suffrage laws in the U.S. has been hailed as a "turning point in our Nation's history" (Obama, 2010): newly-empowered women exercised their vote in large numbers (Lott and Kenny, 1999) and post-suffrage legislators voted for more progressive policies and more funds for public health, social services, and (at least in the South) education (Lott and Kenny, 1999; Miller, 2008; Carruthers and Wanamaker, 2014). There is also some evidence that changes in health spending led to a decline in child mortality (Miller, 2008).

Building on these earlier findings, we estimate the long-run impact of exposure to suffrage during childhood on education and labor market outcomes. To examine mechanisms, we use newly-digitized historical records to estimate the short-run impact of suffrage on local education expenditures, school enrollment, and infant mortality.

Theoretically, it is ambiguous whether women's suffrage would lead to long term gains in education, and for whom. While studies show that public spending on health, social services, and, to some extent, education increased on average, these effects may not lead to education gains if spending was increased for populations with few gains from spending. For instance, some evidence suggests that the returns to education spending are largest for those with few resources (Jackson, Johnson and Persico, 2016; Lafortune, Rothstein and Schanzenbach, 2018; Carruthers and Wanamaker, 2013). Thus, suffrage may have had little impact on education if newly-empowered women advocated that funding only go to populations with greater political or economic influence (e.g., more-educated whites).

Our analysis exploits variation in the timing of suffrage laws, as in John R. Lott and Lawrence W. Kenny (1999) and Miller (2008), and differential exposure to the laws across cohorts, in a difference-in-difference design. Thus, for each state, we compare the outcomes of individuals who were older than fifteen when suffrage was passed (comparison) to individuals who were at most age fifteen when suffrage was passed (treated). The staggered adoption of suffrage laws allows us to include detailed birth-cohort-by-region fixed effects to control for other potential changes across cohorts. This design thus relies on the assumption that differential exposure to suffrage - among individuals in the same region and birth cohort -

\footnotetext{
${ }^{1}$ See, e.g., Duflo (2003); Lundberg, Pollak and Wales (1997); Andreoni and Vesterlund (2001); Croson and Gneezy (2009); Alesina and Giuliano (2011); Ashok, Kuziemko and Washington (2015).
} 
only affects outcomes through suffrage-induced changes in human capital inputs.

We provide several pieces of evidence in favor of the identifying assumption. First, we use event studies to show that suffrage is not correlated with trends in our outcomes of interest. Second, we show that the timing of suffrage is not correlated with pre-suffrage state demographics (trends or levels), education policies, or the passage of other progressive laws. Thus, any remaining confounders would need to be correlated with the timing of suffrage and outside the extensive set of state covariates and progressive laws in our controls.

We bring together multiple historical data sources to examine the impacts of suffrage. We use the 1940, 1950 and 1960 decennial censuses to estimate the effects of suffrage on individuals' education and labor market outcomes. Additionally, we digitized city-level records from 1909 to 1927 to examine countrywide impacts on school enrollment, school expenditures, and state and local revenue for schooling. Finally, we digitized counts of deaths for each state, age, race, and gender from 1900 to 1932 to estimate impacts on mortality.

Our primary finding is that exposure to women's suffrage during childhood led to meaningful gains in educational attainment, particularly for children from economically disadvantaged backgrounds. Full exposure to suffrage between the ages of 0 and 15 increased educational attainment by 0.9 years for black children (who averaged 5.2 years of education pre-suffrage) and by one year for white children from the South (who averaged 8.0 years of education pre-suffrage.) In contrast, full exposure to suffrage led to between 0.3 and 0.5 years of additional education for whites in the Northeast and in the West (who averaged 9.0 years of education pre-suffrage.) Consistent with this, we show that suffrage had significantly larger effects on the education of youth from states that had low average levels of education pre-suffrage.

We also find that suffrage increased earnings along with education, although not for Southern blacks. This is consistent with prior evidence that low school quality together with labor market discrimination reduced the returns to schooling for this group (see, e.g., Card and Krueger, 1992).

To explain the large and heterogeneous effects on education, we show that suffrage had disparate impacts on school spending across the country. On average, suffrage led to a 13.9\% increase in schooling expenditures within five years. However, expenditures post-suffrage increased more in percent terms in cities in the South and in states with lower average presuffrage education. For example, spending on education increased by nearly twice as much in the South (23 percent) as in the non-South (13 percent.) Drawing on previous estimates of the impact of education spending (Jackson, Johnson and Persico, 2016), we calculate that growth in education spending could explain $110 \%, 95 \%$, and $73 \%$ of the education impacts for Southern whites, Southern blacks, and blacks nationwide. Altogether, this suggests that 
education spending is very likely to be the primary mechanism for our education effects.

We find less evidence that improvements in early-life health - proxied by reductions in infant mortality - can explain post-suffrage gains in education. In particular, contrary to our impacts on education, mortality improvements post-suffrage are small for blacks outside the South and are significant for whites in the non-South. Thus, while improvements in health may have contributed to increases in schooling, this does not appear to be a main channel for education gains.

We bolster the plausibility of these results by providing additional evidence on political mechanisms and on the mechanics of spending in the South. First, we show that suffrage increased voting for progressive bills in the Senate both by increasing "yay" votes by legislators elected post-suffrage and by reducing "nay" votes by incumbent legislators. Thus, suffrage appears to have swayed the votes of existing legislators in addition to changing the composition of legislators (Morgan-Collins, 2019). Second, we show that in the South, 10 percent growth in local education spending translated to 10 percent growth in spending in white schools and 5.2 to 6.3 percent growth in spending black schools. This indicates that even in the presence of racism in the South, the growth in education spending post-suffrage is likely to have been at least modestly passed on to black schools.

This paper touches on several literatures. First, we add to the work on the broad effects of women's political representation on public spending and children's outcomes. The closest studies in this area show that electing women to public office in India leads to greater investment in female-preferred public goods and increases primary educational attainment (Chattopadhyay and Duflo, 2004; Clots-Figueras, 2012), but that electing women to local office in the U.S. has little impact on spending (Ferreira and Gyourko, 2014). Our findings suggest that women's voting en masse can have wide-reaching effects on children's outcomes akin to the best-case effects of increasing women's representation.

Second, we add to the set of studies on the impact of suffrage on policy outcomes and children's well-being (see Lott and Kenny, 1999; Miller, 2008; Carruthers and Wanamaker, 2014, summarized above, and Aidt and Dallal, 2008). We make three additions to this literature. Our first addition is that we show that childhood exposure to suffrage led to large and lasting improvements in human capital. We document that impacts on education were widespread, geographically and racially, larger in less advantaged areas, and extended beyond the children of those with the greatest gains in political power post-suffrage.

Our second addition is that we provide the first national accounting of the impacts of suffrage on local education spending. This builds on Carruthers and Wanamaker (2014), who broke ground by showing that suffrage increased local schooling expenditures in 3 Southern states. We show that geographic variation in the impact of suffrage on spending is important 
for explaining heterogeneous effects on education.

As a third, more minor addition, we also provide evidence that suffrage changed the voting behavior of incumbent politicians towards abstention. This is a likely mechanism for the rise in the passage of progressive bills post-suffrage shown in earlier work (Miller, 2008), together with the election of new, less-conservative legislators (Morgan-Collins, 2019). It also provides empirical evidence that women's lobbying changed legislators' voting behavior, which is frequently mentioned in historical accounts.

Finally, we contribute to the literature on the impact of public spending on educational attainment (e.g., Jackson, Johnson and Persico, 2016; Hyman, 2017). The fact that we find similar gains in education for blacks and whites in the South, despite the fact that whites likely experienced almost twice the increase in education expenditures, provides additional evidence of potential diminishing returns to education spending (Carruthers and Wanamaker, 2013).

The remainder of the paper continues as follows. In Section 1 we provide institutional background on the passage of suffrage laws and present evidence of the short-run impacts of suffrage on voting and the passage of progressive bills. We discuss the expected effects of suffrage on education in Section 2. Section 3 describes our data sources, followed by an overview of our empirical strategy in Section 4. We present our main results on the longrun effects of suffrage in Section 5, followed by evidence on mechanisms in Section 6, and robustness checks in Section 7. We conclude in Section 8.

\section{Background on Women's Suffrage}

At the turn of the $20^{\text {th }}$ century, women had few, if any, political rights (Baker, 1984; Keyssar, 2000). ${ }^{2}$ Thus, the passage of suffrage laws in the early part of the century provided the first opportunity for many women to enter into the political sphere, and influence political outcomes and local policy.

De jure, suffrage laws applied to all women. But de facto, black women's participation was severely limited by the presence of literacy tests, poll taxes, and fear of retribution in the South (Cascio and Washington, 2013; Naidu, 2012). Hence, access to voting following suffrage was largely limited to white women. In spite of this, suffrage led to a significant shift in the electorate and in policymakers' priorities, as we discuss below.

\footnotetext{
${ }^{2}$ The most common form of political voice for women was the right to vote for school boards, although anecdotally school elections had low female participation (Youmans, 1921). School board voting rights were extended during the mid- to late- $19^{\text {th }}$ century in 21 states (Keyssar, 2000). Since these laws preceded the passage of state and presidential suffrage by over 30 years, our results should be interpreted as the effect of full voting rights above any existing school voting rights.
} 
Figure 1 illustrates the timing of the passage of the first suffrage law in each state using data from Lott and Kenny (1999) and Miller (2008). ${ }^{3}$ In our analysis, we exploit the variation in suffrage laws passed after 1900, beginning with Washington in 1910. ${ }^{4}$ Between 1910 and 1919, an additional 24 states passed suffrage laws. In 1920, the US ratified the Nineteenth Amendment, which guaranteed that sex could not be used as a basis of exclusion from voting. Three-fourths of the 48 states voted in support of ratification, and the remaining 12 states, labeled as "Mandated" in Figure 1, adopted it by mandate in 1920.

Historical accounts suggest that suffrage led to increased attention and support for policies targeting children's welfare. For example, one year after the passage of suffrage in North Carolina, "politicians passed unusually liberal appropriations' for the states educational and child-caring institutions (Schuyler (2006), p.171)." This appears to have been due to the election of new, progressive legislators (Morgan-Collins, 2019) and to women's lobbying of existing legislators. In particular, women's lobbies created the perception of a close political alignment among its members, which appears to have made politicians more willing to support progressive legislation (Lemons, 1973; Moehling and Thomasson, 2012). ${ }^{5}$ We provide empirical evidence supporting this narrative - that suffrage had an impact of suffrage on legislators' voting patterns - below, in Section 1.1.

Because suffrage increased voting primarily for white women, one might expect gains primarily for white children. However, there are reasons to suspect that there could be some gains for black children as well. While black women in the South could not directly lobby legislators, there is qualitative evidence that black women's organizations had some (infrequent) success in convincing white women's organizations to request funds for black youth. For instance, this form of cooperation led to the founding of the Fairworld School for Negro girls in South Carolina, and of a training school for "delinquent African American boys" in North Carolina (Schuyler, 2006, p.156-158). Similar examples also led to funding for homes for delinquent black children (Schuyler, 2006, p. 171). In that sense, suffrage may have reduced the costs of gaining access to policymakers not only for white women, but also

\footnotetext{
${ }^{3}$ Following the prior literature, our focus is the timing of the earliest state or presidential suffrage law passed in the state, since subsequent laws may have been passed strategically in anticipation of the Nineteenth Amendment. Presidential-only suffrage laws were passed in Illinois, Indiana, Iowa, Maine, Minnesota, Missouri, North Dakota, Ohio, Rhode Island, Tennessee, Vermont and Wisconsin. Arkansas and Texas, instead, passed primary-only laws (Miller, 2008). See Teele (2018) and Keyssar (2000) for greater detail on the passage of suffrage laws.

${ }^{4}$ This helps balance exposure to suffrage across states in our sample, as we discuss in Section 3.

${ }^{5}$ As an example of the successful organization of women, in the Virginia gubernatorial election in 1921, former anti-suffragist George Tucker was handily defeated due to opposition from the League of Women Voters. The League instead endorsed the opposing candidate, Elbert Trinkle, for his support of progressive legislation, including improved roads to allow rural children to attend school. Further, Westmoreland Davis, the previous Virginia governor who had endorsed Tucker, lost his bid for the Senate (Walker, Dunn and Dunn, 2003).
} 
for black women (at least for issues related to child welfare.)

A second channel for gains for black children is that a portion of suffrage-induced education spending may have simply been "passed-through" to black schools through fixed allocation mechanisms (or norms.) We quantify the likely magnitude of such pass-through in Section 6.

\subsection{Voting, Progressive Legislation, and Public Spending Post- Suffrage}

The passage of suffrage laws has been linked to an immediate and significant change in voter participation in gubernatorial elections nationwide, and other elections in specific states (Lott and Kenny, 1999; Corder and Wolbrecht, 2016); and in the passage of progressive legislation in Congress, particularly in the Senate (Lott and Kenny, 1999; Miller, 2008). Because these mechanisms are relevant for impacts on public spending and education, we briefly re-examine these outcomes to verify the immediacy of the effects on voter turnout and the plausibility of rapid effects in the Senate.

First, we examine the relationship between the passage of suffrage laws and voting in presidential elections, which typically have higher turnout than other races (Cascio and Washington, 2013). We illustrate changes in voting around suffrage by regressing the log of the number of votes relative to the population over 21 on event-time indicators for the years around the passage of suffrage (using the timing of suffrage laws in Figure 1), together with state and election-year fixed effects. Appendix Figure A.1 shows that voter participation increased by 45 log points, or 56 percent, in the year after suffrage. Consistent with prior work, this suggests that suffrage significantly expanded the voting population, although women voted at roughly half the rate of men.

Second, we consider whether suffrage had impacts on the progressive voting of existing legislators, which could have hastened the post-suffrage change in policies. In particular, we measure the impact of suffrage on progressive voting by all Senators (as in Miller, 2008), which includes changes in the composition of elected Senators, and as well as by Senators present before and after suffrage ("incumbents.") ${ }^{6}$

Panel A of Appendix Table A.1 shows that, conditional on state and year fixed effects, suffrage leads to a significant rise in the propensity to vote in favor of a progressive bill, consistent with Miller (2008). Panel B shows that, conditional on individual and year fixed

\footnotetext{
${ }^{6}$ In particular, we first regress the share of progressive bills for which a Senator votes in a particular way (yay, nay, or abstains) on an indicator for the years after suffrage along with year and state fixed effects. We include individual fixed effects when we examine incumbents. For details on the coding of progressive bills and voting data, see Appendix B.
} 
effects, incumbents are more likely to abstain from votes on progressive bills post-suffrage. This comes from a decline in voting against progressive bills. ${ }^{7}$ Thus, suffrage appears to have both increased voting for progressive bills by newly-elected senators, which drives the overall effect, and reduced voting against progressive bills by incumbents. The presence of both of these channels helps to explain the rapid change in legislation following suffrage.

Multiple studies show that suffrage led to an increase in public spending, particularly on health (by up to 36\%) and social programs (by up to 24\%) (Lott and Kenny, 1999; Miller, 2008). However, there is inconsistent evidence of impacts on education spending. While Lott and Kenny (1999) and Miller (2008) find no effect of suffrage on state-level education spending across the country, Carruthers and Wanamaker (2014) find positive effects of suffrage on county-level education spending for three Southern states, with larger impacts for white schools relative to black schools.

While these earlier studies of education spending provide important insights into the impacts of suffrage, each of them has critical limitations. First, Lott and Kenny (1999) and Miller (2008) focus on state spending, which accounted for less than $20 \%$ of local education expenditures during this period (Benson and O'Halloran, 1987). Thus, their null estimates may not capture the full effects of suffrage. Second, the estimates in Carruthers and Wanamaker (2014) may be specific to the South (or a subset of the South.) Third, the estimates in Carruthers and Wanamaker (2014) rely on variation in the white female share across counties, which could be measured with error and may not necessarily correspond to a larger "dose" of suffrage. ${ }^{8}$ This could lead to attenuation or reduced precision in the estimates. To fill these gaps, in Section 6, we revisit the effects of suffrage on education expenditures using new historical data on city-level spending that has national coverage.

\section{Expected Effects of Suffrage}

We hypothesize that increases in public spending on health and education are two main channels by which suffrage would have impacted education. In this section, we briefly discuss the predicted education effects of these channels, other potential mechanisms, and testable hypotheses.

The predicted effect of greater health spending on education is ambiguous. On the one hand, reductions in the prevalence of disease are likely to reduce the duration or severity of

\footnotetext{
${ }^{7}$ Event studies in Appendix Figure A.2 illustrate that these changes incumbent voting took place immediately after suffrage. They also show that the results are robust to including region-by-year and state trends, although the inclusion of trends sometimes introduces pre-trends where there are none.

${ }^{8}$ For instance, counties with a smaller share of white women may experience a bigger impact of suffrage if the discrepancy between men and women's preferences for spending is larger in those counties.
} 
sickness spells. This would lead to increases in school attendance post-suffrage. On the other hand, reductions in mortality (as shown in Miller, 2008) would lead to a greater presence of weak survivors. This would tend to reduce estimated impacts on completed education. We can not observe reductions in sickness to examine the first channel; however, in Section 6 we use bounding methods to estimate the role of survivors in our education effects.

The predicted effect of education spending on education is generally positive. However, there is evidence that education gains may be larger for groups with lower pre-suffrage spending. As one example, studies of the philanthropic "Rosenwald Initiative" - which was closely timed with suffrage - show that black children benefited more from increases in school spending than white children (Aaronson and Mazumder, 2011; Carruthers and Wanamaker, 2013). Similarly, school spending increases have been shown to have strong impacts on education outcomes in districts with low levels of spending (Jackson, Johnson and Persico, 2016; Hyman, 2017; Lafortune, Rothstein and Schanzenbach, 2018). To test for this form of heterogeneity in our setting, we estimate differential impacts of suffrage by race as well as by pre-suffrage average education in the state. ${ }^{9}$

Finally, changes in women's bargaining power in households or in girls' aspirations could also lead to improvements in education. We expect changes in bargaining power to primarily benefit white children, since black women were largely disenfranchised. Suffrage could also make girls more motivated to remain in school (e.g., from a desire to become an educated voter, changes in gender norms, or greater investment from parents.) Thus, we test for larger education gains for women post-suffrage.

\section{Data}

One of the strengths of our analysis is the large number of data sources we access to provide the most comprehensive description of the effects of suffrage on human capital. For brevity, we provide an overview of the data sources here and include detailed descriptions in Appendix B.

Long-Run Outcomes We analyze the effect of women's suffrage laws on children's educational and labor market outcomes using two samples constructed from the 1920-1930 and 1940-1960 U.S. decennial censuses, respectively. The data for each census year are a $1 \%$ representative sample of the U.S. population and are publicly available through the

\footnotetext{
${ }^{9}$ Although we discuss the impacts of health and education spending separately, there could be interactions between these effect; positive, if healthy students are more attentive, or negative if health improvements lead to classroom overcrowding.
} 
Integrated Public Use Microdata Series (IPUMS) (Ruggles et al., 2020). Relevant for our research design, the samples contain information on individuals' year and state of birth, as well as years of completed education and earnings for each individual (for the 1940-1960 censuses) and literacy (for the 1920-1930 censuses). ${ }^{10}$

Our main analysis sample for educational attainment and labor market outcomes includes individuals who are (i) at least 20 years old at the time of the census and (ii) were born between 1880 and 1930 in states that adopted suffrage between 1910 and $1920 .{ }^{11}$ This ensures that for each state that passed suffrage between 1910 and 1920, we observe individuals born between 30 years before suffrage and up to 10 years after suffrage. ${ }^{12}$ For our analysis of impacts on literacy, we expand the sample to include individuals ages 15 and above (Aaronson and Mazumder, 2011).

State-Level Controls For controls, we merge on state-by-cohort measures of the demographic and economic composition of the state and measures of exposure to other education policies. These include the percentage female; population; percentage white; percentage black; percentage illiterate; employment in manufacturing; total wages paid in manufacturing; total value of farm property; percentage urban population; and percentage foreign born. We also control for the state-by-cohort compulsory attendance requirement, the child labor educational requirement (following Stephens and Yang, 2014), and exposure to the Rosenwald Initiative during childhood (following Aaronson and Mazumder, 2011).

Mortality Counts To perform detailed analyses of the impact of suffrage on mortality, we digitized annual counts of deaths by state, age, race, and gender from 1900 to 1932 from the Mortality Statistics. The data include all deaths from participating states, which grew from 10 states in 1900 to 48 states by 1932 .

Education Spending and School Enrollment To examine education spending and enrollment patterns, we digitized city-level enrollment, education expenditures, and revenue sources from the Report of the Commissioner of Education and Biennial Survey of Education for cities with populations of 10,000 and over. Each report contains data for a single academic

\footnotetext{
${ }^{10}$ We drop observations where years of education or income were imputed by the census. The 1950 Census only collected years of education for one individual per household, so we have fewer observations for that year.

${ }^{11}$ Hence, we exclude individuals born in the early-adopter states Colorado, Idaho, Utah and Wyoming. We also exclude those born in Alaska, the District of Columbia and Hawaii, which were not U.S. states by 1920 , and for which we do not have either a date of suffrage or state-level controls.

${ }^{12}$ Our results remain the same if we keep states that passed suffrage prior to 1910 or keep individuals over age 25 - see Section 7.
} 
year (e.g., 1909 to 1910), which we will hereafter refer to by the calendar year of the start of the term (e.g., 1909). We digitized the annual reports from 1909 to 1911 and 1913 to 1915 and the biennial reports from 1917 and 1927 (12 academic years in total).

For our main analyses, we keep cities for which we have information on enrollment, spending, and revenues, and which have available information for at least 7 of the 12 years. This helps achieve balance across years and across outcomes. ${ }^{13}$ We drop cities that we identify as outliers, defined as having enrollment and spending above the 99th percentile. Our final dataset contains city-year observations with enrollment, spending, and revenue from 1909 through 1927 for 42 states and 523 cities. This is the most comprehensive data on education spending used to analyze the impacts of suffrage to date. ${ }^{14}$

\section{Empirical Strategy}

We estimate the effect of suffrage using a difference-in-differences framework that compares the outcomes of cohorts who in the year that suffrage was passed in their state of birth were beyond schooling-age ("comparison"), at schooling age or not yet in school ("partially exposed"), and not yet born ("fully exposed"). We define exposure using state of birth because it is less likely to be an outcome of suffrage than state of residence and provides a reasonable proxy for childhood location.

We first estimate the effects of voting laws for each age of exposure to suffrage in an event-study model. This allows us to visually inspect whether cohorts exposed at older ages, who we argue should be less affected by suffrage, have small treatment effects, and to show the pattern of treatment effects among children exposed at younger ages.

We estimate:

$$
Y_{i c s r t}=\alpha_{0}+\sum_{a=-10}^{30} \beta_{a}\left(\text { Age Treat } t_{c s}=a\right)+\gamma_{1} \prime X_{i c s t}+\gamma_{2} \prime Z_{c s}+\theta_{c}+\delta_{s}+\chi_{s} \times c+\tau_{c t}+\phi_{r c}+\epsilon_{i c s r t}
$$

where $i, c, s, r$, and $t$ represent individual, cohort, state of birth, region of birth, and survey

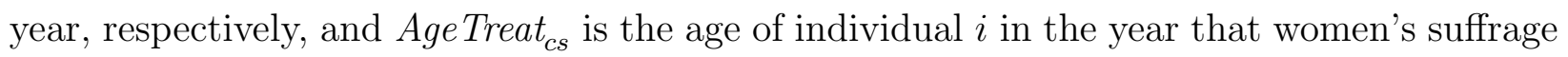
was passed in $s . \delta_{s}$ and $\theta_{c}$ flexibly control for differential political, education, and education climates across states and cohorts, respectively. A state-level trend, $\chi_{s} \times c$, controls for linear changes in education at the state level across different years of birth, and cohort

\footnotetext{
${ }^{13}$ We have also run the results requiring cities to appear in 8, 9, or 10 years or including cities that appear in fewer years. The results remain the same.

${ }^{14}$ Other sources of education spending begin many decades after suffrage, such as the Census of Governments (which begins in 1972) or the Historical Database on Individual Government Finances (which begins in 1967) (Jackson, Johnson and Persico, 2016).
} 
by survey year fixed effects, $\tau_{c t}$, further control for the aging of cohorts over time. We also include a vector of individual controls, $X_{i c s t}$, including race, age, and gender, and a vector of state-cohort controls, $Z_{c s}$, which includes state demographics, employment, wages, and education policies in the year of birth, $c$. Region by cohort fixed effects,f $\phi_{r c}$ control for unobservable differences across regions over time that may be related to the clustered passage of suffrage laws. ${ }^{15}$ The variation used for identification of the coefficients of interest, $\beta_{a}$, is thus generated by differential exposure to suffrage within cohorts and across states (within regions), as well as within states and across cohorts.

To increase power, we group together treated ages greater than or equal to 30 and treated ages less than or equal to -10 . We also group together pairs of consecutive ages of treatment, such that individuals treated at ages -10 and -9 are both assigned Age Treat $c_{c s}=-9$, individuals treated at ages -8 and -7 are both assigned Age Treat ${ }_{c s}=-7$, and so forth. ${ }^{16}$ All coefficients are measured relative to the omitted category, which is treatment at ages 16 or 17 . We perform regressions separately by race to take account of the marked gaps in educational attainment and in human capital investments across black and white children during this period.

We summarize the average effect of additional exposure to suffrage using a generalized difference-in-differences approach, as follows: ${ }^{17}$

$$
Y_{i c s r t}=\alpha_{0}+\beta_{1} \text { SuffExp015 } 5_{c s}+\gamma_{1} \prime X_{i c s t}+\gamma_{2} \prime Z_{c s}+\theta_{c}+\delta_{s}+\chi_{s} \times c+\tau_{c t}+\phi_{r c}+\epsilon_{i c s r t}
$$

where SuffExp015 $c$ is a continuous measure of exposure to the suffrage laws, defined as the share of time between birth and age 15 that women are able to vote in an individual's state of birth. ${ }^{18}$ We define the relevant age of exposure ending at the typical school-leaving age, 15 years, which we calculate as the sum of the median age of school entry (7) and average completed schooling (8) (Collins and Margo, 2006). However, since there is a wide

\footnotetext{
${ }^{15}$ Importantly, this helps control for important differences in education outcomes across regions (see Appendix Figure A.3.) When we exclude these fixed effects, the average effect for whites increases by four-fold, and the estimate becomes statistically significant - see Appendix Table A.2. Interestingly, the standard errors change very little when we include these fixed effects, though, which suggests that we are not losing excessive identifying variation.

${ }^{16}$ Grouping in this manner also allows us to estimate state trends and region by birth cohort fixed effects without dropping additional event-time dummies.

${ }^{17}$ Although we refer to this as the average effect, $\beta_{1}$ may not precisely correspond to the average treatment effect in the population due to uneven weighting across states (Goodman-Bacon, 2018; de Chaisemartin and D'Haultfoeuille, 2019; Borusyak and Jaravel, 2016). However, reassuringly, our results are similar across the difference-in-difference and our event studies, which are less susceptible to weighting issues (Goodman-Bacon, 2018).

${ }^{18}$ Formally,

$$
\text { SuffExp015 } \left.5_{c s}=\sum_{a=0}^{15} \frac{1(c+a>\text { YearSuffrage }}{s}\right)
$$

where YearSuffrage ${ }_{s}$ is the year in which suffrage was passed in the state.
} 
distribution of school entry and leaving ages, this is only a rough approximation, and we will use our event study specification as a data-driven way to validate the relevance of this margin.

\subsection{Identifying Assumptions and Testable Implications}

The identifying assumptions for this model are that (i) suffrage laws are not correlated with an unobserved trend in education outcomes across states, and that (ii) there are no confounding events with suffrage. We address assumption (i) in part by including linear state-specific trends to minimize the influence of unobserved trends. Nonetheless, there may remain some (potentially small) correlations with unobserved time-varying factors that remain threats to our identification.

We provide evidence of the plausibility of assumption (i) by testing whether suffrage was preceded by a systematic change in any of a number of state policies, demographics, or economic activity. To diagnose the importance of any pre-existing trend, we estimate a modified event-study model, in which we replace the pre-suffrage indicators with a linear trend, as follows:

$$
Y_{s t}=\alpha_{0}+\alpha_{1} \text { YearRelSuffrage }_{s t}+\sum_{y=-10}^{10} \beta_{y}\left(\text { YearRelSuffrage }_{s t}=y\right)+\gamma \prime Z_{s t}+\delta_{s}+\phi_{r t}+\epsilon_{s t}
$$

$Y_{s t}$ is a state- (or city-) characteristic in state (or city) $s$ and YearRelSuffrage st $_{\text {is a linear }}$ trend in years since suffrage in state $s$, and $\sum_{y=1}^{20}\left(\right.$ YearRelSuffrage $\left._{s t}=y\right)$ are indicators for each year after suffrage. The coefficient of interest is $\alpha_{1}$. Because we include indicators for each year after suffrage, $\alpha_{1}$ is mechanically only identified only from the data prior to suffrage, and therefore gives the slope of $Y_{\text {st }}$ over time prior to suffrage. We include state (or city) fixed effects, region by year fixed effects, and the same state time-varying controls as in Equation 2. ${ }^{19}$

To reduce noise in the estimation of the pre-trend $\left(\alpha_{1}\right)$, we estimate this using the sample of states (or cities) for which we have at least three years of data prior to suffrage. Thus, we analyze outcomes for 31 states for the majority of the state-level regressions, and for 2,129 cities across 41 states for the city-level regressions.

Table 1 shows our estimates of $\alpha_{1}$. Of the 19 outcomes we analyze, just four are significant at the 5 percent level: manufacturing wages per earner $\left(\alpha_{1}=0.02\right)$, doctors capita $\left(\alpha_{1}=\right.$ $0.04)$, white mortality under age $5\left(\alpha_{1}=-0.056\right)$, and log school enrollment $\left(\alpha_{1}=-0.01\right)$,

\footnotetext{
${ }^{19}$ We exclude any controls that are directly related to the outcome in order to increase our ability to detect a trend. To improve balance, we set YearRelSuffrage $=10$ for all years at least 10 years after suffrage, and YearRelSuffrage $=-10$ for all years at least 10 years before suffrage. For the city-level outcomes, we also group together -10 and $-9,-8$ and -7 , etc., since we only observe cities biennially.
} 
and. Moreover, the direction of bias from these is not obvious. For instance, the effect of a reduction in white mortality or more doctors per capita on education could be negative due to the presence of weak survivors, or positive due to health improvements. Similarly, higher manufacturing wages could reduce school attendance through the substitution effect, or increase attendance through improvements in family income. Last, the slight negative trend in school enrollment is most likely to bias us against finding an effect.

The remaining 15 coefficients are not significant, typically small in magnitude, and are not systematic in the predicted effects on human capital. Included in these 15 outcomes is a predicted education index for whites and blacks, which we create by regressing the mean education for state-cohort cells pre-suffrage on state covariates (shown in the table) in the year of birth, and then obtaining fitted values for all state-cohort observations. ${ }^{20}$ Regressions are run separately for whites and blacks. The trend in this index is highly insignificant ( $p=0.41$ for whites; $p=0.20$ for blacks). This is consistent with previous investigations that have shown few correlates of suffrage (Dahlin, Cornwall and King, 2005; Braun and Kvasnicka, 2013; Miller, 2008). Reinforcing this, in the next section we also find no trend in observed education across cohorts.

To complement this analysis, we also directly examine the correlations between the year of suffrage or whether a state passed suffrage in 1920 ("late") with pre-suffrage levels, presuffrage changes, and contemporaneous changes in state covariates. We do this for the set of states that passed suffrage after 1917 (as above) and the full set of states, and present the results in Appendix Tables A.3 and A.4, respectively. In 10 out of 11 specifications, we cannot reject the hypothesis that the covariates do not significantly predict the timing of suffrage.

One might also be worried that suffrage was bundled with other progressive era laws that could have improved education. Appendix Table A.5 finds no correlation between the year that suffrage was passed and the year of several other laws, including prohibition and women's minimum wage. Moreover, the direction of the coefficients indicate that, if anything, suffrage was typically passed after these laws, which means that any effect of these other laws would have been expected to show up in the pre-trends analysis. Similarly, the timing of suffrage could be associated with other infusions of spending, like during the New Deal, or contemporaneous changes in compulsory schooling laws. Again, we do not find evidence for this (see Appendix Tables A.6, A.7 and A.8).

\footnotetext{
${ }^{20}$ For state-year cells where we do not observe mortality, we use a prediction that omits mortality as a covariate.
} 


\section{Results}

We present the results for the event study specification separately by race in Figure 2, where we plot the estimated coefficients as well as their $95 \%$ confidence intervals by age of treatment.

For blacks, shown in Panel A, we find large, positive, and statistically significant effects for children that were exposed to suffrage prior to age 15. Further, younger exposure is generally associated with larger increases in education. Exposure to suffrage at ages 1215 leads to roughly a quarter of a year of additional education, while exposure to suffrage between the ages of 0-5 leads to around three-quarters of a year of education. However, we do not find any differential impact of exposure within the ages of 0 to 5 , suggesting that the effects are not driven by early-life exposure to suffrage. ${ }^{21}$ Importantly, we find no effect of suffrage on the education of those that were exposed to suffrage after age 15 . This is consistent with our hypothesis that the education of individuals who had already left school would be unaffected by the passage of suffrage.

In contrast, for whites shown in Panel B, the effects hover at zero and are flat at all ages of treatment. This is potentially consistent with prior evidence that resources may be less important for relatively more advantaged populations (Carruthers and Wanamaker, 2013, e.g.). In Section 5.1, we test whether there are varying impacts within whites and blacks to probe whether less-advantaged white populations benefited more from suffrage.

Across both samples, the pattern of the coefficients provides strong evidence in favor of our empirical strategy. The absence of an impact of suffrage among individuals exposed to suffrage after age 15 suggests that our effects are not capturing differential trends in educational attainment across cohorts. ${ }^{22}$ Additionally, the increasing and then flat the coefficients between the ages of 0 to 15 resembles the age-pattern of effects resulting from exposure to other important childhood interventions, such as increases in school spending and exposure to high-quality neighborhoods (Jackson, Johnson and Persico, 2016; Chetty and Hendren, 2018), which bolsters our confidence in these results.

We present the difference-in-differences estimates for all, whites, and blacks in columns (1)-(3) of Table 2. On average, full exposure to suffrage between the ages of 0 to 15 leads

\footnotetext{
${ }^{21}$ In Table A.9 we test the marginal effect of exposure to suffrage between ages 11-15, 6-10, and 0-5 using a spline in exposure to suffrage. We find that the impact of an additional year of suffrage exposure is roughly 0.1 between the ages 6-15, and that, conditional on exposure at later ages, the effects of exposure between ages $0-5$ has little additional impact on education outcomes.

${ }^{22}$ We formally test for an effect of suffrage beyond age fifteen in Appendix Table A.10 by including the effect of exposure between age 16 and 22 and between 23 and 30 as additional covariates in the regression. We find an insignificant effect of suffrage exposure after age 15, while the coefficient on exposure between age 0 and 15 is similar to our base specification.
} 
to a statistically insignificant 0.09 increase in years of schooling. Consistent with our event studies, for whites, full exposure to suffrage led to a statistically insignificant 0.06 year increase in education. For blacks, full exposure to suffrage led to 0.88 years of additional education $(\mathrm{p}<0.01)$. This effect is statistically-significantly larger than the effect on whites $(\mathrm{p}<0.045)$, and represents a $13 \%$ gain relative to the average years of completed education for blacks.

In the remaining four columns of Table 2 we analyze whether suffrage differentially improves outcomes for girls, a pattern shown in previous studies of female empowerment (Qian, 2008; Duflo, 2003; Beaman et al., 2012). This could occur if, for example, parents perceived daughters to be more valuable after suffrage, and therefore perceived the returns to investing in the human capital of daughters to be higher. Additionally, there may be changes in gender attitudes and modeling effects for younger girls inspired by women's expanded political rights.

Contrary to these predictions, we do not find larger impacts on the education of women. We find a statistically insignificant impact of suffrage for white women, and while the point estimate is larger than the impact for white men, we could not rule out that they are the same. For blacks, we actually find a larger effect of suffrage exposure on men than on women (1.26 years compared with 0.55 years). This is potentially a reflection of the fact that men had lower human capital investments at baseline - reflected in lower average levels of education - which could result in a higher returns to investment.

\subsection{Sources of Treatment Effect Heterogeneity}

The fact that we find larger impacts of suffrage for blacks is consistent either with (i) suffrage leading to particularly large changes in black communities, counter to historical narratives; or (ii) suffrage having a larger impact for communities with fewer resources. To distinguish between these explanations, we now examine whether suffrage had heterogeneous impacts by pre-suffrage education levels and within racial groups. ${ }^{23}$

Descriptively, Figure 3 plots the impact of suffrage for groups defined by region, race, and gender against the average level of education for each group prior to suffrage, which we measure using individuals who were at least age 16 at suffrage. It shows a clear negative relationship between the impact of suffrage and pre-suffrage education levels: groups that averaged 4 to 8 years of education pre-suffrage gained roughly one year of additional education post-suffrage, while groups that averaged 9 or more years education pre-suffrage experienced little or no gain.

\footnotetext{
${ }^{23}$ We find similar patterns using other measures of socioeconomic status (see Appendix Figure A.4.)
} 
Figure 3 also shows that the impacts of suffrage are present among low-educated whites, in addition to blacks. In particular, white children in the South, who averaged 8 years of education prior to suffrage, gained an additional 0.96 years in education (se: 0.47) following suffrage, and whites in the Northeast and West, who averaged 9.3 and 9.1 years of education prior to suffrage, gained an additional 0.54 (se: 0.21 ) and 0.27 (se: 0.17 ) years, respectively. ${ }^{24,25}$

Next, we formally estimate this relationship by adding to our baseline specification an interaction between suffrage exposure and the pre-suffrage average education in the state. We calculate pre-suffrage education separately for all, whites, and blacks.

Table 3 reports the the main effect of suffrage, i.e., the impact of suffrage for a group with zero pre-suffrage education, and the interaction with pre-suffrage interaction. For the whole sample, the coefficient on the main effect is 2.53 and the coefficient on the interaction is $-0.28(p<0.01)$. This implies that the effect of full exposure to suffrage goes down by 0.28 years with every additional year of pre-suffrage education for a group. ${ }^{26}$ Columns (2)-(3) of Table 3 shows a similar pattern within whites and blacks: the interaction with pre-suffrage education is -0.31 for whites $(p<0.01)$ and -0.17 for blacks $(p>0.10)$. These results are consistent with our hypothesis that the impact of suffrage was near-universal at low levels of education for both whites and blacks, but does not appear in the average effect for whites because of the higher level of education in that sample.

\subsection{Impacts on the Distribution of Education}

To gain a richer understanding of the effects on attainment, we employ distributional methods to identify the margin of educational attainment most impacted by suffrage. Specifically, estimate the effect of exposure to suffrage on one minus the cumulative distribution function of educational attainment (1-CDF) (Duflo, 2001). This gives the impact of suffrage on the probability of having a level of education greater than a particular threshold. In practice, we estimate a series of regressions where the outcome is an indicator for whether the completed education of individual $i$ is greater than $p$, where $p$ takes on the discrete values

\footnotetext{
${ }^{24}$ See Appendix Table A.11 for the coefficients estimated for each region and race. We are able to reject that the effects for whites across regions are the same $(p=0.07)$. For blacks, we can not reject that the effects are the same in all regions outside the West, which we exclude from the test due to concerns about small sample size and overfitting.

${ }^{25}$ Appendix Figure A.5 shows this in an event study by allowing for differential effects for white and black children from the South and non-South. The age pattern of effects for whites from the South is very similar to that of blacks, with larger gains for those exposed at younger ages, and leveling off for those exposed by age 5. But white children in the South exposed between the ages of 15 and 30 also experience some small increases in education.

${ }^{26}$ As a basic check on the fit of this model, we plug in the pre-suffrage mean education levels of whites and blacks, and obtain estimates close to our baseline difference-in-difference effects.
} 
from 0 to 17 (Almond, Hoynes and Schanzenbach, 2011; Duflo, 2001).

We plot the coefficients from this series of regressions in Panel A (for blacks) and Panel B (for whites) of Figure 4, together with distribution of educational outcomes pre-suffrage. For blacks, we find that the impact of suffrage on education attainment is concentrated between 4 and 9 years of education. For whites, we find small effects between 7 and 9 years of education. Relative to the baseline distributions, the impacts for both blacks and whites are clustered around the median for each group, which is 5 years for blacks and 8 years for whites. Thus, it appears that one of the main benefits of suffrage may have been to help raise the schooling of children who otherwise would have been at the bottom-to-middle of the education distribution.

\subsection{Literacy and Labor Market Outcomes}

The previous discussions focused on the impact of suffrage on the quantity of education attained. In this section, we examine whether the extended time in school led to the acquisition of literacy, and whether the impacts on education translated into gains in the labor market.

Literacy We analyze effects on literacy as a proxy for whether suffrage led to increases in measurable skills. Note, though, that since literacy was near-universal by the 1900 cohort, especially among whites, this measure will only pick up improvements in very basic abilities (Collins and Margo, 2006). ${ }^{27}$ Even with this little variation, Appendix Figure A.6 indicates that there were some positive impacts on literacy, with up to a 5 percentage point increase for black children exposed at the youngest ages. ${ }^{28}$ While these results are measured with error, this provides suggestive evidence that suffrage led to improvements in literacy together with extended schooling.

Labor Market Outcomes Next, we analyze whether suffrage impacted labor market outcomes, including the likelihood that an individual is employed (which we define as having non-zero wage earnings), real wage earnings (in 1960 dollars and including 0's), and the $\log$ of real wage earnings. ${ }^{29,30}$ Here we limit our sample to men and women between the

\footnotetext{
${ }^{27}$ Among the 1900 cohort, whites and blacks had literacy rates above $98 \%$ and $82 \%$, respectively (Collins and Margo, 2006).

${ }^{28}$ However, we note that there is a pre-trend in this outcome, which suggests that suffrage may have had spillover impacts to older groups, or may have been preceded by policies that improved the quality, but not quantity of schooling for older cohorts.

${ }^{29}$ For reference, $\$ 1$ in 1960 is the equivalent of $\$ 8.75$ in 2020 , according to the Bureau of Labor Statistics.

${ }^{30}$ We test the sensitivity of these results to dropping data from the 1940 census, which, unlike the other censuses, does not report the earnings of self-employed workers (Collins and Wanamaker, 2014), and find
} 
ages of 30 and 65. Motivated by the heterogeneity in our education analysis, we allow the effect of exposure to suffrage on labor outcomes to vary for individuals in the South and by pre-suffrage education.

Panel A of Table 4 shows that full exposure to suffrage for Southern whites led to a large and significant effect on log earnings (22 percent), and a positive effect on earnings $(\$ 170, p>0.10)$, with no impact on employment. ${ }^{31}$ We also find a significant effect on earnings for blacks outside the South $(\$ 464)$, along with large increases in employment (12.7 p.p.) However, for Southern blacks, we find an insignificant impact on employment and a marginally significant decline in earnings. The absence of labor market gains for this group is perhaps not entirely surprising - it is consistent with prior evidence of labor market discrimination or and the low quality of education for this group (Card and Krueger, 1992; Karbownik and Wray, 2019; Bhalotra and Venkataramani, 2015). ${ }^{32}$ The point estimates are noisy, though, and we can not rule out some small earnings gains.

In Panel B, we find that impacts on earnings levels are larger for whites from states with low average education pre-suffrage $(p<0.10)$. We also find that impacts on employment are suggestively larger for blacks from states with higher education, consistent with our larger effects for blacks from outside the South. These results reinforce our conclusions above: that suffrage-induced education gains led to improvements in labor market outcomes for many groups, but - importantly - not for Southern blacks.

\section{Mechanisms}

We interpret our education results as the reduced form effect of increased women's bargaining power and public spending, which could affect human capital through improvements in health and educational quality. In this section we explore which of these mechanisms, if any, could account for the larger impact of suffrage on the education of less-advantaged groups.

Mechanism 1: Bargaining First, political empowerment may increase the bargaining power of women in the household by reducing a woman's reliance on her husband. Our

similar results.

${ }^{31}$ We find no impact of suffrage exposure on labor market outcomes for whites outside the South, consistent with the absence of education gains for that group. For the event study figures for log income for whites, see Appendix Figure A.7.

${ }^{32}$ In Appendix Figure A.8 we show distributional effects on earnings by race and by South/non-South, using the same methodology as the distributional effects on education in Figure 4. It confirms the lack of effects for Southern blacks at any level of earnings, and indicates that impacts on earnings for Southern whites and blacks outside the South were concentrated around the median to $75^{\text {th }}$ percentile of earnings. 
evidence is weakest for this channel since we do not observe much of intra-household behavior, including spending. Nevertheless, while this channel may have contributed to the effects on white children, it is less plausible for disenfranchised black communities. Thus, while bargaining may be a contributing factor to our estimates, it is unlikely to be the only channel.

Mechanism 2: Health Improvements Second, to examine heterogeneous improvements in health, we regress the log of the number of infant mortalities in a state on an indicator for the years after suffrage together with our controls for state demographics and policies, state and year fixed effects, and state linear time trends. We do this separately for whites and blacks, and then test for interactions with South or pre-suffrage levels of education (determined by state and race, as previously.)

Appendix Table A.12 shows that suffrage led to declines in mortality, particularly for whites. Mortality improvements are larger in the South and for groups with lower presuffrage education. However, unlike our impacts on education, the mortality effects are small for blacks outside the South and significant for whites in the non-South $(p<0.05)$. In that sense, our impacts on education to not appear to be explained by improvements in mortality. ${ }^{33}$

In Appendix Table A.13, we perform a bounding exercise following Lee (2009) to examine the potential role of selection from infant mortality in our education estimates. In particular, we trim the top (bottom) of education outcomes to obtain the lower (upper) bound of the impact of suffrage. We obtain a lower bound that is similar to our main results, and an upper bound that is at least four times as large as our main estimates for both whites and blacks. This suggests that our baseline estimates, if anything, may be an underestimate of the true effects of suffrage accounting for selection.

Mechanism 3: Education Spending Third, we use our data on city-level spending, revenues and enrollment to examine dynamic impacts on education spending, revenue, and enrollment post-suffrage. We estimate:

$$
Y_{c a}=\alpha_{0}+\sum_{t=-5}^{7} \beta_{t}\left(\text { YearRelSuffrage }_{c a}=t\right)+\gamma \prime Z_{s a}+\delta_{c}+\phi_{a}+\epsilon_{c a}
$$

where $c$ and $a$ index city and academic year, respectively. YearRelSuffrage $e_{c a}=t$ is thus an indicator for $t$ academic years since suffrage. We pair together consecutive academic years to increase power, and omit the pair of years consisting of the year that was suffrage was

\footnotetext{
${ }^{33}$ However, there may be other unobserved improvements in health (e.g., reductions in the severity and duration of sickness spells) that could have contributed to increases in schooling attendance.
} 
passed and the preceding year. $Z_{s a}, \delta_{c}$ and $\phi_{a t}$ indicate state demographic controls, city and academic year fixed effects, respectively.

Table 5 examines average impacts on log expenditures (column 1), log total, local, and state revenue (columns 2-4), and school enrollment (column 5). Schooling expenditures post-suffrage increased by $3.4 \%$ within one year $(p>0.10)$, by $10.8 \%(p<0.05)$ within three years, and by $13.9 \%(p<0.05)$ within five years. Further, these effects persist for at least seven years post-suffrage. ${ }^{34,35}$ Suffrage also led to an 11 to 15 percent increase in revenue within the first seven years post-suffrage. This increase in revenue was driven primarily by increases in local revenue (city + county), with insignificant (and often negative) impacts on state revenue. Finally, we find positive but insignificant average effects on enrollment.

To examine heterogeneous effects of suffrage, we allow the estimated effect of suffrage on spending and enrollment to differ across three measures of "status" or "advantage." In particular, we allow the effect of suffrage to vary by (i) the average level of education in the state prior to suffrage (the same measure used in our earlier analysis); (ii) non-South; and (iii) black share of the city population in $1910 .{ }^{36}$

The left panels of Figure 5 present the implied effects of suffrage on log expenditures for cities in the $75^{\text {th }}$ and $25^{\text {th }}$ percentiles of pre-suffrage level of education (panel A) and share black (panel B), and for the South and non-South (panel C). We also show the difference between the $75^{\text {th }}$ and $25^{\text {th }}$ percentiles (panels A and B) or between the South and non-South (panel C). ${ }^{37}$ We find that both more- and less-advantaged cities experienced increases in log expenditures after suffrage. However, suggestively, areas with lower education, higher share black, and in the South appear to have experienced larger increases in spending. For example, our results imply that educational expenditures increased by 21 log points in the South within five years (23 percent), or roughly twice the 13 percent increase outside the South. ${ }^{38}$ The differences across areas are not typically statistically significantly different, but we may have less power due to the limited number of cities in our sample (and in each of these subgroups.)

The right panels of Figure 5 show that post-suffrage school enrollment follows a similar path as expenditures, with larger gains in cities with lower education, higher share black,

\footnotetext{
${ }^{34}$ We find comparable effects on expenditures per pupil.

${ }^{35}$ We note that funding increases of this magnitude were relatively common during this period, which had rapid growth in school funding. School revenues grew by at least $10 \%$ in over $50 \%$ of the consecutive years in our sample, indicating that funding levels were relatively malleable. See Appendix Table A.14.

${ }^{36}$ We thank Claudia Goldin for generously providing us with the data on black population used in Goldin and Katz (2010). We match these data to 233 cities in our sample.

${ }^{37}$ See Appendix Table A.15 for the individual coefficients.

${ }^{38}$ These estimated impacts on spending in the South are consistent with Carruthers and Wanamaker (2014), despite our different identification strategies, states in the analysis, and data sources.
} 
and in the South. We are able to reject that the difference in enrollment gains is zero for each of the measures of disadvantage. This aligns well with the pattern of gains in educational attainment we find in the Census.

In sum, we find a close link between increases in education spending, education enrollment, and completed education. We interpret this as evidence that changes in education spending post-suffrage were in all likelihood the primary channel for educational gains. We reinforce this intuition below by verifying that our effects could quantitatively be explained by the post-suffrage increases in education spending.

Pass-through to White and Black Schools Our results show that suffrage increased school spending at the city-level. To connect these effects to increases in education in the South, which was highly segregated, we next consider how much of this growth in city-level spending would have been "passed-through" to white and black schools (i.e., the elasticity of spending at black or white schools to city-level spending).

Since there are no existing estimates of pass-through (to our knowledge), we estimate this using county-level data from South Carolina and Georgia on education expenditures for white schools, black schools, and in total (Carruthers and Wanamaker, 2019, see Appendix B for details.) We regress log spending (or per-pupil spending) for white or black schools on log county spending (or per-pupil spending), together with county and year fixed effects. To focus on pass-through after suffrage, we estimate a separate coefficient on log county (per-pupil) expenditures after $1920 .^{39}$

The results shown in Appendix Tables A.16 and A.17 show that 10\% growth in county (per-pupil) funding leads to $10 \%$ (10\%) growth in county (per-pupil) spending for white schools, and $6.3 \%$ (5.1\%) growth in county (per-pupil) spending for black schools. ${ }^{40}$ Using the smaller estimates of pass-through, this implies that suffrage led to a 11.2 and 23 percent rise in spending in black and white schools in the South, respectively. Relative to the rest of the country, this places the percent rise in education spending for blacks in the South at the average percent growth outside of the South, and the percent rise in spending for white schools in the South substantially above the mean of the percent growth outside the South. This matches up with the patterns of education growth (which was higher for whites in the South relative to the non-South, and similar for blacks in the South and non-South.)

\footnotetext{
${ }^{39}$ In general, we find that pass-through to black schools increases after 1920, in contrast to Carruthers and Wanamaker (2014).

${ }^{40}$ The impacts on white and black schools do not average to one because in the data total spending is frequently larger than the sum of spending on white and black schools. We interpret this as reflecting administrative costs, although it may also be an error in transcription.
} 
Magnitude and Timing of Effects The up to one year increase in educational attainment from suffrage that we document is large, but aligns with other sizable education interventions. This effect is similar in magnitude to the impact of the Rosenwald school-building initiative (Aaronson and Mazumder, 2011) and court-ordered desegregation (Johnson, 2015). It is also not statistically distinguishable from the estimated impact of a $20 \%$ increase in per-pupil spending throughout schooling for children from poor families in Jackson, Johnson and Persico (2016) (0.92 years) and is within the bounds implied by the estimates in Hyman (2017) (0.043-1.04 years). ${ }^{41,42}$

Moreover, our impacts across groups fit with the previously-estimated effects of education spending. In particular, when we scale the average effect from Jackson, Johnson and Persico (2016) by our changes in education spending, we find that education spending could explain 110\%, 95\%, and $73 \%$ of our effects for Southern whites, Southern blacks, and blacks nationwide, respectively. ${ }^{43}$ This suggests that education spending is very likely to be the primary mechanism for our education effects.

The immediacy of the effects of suffrage on education funding and educational attainment is also not particular to suffrage. For instance, Cascio, Gordon and Reber (2013) and Gordon (2004) find that cities are able to adjust local education funding in 1 to 3 years in response to federal education grants. Further, Jackson, Johnson and Persico (2016) find that cohorts that benefited from any increase in spending show at least some evidence of improvements in education. This suggests that the education responses to spending following suffrage appear to be generalizable beyond this setting.

\section{Robustness}

In this section, we conduct a variety of robustness exercises to address potential concerns and alternative explanations for our estimates.

\footnotetext{
${ }^{41}$ See Table 3 of Jackson, Johnson and Persico (2016), which shows a 0.46 year increase in schooling for a $10 \%$ increase in spending. We obtain a comparable estimate from Hyman (2017), by applying the conversion from post-secondary enrollment to completed schooling described in that paper to the 4.3 p.p increase in post-secondary enrollment in low-income districts (Table 6.) We thus calculate that a $10 \%$ increase in spending leads to at most a 0.52 year increase in completed schooling $(0.043 \times 3 \times 4)$ and at least a 0.043 increase in completed schooling $(0.043 \times 1 \times 1)$.

${ }^{42}$ As another comparison, our effects are somewhat larger than the estimated impacts of compulsory schooling laws, which increased schooling between 0.04 and 0.4 years for white men (Stephens and Yang, 2014), but it is somewhat difficult to compare this regulation-style policy with the infusion of resources from suffrage.

${ }^{43}$ We calculate these by scaling the 0.92 effect from Jackson, Johnson and Persico (2016) by the change in spending for the group five years post suffrage as a fraction of $20 \%$, and dividing that by our estimated effect for the group. For Southern whites this is $\frac{23 \%}{20 \%} \times \frac{0.92}{0.96}=1.1$; for Southern blacks this is $\frac{23 \% \times 0.63}{20 \%} \times \frac{0.92}{0.7}=0.95$, taking account $63 \%$ pass-through; and for blacks on average this is $\frac{13.9 \%}{20 \%} \times \frac{0.92}{0.88}=0.73$.
} 
Mandatory States First, we check whether suffrage had an impact on education in states that were mandated to accept suffrage by the Nineteenth Amendment (i.e, who did not vote to ratify the Amendment.) This allows us to rule out the possibility that our effects are driven by endogenous adoption of suffrage laws. Panel A of Appendix Table A.18 shows that in fact suffrage had a larger effect on education in mandated states relative to voluntary states. Nevertheless, Panel B shows that our effects are also robust to dropping the mandatory states. Thus, the impact of suffrage does not appear to depend on how suffrage was adopted.

Randomization Test with Placebo Suffrage Laws Second, we perform a randomization test that allows us to determine whether our effects could have arisen by chance (Athey and Imbens, 2017). In particular, we randomly draw a placebo suffrage year between 1910 and 1920 for each state, and then assign placebo individual suffrage exposure based on that placebo year. We then use Equation 2 to estimate the effect of placebo suffrage exposure on educational attainment, separately for blacks and whites. We repeat this 1000 times. Consistent with our main results, this test produces a p-value below 0.01 for the impacts of suffrage on blacks' education and a p-value of 0.31 for the impacts of suffrage on whites' education (see Appendix Figure A.9.)

Migration by Parents or Children Third, we consider the potential role of migration by parents (pre-birth) or by children (post-birth) in our results. The fact that we found little change in state demographics following suffrage in Section 4.1 provides evidence against selective migration by parents. To examine the role of child migration, we stratify our results by individuals that remain in the same state of birth ("non-movers") or not ("non-movers"). We find that our effects are concentrated among non-movers (see Appendix Table A.19.) Thus, it does not appear that education gains following suffrage were a result of migration.

World War II and the G.I. bill Fourth, we check whether exposure to suffrage might be correlated with the likelihood of serving in World War II and, hence, with eligibility for the G.I. bill. Controlling for region fixed effects, we find no correlation between the year of suffrage and the proportion of the state serving in World War II (which we obtain from Acemoglu, Autor and Lyle, 2004). ${ }^{44}$

\footnotetext{
${ }^{44}$ Early cohorts in our sample born from 1880 to 1900 were also eligible to serve in WWI. Since these cohorts are concentrated among our "control group", we can look for evidence of bias from the War in the form of pre-trend for the children too old to experience the benefits of suffrage. Our event studies show no evidence of this, however, indicating that any effect of the War is absorbed by our control variables.
} 
Additional checks Finally, we run a variety of additional specifications to verify the robustness of the results. These include trying alternative sample restrictions, e.g,: examining results by census year (Appendix Table A.20); keeping states that passed suffrage prior to 1900 (Appendix Table A.21); only keeping individuals over 25 (Appendix Table A.22); or restricting the sample to a smaller range of treatment ages (Appendix Figure A.10). They also include testing alternative measures of treatment and controls, e.g.,: running a model with a binary measure of exposure to suffrage (Appendix Table A.23); substituting our baseline state controls (measured at birth) with average state conditions between ages 0-15 or an interaction between state conditions in 1900 with a linear trend (Appendix Table A.24, Panels A-C); dropping compulsory law controls, allowing the effect of compulsory laws to vary by age, adding controls for progressive laws, controlling for trends interacted with the pre-suffrage education level of the state, and dropping states that had Rosenwald school (Appendix Table A.24, Panels D-H). Our conclusions do not change across any of these specifications.

\section{Conclusion}

This paper presents new evidence on the effects of women's political empowerment on children's human capital. We find that exposure to suffrage during childhood led to substantial gains in educational attainment, particularly for children from economically disadvantaged backgrounds. Full exposure to suffrage between the ages of 0 and 15 increased educational attainment by slightly less than one year for black children and white children from the South, who had the lowest levels of education pre-suffrage. We also provide new evidence that suffrage led to disparate increases in education spending across the country. These increases in spending appear to explain our heterogeneous impacts on education.

On the whole, this article provides compelling evidence for the role of female voter preferences in influencing policy, both towards greater investments in children and less advantaged groups. As political power increasingly equates to economic holdings, a future promising avenue for research is to understand whether women's economic power can lead to similar gains. This question is of great relevance today given the push for gender equality in the workplace. We leave it for future research to provide evidence in this area. 


\section{References}

Aaronson, Daniel, and Bhashkar Mazumder. 2011. "The Impact of Rosenwald Schools on Black Achievement." Journal of Political Economy, 119(5): 821-888.

Acemoglu, Daron, and Joshua Angrist. 2000. "How Large are Human-Capital Externalities? Evidence from Compulsory-Schooling Laws." NBER Macroeconomics Annual 2000, 15: 9-74.

Acemoglu, Daron, David H. Autor, and David Lyle. 2004. "Women, War, and Wages: The Effect of Female Labor Supply on the Wage Structure at Midcentury." Journal of Political Economy, 112(3): 497-551.

Aidt, Toke S., and Bianca Dallal. 2008. "Female Voting Power: The Contribution of Women's Suffrage to the Growth of Social Spending in Western Europe (1869-1960)." Public Choice, 134(3-4): 391-417.

Alesina, Alberto, and Paola Giuliano. 2011. "Preferences for redistribution." In Handbook of social economics. Vol. 1, 93-131. Elsevier.

Almond, Douglas, Hilary W. Hoynes, and Diane Whitmore Schanzenbach. 2011. "Inside the War on Poverty: The Impact of Food Stamps on Birth Outcomes." Review of Economics and Statistics, 93(2): 387-403.

Andreoni, James, and Lise Vesterlund. 2001. "Which is the Fair Sex? Gender Differences in Altruism." The Quarterly Journal of Economics, 116(1): 293-312.

Ashok, Vivekinan, Ilyana Kuziemko, and Ebonya Washington. 2015. "Support for Redistribution in an Age of Rising Inequality: New Stylized Facts and Some Tentative Explanations." Brookings Papers on Economic Activity.

Athey, Susan, and Guido W Imbens. 2017. "The Econometrics of Randomized Experimentsa." In Handbook of Economic Field Experiments. Vol. 1, 73-140. Elsevier.

Baker, Paula. 1984. "The Domestication of Politics: Women and American Political Society, 1780-1920." The American Historical Review, 89(3): pp. 620-647.

Beaman, Lori, Esther Duflo, Rohini Pande, and Petia Topalova. 2012. "Female leadership raises aspirations and educational attainment for girls: A policy experiment in India." science, 1212382. 
Benson, Charles S., and Kevin O'Halloran. 1987. "The Economic History of School Finance in the United States." Journal of Education Finance, 12(4): 495-515.

Bhalotra, Sonia R, and Atheendar Venkataramani. 2015. "Shadows of the Captain of the Men of Death: Health Innovation, Human Capital Investment, and Institutions." Working Paper.

Borusyak, Kirill, and Xavier Jaravel. 2016. "Revisiting Event Study Designs."

Braun, Sebastian, and Michael Kvasnicka. 2013. "Men, Women, and the Ballot: Gender Imbalances and Suffrage Extensions in the United States." Explorations in Economic History, 50(3): 405-426.

Card, David E, and Alan B Krueger. 1992. "School Quality and Black-White Relative Earnings: A Direct Assessment." The Quarterly Journal of Economics, 107(1): 151-200.

Carruthers, Celeste K., and Marianne H. Wanamaker. 2013. "Closing the Gap? The Effect of Private Philanthropy on the Provision of African-American Schooling in the U.S. South." Journal of Public Economics, 101: 53-67.

Carruthers, Celeste K., and Marianne H. Wanamaker. 2014. "Municipal Housekeeping: The Impact of Women's Suffrage on the Provision of Public Education." Journal of Human Resources.

Carruthers, Celeste K., and Marianne H. Wanamaker. 2019. "County-level school enrollment and resources in ten segregated Southern states, 1910-1940."

Cascio, Elizabeth U, and Ebonya Washington. 2013. "Valuing the Vote: The Redistribution of Voting Rights and State Funds Following the Voting Rights Act of 1965*." The Quarterly Journal of Economics, 379-433.

Cascio, Elizabeth U., Nora Gordon, and Sarah Reber. 2013. "Local Responses to Federal Grants: Evidence from the Introduction of Title I in the South." American Economic Journal: Economic Policy, 5(3): 126-59.

Chattopadhyay, Raghabendra, and Esther Duflo. 2004. "Women as Policy Makers: Evidence from a Randomized Policy Experiment in India." Econometrica, 72(5): 14091443.

Chetty, Raj, and Nathaniel Hendren. 2018. "The Impacts of Neighborhoods on Intergenerational Mobility I: Childhood Exposure Effects*." The Quarterly Journal of Economics, 133(3): 1107-1162. 
Clots-Figueras, Irma. 2012. "Are Female Leaders Good for Education? Evidence from India." American Economic Journal: Applied Economics, 4(1): 212-44.

Clubb, Jerome M., William H. Flanigan, and Nancy H. Zingale. 2006. "Electoral Data for Counties in the United States: Presidential and Congressional Races, 1840-1972."

Collins, William J, and Marianne H Wanamaker. 2014. "Selection and economic gains in the great migration of African Americans: new evidence from linked census data." American Economic Journal: Applied Economics, 6(1): 220-52.

Collins, William J., and Robert A. Margo. 2006. "Chapter 3 Historical Perspectives on Racial Differences in Schooling in the United States." In Handbook of the Economics of Education. Vol. 1, , ed. E. Hanushek and F. Welch, 107-154. Elsevier.

Corder, J. Kevin, and Christina Wolbrecht. 2016. Counting Women's Ballots: Female Voters from Suffrage through New Deal. Cambridge University Press.

Croson, Rachel, and Uri Gneezy. 2009. "Gender Differences in Preferences." Journal of Economic Literature, 47(2): 448-474.

Dahlin, Eric C., Marie Cornwall, and Brayden G. King. 2005. "Winning Woman Suffrage One Step at a Time: Social Movements and the Logic of the Legislative Process." Social Forces, 83(3): 1211-1234.

de Chaisemartin, Clment, and Xavier D'Haultfoeuille. 2019. "Two-way Fixed Effects Estimators with Heterogeneous Treatment Effects." National Bureau of Economic Research Working Paper 25904.

Depew, Briggs, Griffin Edwards, and Emily Owens. 2013. "Alcohol Prohibition and Infant Mortality." Mimeo.

Duflo, Esther. 2001. "Schooling and Labor Market Consequences of School Construction in Indonesia: Evidence from an Unusual Policy Experiment." American Economic Review, 91(4): 795-813.

Duflo, Esther. 2003. "Grandmothers and Granddaughters: Old-Age Pensions and Intrahousehold Allocation in South Africa." The World Bank Economic Review, 17(1): 1-25. 00886 .

Duflo, Esther. 2012. "Women Empowerment and Economic Development." Journal of Economic Literature, 50(4): 1051-1079. 
Ferreira, Fernando, and Joseph Gyourko. 2014. "Does Gender Matter for Political Leadership? The case of U.S. mayors." Journal of Public Economics, 112: 24-39.

Fishback, Price V., Michael R. Haines, and Shawn Kantor. 2007. "Births, Deaths, and New Deal Relief during the Great Depression." Review of Economics and Statistics, 89(1): 1-14.

Goldin, Claudia, and Lawrence F. Katz. 2010. The Race between Education and Technology. Cambridge, Mass.:Belknap Press.

Goldin, Claudia, and Lawrence Katz. 2003. "Mass Secondary Schooling and the State." National Bureau of Economic Research Working Paper 10075.

Goodman-Bacon, Andrew. 2018. "Difference-in-Differences with Variation in Treatment Timing." National Bureau of Economic Research Working Paper 25018.

Gordon, Nora. 2004. "Do federal grants boost school spending? Evidence from Title I." Journal of Public Economics, 88(9): 1771 - 1792.

Haines, Michael R., and Inter-university Consortium for Political and Social Research. 2010. "Historical, Demographic, Economic, and Social Data: The United States, 1790-2002."

Hyman, Joshua. 2017. "Does Money Matter in the Long Run? Effects of School Spending on Educational Attainment." American Economic Journal: Economic Policy, 9(4): 25680 .

Jackson, C. Kirabo, Rucker C. Johnson, and Claudia Persico. 2016. "The Effects of School Spending on Educational and Economic Outcomes: Evidence from School Finance Reforms." The Quarterly Journal of Economics, 131(1): 157-218.

Johnson, Rucker C. 2015. "Long-run Impacts of School Desegregation \& School Quality on Adult Attainments." National Bureau of Economic Research Working Paper 16664.

Kantor, Shawn Everett, and Price V. Fishback. 1996. "Precautionary Saving, Insurance, and the Origins of Workers' Compensation." Journal of Political Economy, 104(2): 419-442.

Karbownik, Krzysztof, and Anthony Wray. 2019. "Long-Run Consequences of Exposure to Natural Disasters." Journal of Labor Economics, 37(3): 949-1007.

Keyssar, Alexander. 2000. The Right to Vote. Basic Books. 
Lafortune, Julien, Jesse Rothstein, and Diane Whitmore Schanzenbach. 2018. "School Finance Reform and the Distribution of Student Achievement." American Economic Journal: Applied Economics, 10(2): 1-26.

Lee, David S. 2009. "Training, Wages, and Sample Selection: Estimating Sharp Bounds on Treatment Effects." The Review of Economic Studies, 76(3): 1071-1102.

Lemons, J. Stanley. 1973. The Woman Citizen: Social Feminism in the 1920s. . First Edition edition ed., University of Illinois Press.

Lewis, Jeffrey B., Keith Poole, Howard Rosenthal, Adam Boche, Aaron Rudkin, and Luke Sonne. 2019. "Voteview: Congressional Roll-Call Votes Database. ."

Lleras-Muney, Adriana. 2002. "Were Compulsory Attendance and Child Labor Laws Effective? An Analysis from 1915 to 1939." Journal of Law and Economics, 45(2): 40135.

Lott, John R., and Lawrence W. Kenny. 1999. "Did Women's Suffrage Change the Size and Scope of Government?" Journal of Political Economy, 107(6): 1163-1198.

Lundberg, Shelly J, Robert A Pollak, and Terence J Wales. 1997. "Do husbands and wives pool their resources? Evidence from the United Kingdom child benefit." Journal of Human resources, 463-480.

Miller, Grant. 2008. "Women's Suffrage, Political Responsiveness, and Child Survival in American History." The Quarterly Journal of Economics, 123(3): 1287-1327.

Moehling, Carolyn M., and Melissa A. Thomasson. 2012. "The Political Economy of Saving Mothers and Babies: The Politics of State Participation in the Sheppard-Towner Program." The Journal of Economic History, 72(01): 75-103.

Morgan-Collins, Mona. 2019. "The Electoral Impact of Newly Enfranchised Groups: The Case of Womens Suffrage in the United States." Journal of Politics.

Naidu, Suresh. 2012. "Suffrage, Schooling, and Sorting in the Post-Bellum U.S. South." National Bureau of Economic Research Working Paper 18129.

Obama, Barack. 2010. "Presidential Proclamation." Presidential Proclamation - Women's Equality Day, 2013. 
Qian, Nancy. 2008. "Missing Women and the Price of Tea in China: The Effect of SexSpecific Earnings on Sex Imbalance." The Quarterly Journal of Economics, 123(3): 12511285. 00219.

Ruggles, Steven, Sarah Flood, Ronald Goeken, Josiah Grover, Erin Meyer, Jose Pacas, , and Matthew Sobek. 2020. "Integrated Public Use Microdata Series: Version 10.0 [Machine-readable database]."

Schuyler, Lorraine Gates. 2006. The Weight of Their Votes. University of North Carolina Press.

Skocpol, Theda. 1992. Protecting Soldiers and Mothers: The Political Origins of Social Policy in United States. Harvard:Belknap Press.

Stephens, Jr., Melvin, and Dou-Yan Yang. 2014. "Compulsory Education and the Benefits of Schooling." American Economic Review, 104(6): 1777-92.

Teele, Dawn L. 2018. Forging the Franchise. Princeton University Press.

Walker, Melissa, Jeanette R. Dunn, and Joe P. Dunn. 2003. Southern Women at the Millennium: A Historical Perspective. University of Missouri Press.

Youmans, Theodora W. 1921. "How Wisconsin Women Won the Ballot." The Wisconsin Magazine of History, 5(1): 3-32. 


\section{Tables}

\section{Table 1: Trend in State and City Characteristics Prior to Suffrage}

\begin{tabular}{lccccc}
\hline \hline & Trend coef. & SE & P-value & Observs & N States \\
\hline Pct. White & 0.253 & 0.282 & 0.377 & 357 & 31 \\
Pct. Urban & -0.292 & 0.515 & 0.575 & 357 & 31 \\
Pct. Foreign & 0.229 & 0.147 & 0.131 & 357 & 31 \\
Ln Pop & -0.006 & 0.015 & 0.713 & 357 & 31 \\
Pct. Emp. Manuf. & -0.001 & 0.002 & 0.598 & 357 & 31 \\
Ln Manuf. Wage per Earner & 0.022 & 0.010 & 0.039 & 357 & 31 \\
Ln Avg. Farm Value & 0.006 & 0.032 & 0.854 & 357 & 31 \\
Ln Tax-Reported Income per Capita & 0.095 & 0.065 & 0.153 & 357 & 31 \\
Ln Number Hospitals & -0.053 & 0.043 & 0.229 & 357 & 31 \\
Ln Doctors per Capita & 0.040 & 0.011 & 0.001 & 357 & 31 \\
Ln Mortality - Whites Ages 0-5 & -0.056 & 0.024 & 0.027 & 294 & 30 \\
Ln Mortality - Blacks Ages 0-5 & -0.064 & 0.074 & 0.395 & 283 & 29 \\
Ln Number of Schools per Capita & -0.052 & 0.052 & 0.327 & 357 & 31 \\
Compulsory Attendance & -0.097 & 0.294 & 0.744 & 357 & 31 \\
Schooling for Child Labor & -0.566 & 0.366 & 0.132 & 357 & 31 \\
Pred Yrs Ed - Whites (Summary Index) & -0.051 & 0.061 & 0.410 & 357 & 31 \\
Pred Yrs Ed - Blacks (Summary Index) & -0.074 & 0.057 & 0.203 & 320 & 31 \\
Ln School Enrollment (City Data) & -0.009 & 0.003 & 0.009 & 2357 & 41 \\
Ln School Spending (City Data) & 0.000 & 0.010 & 0.972 & 2357 & 41 \\
\hline \hline
\end{tabular}

Notes: This table presents results from 19 regressions where the outcome is shown in the first column, and the key coefficient of interest is on a trend in the number of years since suffrage. The regressions also include indicators for each year after suffrage, region-year fixed effects, state (or city) fixed effects, and state-year controls. Importantly, because we include indicators for each year after suffrage, the coefficient on the trend (shown in column 1) is identified only from pre-suffrage years, and therefore the p-value in column 3 can be interpreted as a test for whether there is a significant pre-trend for each outcome. "Pred Yrs Ed" is an education index generated by regressing the mean education for state-cohort cells pre-suffrage on state covariates (shown in the table) in the year of birth, and then obtaining fitted values for all state-cohort observations (separately for whites and blacks). For state-year cells where we do not observe mortality, we use a prediction that omits mortality as a covariate. The sample for each regression includes all states (or cities) for which we have at least three years of data prior to the passage of suffrage. Estimates are weighted using state (or city) population weights and standard errors are clustered at the state level. Sources: State characteristics from 1915 to 1930 are taken from Lleras-Muney (2002); infant mortality records from 1900 to 1930 are digitized from the Centers for Disease Control and Prevention; and records on city-level education spending are digitized from the 1909 to 1911 and 1913 to 1915 Report of the Commissioner of Education and the 1917 to 1927 Biennial Survey of Education for cities with populations of 10,000 and over. 
Table 2: Long-Run Effect of Suffrage Exposure on Years of Education

\begin{tabular}{|c|c|c|c|c|c|c|c|}
\hline & \multirow[b]{2}{*}{ All } & \multirow[b]{2}{*}{ Whites } & \multirow[b]{2}{*}{ Blacks } & \multicolumn{2}{|c|}{ Whites } & \multicolumn{2}{|c|}{ Blacks } \\
\hline & & & & Males & Females & Males & Females \\
\hline \multirow[t]{2}{*}{ Suff Share 0-15 } & 0.091 & 0.062 & $0.884^{* * *}$ & 0.027 & 0.092 & $1.259^{*}$ & $0.551^{* *}$ \\
\hline & $(0.203)$ & $(0.197)$ & $(0.295)$ & $(0.189)$ & $(0.221)$ & $(0.693)$ & $(0.270)$ \\
\hline Mean Education & 9.647 & 9.967 & 6.810 & 9.850 & 10.078 & 6.400 & 7.171 \\
\hline Observations & 1555475 & 1393855 & 157028 & 688363 & 705492 & 74351 & 82677 \\
\hline
\end{tabular}

Notes: This table presents results from regressions of completed years of education on suffrage exposure between ages $0-15$ (the share of time between birth and age 15 that an individual was exposed to a suffrage law in his state of birth.) We are able to reject that the coefficients for the white and black coefficients are the same $(p<0.045)$. All regressions include controls for demographics and state-level characteristics, birth state and birth year fixed effects, birth state linear time trends, as well as regionby-birth year and census year-by-birth year fixed effects. Estimates are weighted using Census sample weights, and standard errors are clustered on the state of birth. The sample consists of individuals born between 1880 and 1930, and that are at least 20 years old at the time of observation. We exclude states that passed suffrage prior to 1900 . Source: $1940-1960$ decennial censuses. ${ }^{*} \mathrm{p}<0.10,{ }^{* *} \mathrm{p}<0.05,{ }^{* * *}$ $\mathrm{p}<0.01$. 
Table 3: Long-Run Effect of Suffrage Exposure on Years of Education Interaction with Pre-Suffrage Education by State

\begin{tabular}{lccc}
\hline \hline & All & Whites & Blacks \\
\hline Suff Share 0-15 & $2.532^{* * *}$ & $2.794^{* * *}$ & $1.948^{*}$ \\
& $(0.600)$ & $(0.665)$ & $(1.123)$ \\
Suffrage Share 0-15 x Pre-Period Education & $-0.278^{* * *}$ & $-0.305^{* * *}$ & -0.166 \\
& $(0.065)$ & $(0.071)$ & $(0.166)$ \\
\hline Mean Education & 9.647 & 9.967 & 6.810 \\
Observations & 1555475 & 1393855 & 157024 \\
\hline \hline
\end{tabular}

Notes: This table presents results from regressions of completed years of education on suffrage exposure between the ages of $0-15$ and the interactions between suffrage exposure and average pre-suffrage education in each state (and race for columns (2) and (3).) Pre-suffrage average education is calculated using individuals who were are least age 16 in the year that suffrage was passed. All regressions include controls for demographics and state-level characteristics, birth state and birth year fixed effects, birth state linear time trends, as well as region-by-birth year and census year-by-birth year fixed effects. Estimates are weighted using Census sample weights, and standard errors are clustered on the state of birth. The sample consists of individuals born between 1880 and 1930, and that are at least 20 years old at the time of observation. We exclude states that passed suffrage prior to 1900. Source: 1940-1960 decennial censuses. ${ }^{*} \mathrm{p}<0.10, * * \mathrm{p}<0.05, * * * \mathrm{p}<0.01$. 


\section{Table 4: Long-Run Effect of Suffrage Exposure on Labor Market Outcomes -}

Interaction with South and Pre-Suffrage Education

\begin{tabular}{|c|c|c|c|c|c|c|}
\hline & \multicolumn{3}{|c|}{ Whites } & \multicolumn{3}{|c|}{ Blacks } \\
\hline & Earnings $>0$ & Earnings & Ln(Earnings) & Earnings $>0$ & Earnings & Ln(Earnings) \\
\hline \multicolumn{7}{|l|}{ A: Interaction with South } \\
\hline Suff Share 0-15 x Non-South & $\begin{array}{l}-0.001 \\
(0.008)\end{array}$ & $\begin{array}{c}-0.049 \\
(62.244)\end{array}$ & $\begin{array}{c}0.044 \\
(0.028)\end{array}$ & $\begin{array}{l}0.127^{* *} \\
(0.051)\end{array}$ & $\begin{array}{c}464.290^{* * *} \\
(105.829)\end{array}$ & $\begin{array}{c}0.178 \\
(0.112)\end{array}$ \\
\hline Suff Share 0-15 x South & $\begin{array}{l}-0.029 \\
(0.041)\end{array}$ & $\begin{array}{c}171.504 \\
(183.668)\end{array}$ & $\begin{array}{c}0.220^{* * * *} \\
(0.066)\end{array}$ & $\begin{array}{l}-0.041 \\
(0.082)\end{array}$ & $\begin{array}{l}-211.774^{*} \\
(125.735)\end{array}$ & $\begin{array}{c}-0.118 \\
(0.138)\end{array}$ \\
\hline Mean Y & 0.539 & 2040.533 & 7.866 & 0.618 & 1131.662 & 7.032 \\
\hline Observations & 1053059 & 1053059 & 574210 & 117665 & 117665 & 72415 \\
\hline \multicolumn{7}{|l|}{ B: Interaction with Pre-Period Education } \\
\hline $\begin{array}{l}\text { Suff Share } 0-15 \\
\text { S }\end{array}$ & $\begin{array}{c}0.129 \\
(0.084)\end{array}$ & $\begin{array}{l}875.571^{* *} \\
(409.932)\end{array}$ & $\begin{array}{c}0.057 \\
(0.262)\end{array}$ & $\begin{array}{c}-0.231 \\
(0.188)\end{array}$ & $\begin{array}{c}-248.694 \\
(300.492)\end{array}$ & $\begin{array}{c}0.064 \\
(0.249)\end{array}$ \\
\hline Suff Share 0-15 x Pre-Period Education & $\begin{array}{c}-0.015 \\
(0.009) \\
\end{array}$ & $\begin{array}{l}-96.118^{*} \\
(48.222) \\
\end{array}$ & $\begin{array}{c}0.000 \\
(0.029)\end{array}$ & $\begin{array}{c}0.041^{*} \\
(0.024)\end{array}$ & $\begin{array}{c}53.515 \\
(42.978) \\
\end{array}$ & $\begin{array}{c}-0.007 \\
(0.038)\end{array}$ \\
\hline Mean Y & 0.539 & 2040.533 & 7.866 & 0.618 & 1131.665 & 7.032 \\
\hline Observations & 1053059 & 1053059 & 574210 & 117663 & 117663 & 72413 \\
\hline
\end{tabular}

Notes: This table presents results from regressions of an indicator for having positive wage earnings (columns 1 and 4), real wage earnings (including 0's), $\$ 1960$ (columns 2 and 5), and log real earnings on either (i) suffrage exposure between ages 0-15 interacted with an indicator for non-South and an indicator for South (Panel A) or (ii) suffrage exposure between ages $0-15$ and the interaction between suffrage exposure and pre-suffrage average education in each state (Panel B). Pre-suffrage average education is calculated using individuals who were are least age 16 in the year that suffrage was passed. For reference, $\$ 1$ in 1960 is the equivalent of $\$ 8.75$ in 2020 . All regressions include controls for demographics and state-level characteristics, birth state and birth year fixed effects, birth state linear time trends, as well as region-by-birth year and census year-by-birth year fixed effects. Estimates are weighted using Census sample weights, and standard errors are clustered on the state of birth. The sample consists of individuals born between 1880 and 1930, and that are at between 30 and 60 years old at the time of observation. We exclude states that passed suffrage prior to 1900. Source: 1940-1960 decennial censuses. ${ }^{*} \mathrm{p}<0.10,{ }^{* *} \mathrm{p}<0.05,{ }^{* * *} \mathrm{p}<0.01$. 
Table 5: Short-run Effect of Suffrage on Log Education Expenditures, Log Enrollment, and Log Tax Revenues

\begin{tabular}{|c|c|c|c|c|c|}
\hline & \multirow[b]{2}{*}{ Expenditures } & \multicolumn{3}{|c|}{ Tax Revenues } & \multirow[b]{2}{*}{ Enrollment } \\
\hline & & Total & State & Local & \\
\hline \multicolumn{6}{|l|}{ Years Relative to Suffrage } \\
\hline $5+$ Years Prior & $\begin{array}{c}-0.083^{*} \\
(0.047)\end{array}$ & $\begin{array}{c}-0.090 \\
(0.058)\end{array}$ & $\begin{array}{l}-0.132 \\
(0.222)\end{array}$ & $\begin{array}{c}-0.116 \\
(0.072)\end{array}$ & $\begin{array}{c}0.006 \\
(0.036)\end{array}$ \\
\hline 3-4 Years Prior & $\begin{array}{l}-0.025 \\
(0.017)\end{array}$ & $\begin{array}{l}-0.027 \\
(0.031)\end{array}$ & $\begin{array}{l}-0.207 \\
(0.157)\end{array}$ & $\begin{array}{l}-0.019 \\
(0.038)\end{array}$ & $\begin{array}{c}0.001 \\
(0.014)\end{array}$ \\
\hline 0-1 Years After & $\begin{array}{c}0.034 \\
(0.022)\end{array}$ & $\begin{array}{c}0.032 \\
(0.025)\end{array}$ & $\begin{array}{l}-0.168 \\
(0.122)\end{array}$ & $\begin{array}{c}0.046 \\
(0.032)\end{array}$ & $\begin{array}{l}0.022^{*} \\
(0.012)\end{array}$ \\
\hline 2-3 Years After & $\begin{array}{c}0.108^{* * *} \\
(0.032)\end{array}$ & $\begin{array}{c}0.107^{* * *} \\
(0.038)\end{array}$ & $\begin{array}{l}-0.051 \\
(0.203)\end{array}$ & $\begin{array}{l}0.112^{* *} \\
(0.045)\end{array}$ & $\begin{array}{l}0.025 \\
(0.020)\end{array}$ \\
\hline 4-5 Years After & $\begin{array}{c}0.139^{* * *} \\
(0.038)\end{array}$ & $\begin{array}{c}0.154^{* * *} \\
(0.049)\end{array}$ & $\begin{array}{l}-0.262 \\
(0.316)\end{array}$ & $\begin{array}{l}0.168^{* *} \\
(0.065)\end{array}$ & $\begin{array}{c}0.031 \\
(0.024)\end{array}$ \\
\hline $6+$ Years After & $\begin{array}{c}0.135^{* * *} \\
(0.045)\end{array}$ & $\begin{array}{l}0.148^{* *} \\
(0.057)\end{array}$ & $\begin{array}{l}-0.086 \\
(0.371)\end{array}$ & $\begin{array}{c}0.128 \\
(0.099)\end{array}$ & $\begin{array}{c}0.044 \\
(0.033)\end{array}$ \\
\hline Observations & 5183 & 5183 & 4565 & 5172 & 5183 \\
\hline Pre Y Mean & 13.52 & 13.62 & 11.37 & 13.46 & 9.40 \\
\hline N States & 42 & 42 & 41 & 42 & 42 \\
\hline N Cities & 523 & 523 & 521 & 523 & 523 \\
\hline $\mathrm{N}$ Cities in NE & 232 & 232 & 232 & 232 & 232 \\
\hline $\mathrm{N}$ Cities in MW & 177 & 177 & 177 & 177 & 177 \\
\hline $\mathrm{N}$ Cities in $\mathrm{S}$ & 87 & 87 & 86 & 87 & 87 \\
\hline $\mathrm{N}$ Cities in $\mathrm{W}$ & 27 & 27 & 26 & 27 & 27 \\
\hline
\end{tabular}

Notes: This table presents results from regressions where the outcome is either log city schooling expenditures (column 1), log total revenue (total, from the state, or from local sources (city + county); columns 2-4), or log enrollment, and the key variables of interest are are indicators for the number of academic years since suffrage. All regressions include controls for state-level characteristics, and city and academic year fixed effects. Estimates are weighted using city population in 1910, and standard errors are clustered on state. The sample consists of all cities with available expenditure, revenue and enrollment data, which we observe for at least 7 years, and which are not outliers. Source: 1909 to 1911 and 1913 to 1915 Report of the Commissioner of Education, and 1917 to 1927 Biennial Survey of Education for cities with populations of 10,000 and over. ${ }^{*} \mathrm{p}<0.10,{ }^{* *} \mathrm{p}<0.05$, $* * * \mathrm{p}<0.01$. 


\section{$10 \quad$ Figures}

Figure 1: Timing of Suffrage Laws

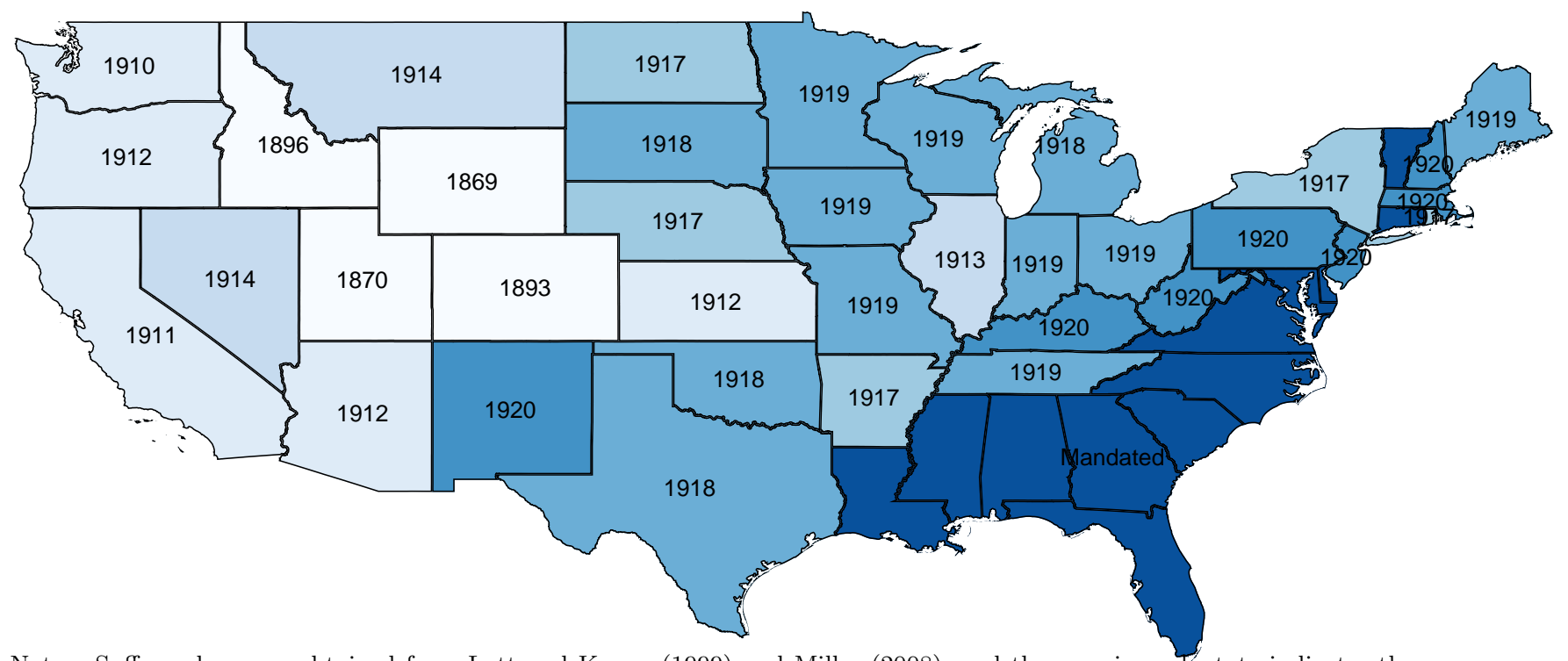

Notes: Suffrage laws are obtained from Lott and Kenny (1999) and Miller (2008), and the year in each state indicates the first suffrage law passed in the state. "Mandatory states" implemented suffrage as a result of the Nineteenth Amendment, in 1920. See text for further detail. 
Figure 2: Long-Run Effect of Suffrage on Years of Education

by Age of Exposure

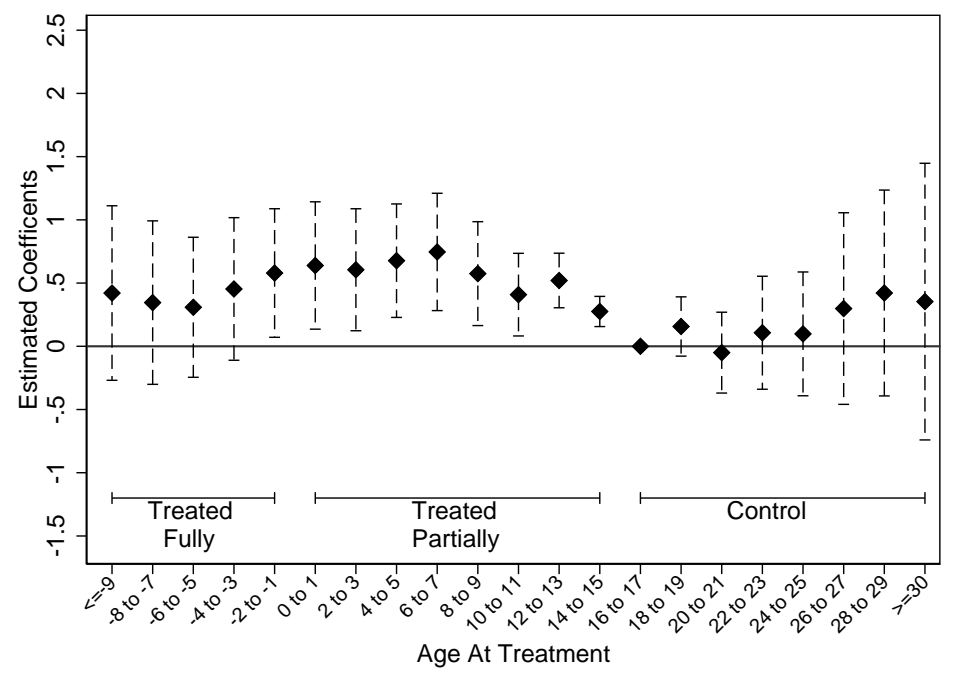

(a) Blacks

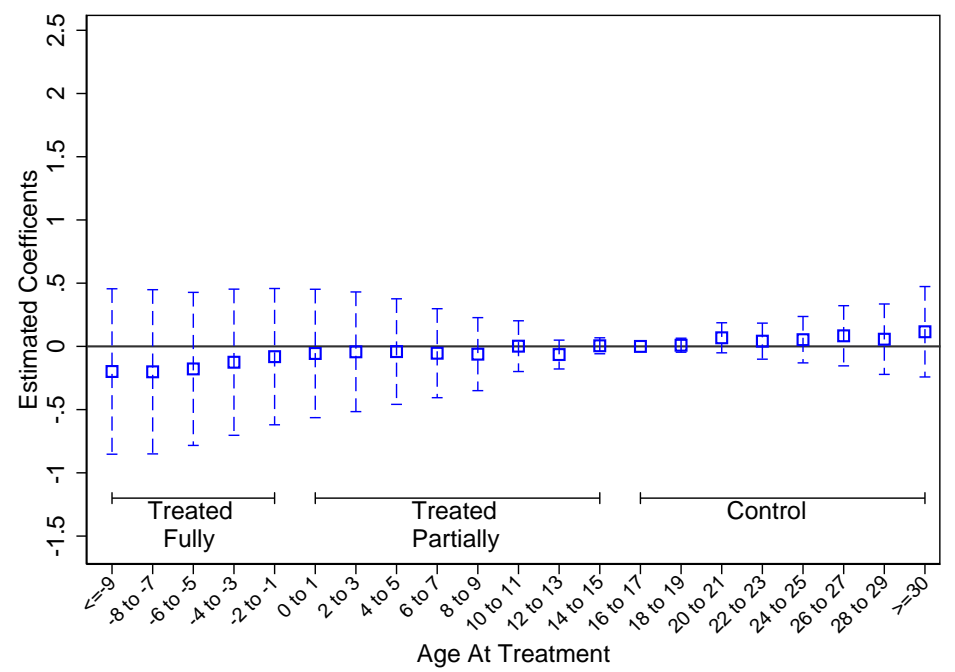

(b) Whites

Notes: This figure plots the estimated coefficients (and 95\% confidence intervals) obtained from event study specifications where the outcome is educational attainment, estimated separately for whites and blacks. All specifications include controls for demographics and state-level characteristics, birth state and birth year fixed effects, birth state linear time trends, as well as region-by-birth year and census year-by-birth year fixed effects. Age at treatment 16 to 17 is the omitted category so estimates are relative to that point. Estimates are weighted using Census sample weights, and standard errors are clustered on the state of birth. The sample consists of individuals born between 1880 and 1930, and that are at least 20 years old at the time of observation. We exclude states that passed suffrage prior to 1900. Source: 1940-1960 decennial censuses. 
Figure 3: Heterogeneous Effects of Exposure to Suffrage (Ages 0-15) on Education By Pre-Suffrage Average Education

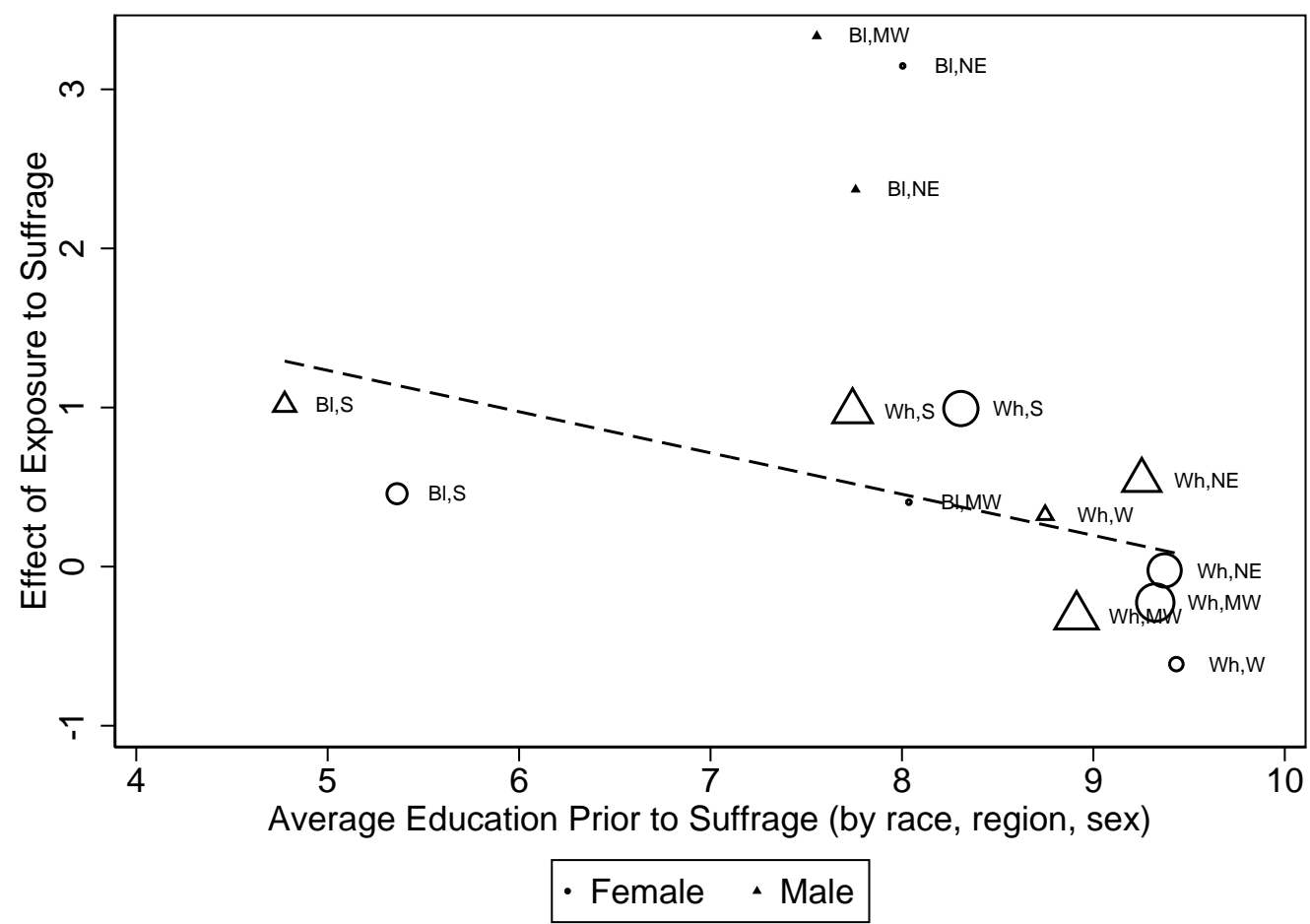

Notes: This figure shows coefficients (on the y-axis) from regressions of educational attainment on exposure to suffrage between ages $0-15$, estimated separately for groups defined according to region of birth, race and gender. The $\mathrm{x}$-axis shows the average pre-suffrage educational attainment (average attainment among individuals that were age 16 or older by the passage of suffrage in the state.) Marker size for each group is proportional to the number of observations in each group. Regions are abbreviated as follows: "S" for South, "W" for West, "MW" for Midwest, and "NE" for Northeast, and race is abbreviated as: "Bl" for black and "Wh" for white. We do not show blacks in the West due to their small sample size, but an equivalent figure that includes all groups is available on request. All regressions include controls for demographics and state-level characteristics, birth state and birth year fixed effects, birth state linear time trends, as well as region-by-birth year and census year-by-birth year fixed effects. Estimates are weighted using Census sample weights, and standard errors are clustered on the state of birth. The sample consists of individuals born between 1880 and 1930, and that are at least 20 years old at the time of observation. We exclude states that passed suffrage prior to 1900. Source: 1940-1960 decennial censuses. 
Figure 4: Distributional Effects of Exposure to Suffrage (Ages 0-15) on Education

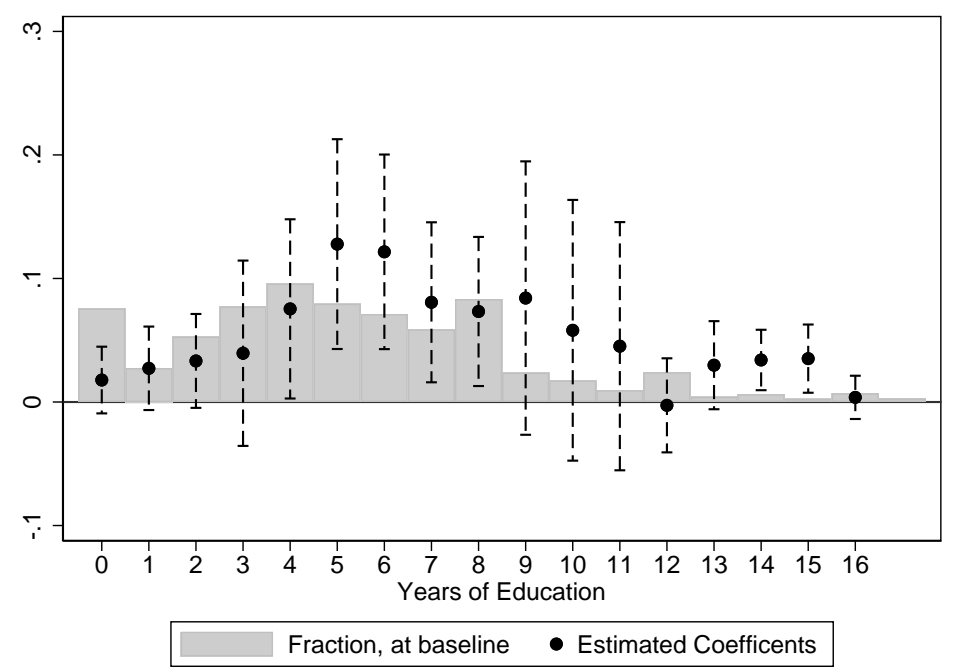

(a) Blacks

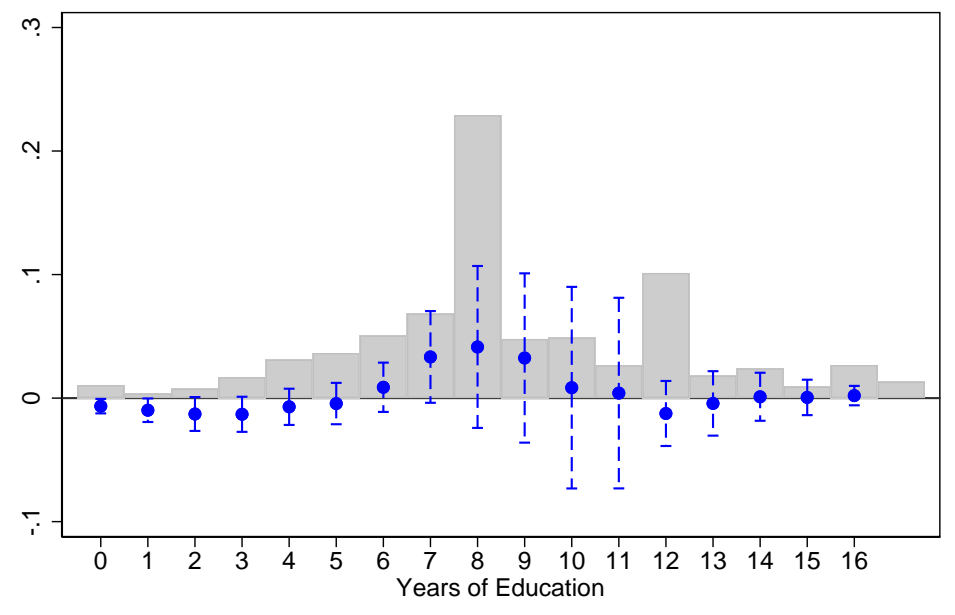

Fraction, at baseline $\bullet$ Estimated Coefficents

(b) Whites

Notes: These figures plot the estimated coefficients (and 95\% confidence intervals) from a series of regressions of indicators for whether an individual obtained $x$ or greater years of education (1-CDF), where $x$ is represented on the x-axis, on suffrage exposure between ages $0-15$. Regressions are estimated separately for white and blacks, and they include controls for demographics and state-level characteristics, birth state and birth year fixed effects, birth state linear time trends, as well as region-by-birth year and census year-by-birth year fixed effects. Estimates are weighted using Census sample weights, and standard errors are clustered on the state of birth. For reference, we also show a histogram of the completed education of individuals who were exposed to suffrage after age 15, who serve as the comparison group in these regressions. The sample consists of individuals born between 1880 and 1930, and that are at least 20 years old at the time of observation. We exclude states that passed suffrage prior to 1900. Source: 1940-1960 decennial censuses. 
Figure 5: Short-Run Effect of Suffrage on City-Level Log School Expenditures and Log Enrollment

(a) Heterogeneity by Pre-Suffrage Education Level in State

(i) Log Expenditures

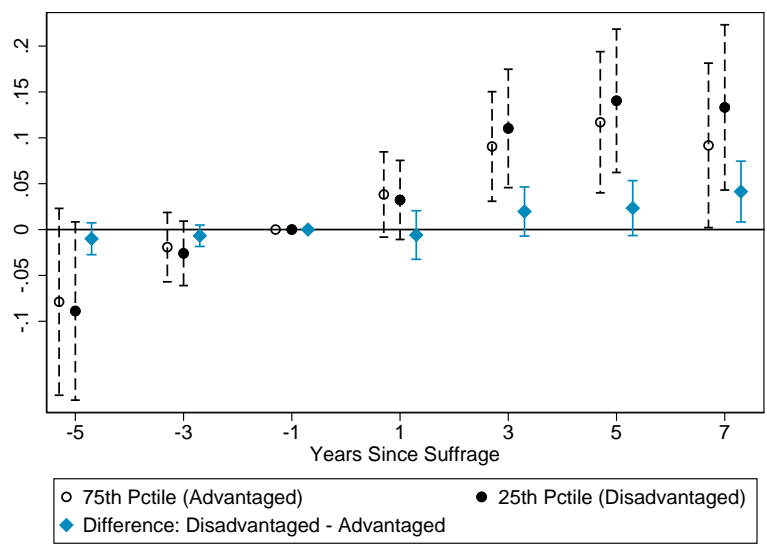

(ii) Log Enrollment

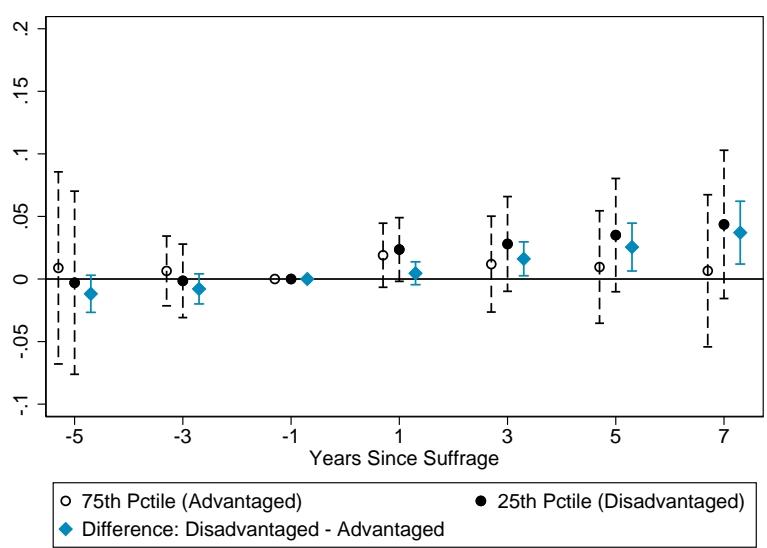

(b) Heterogeneity by 1910 Percent Black in City

(i) Log Expenditures

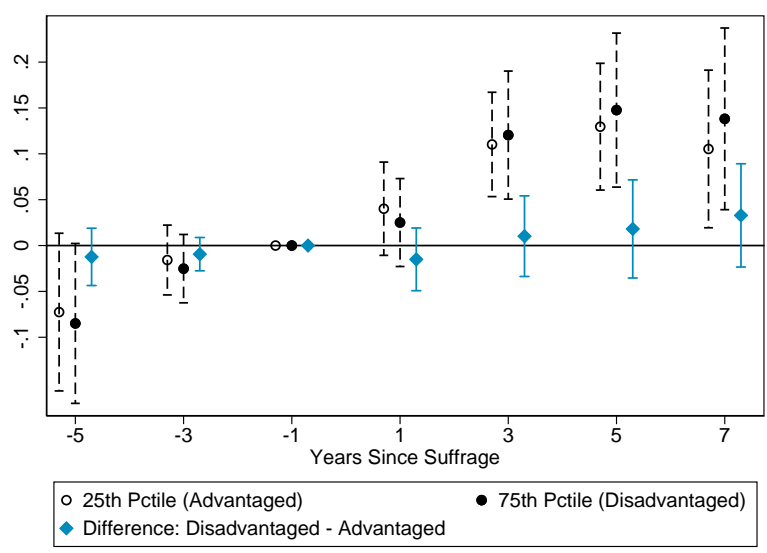

(ii) Log Enrollment

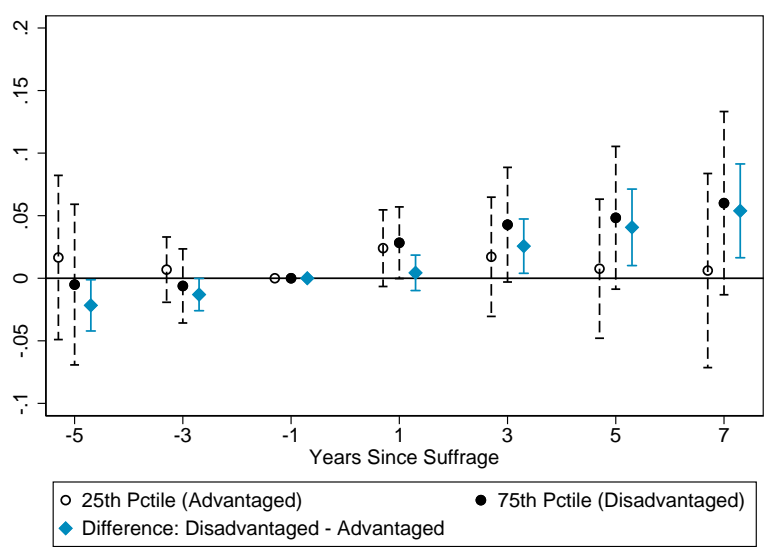

(c) Heterogeneity by South/Non-South

(i) Log Expenditures

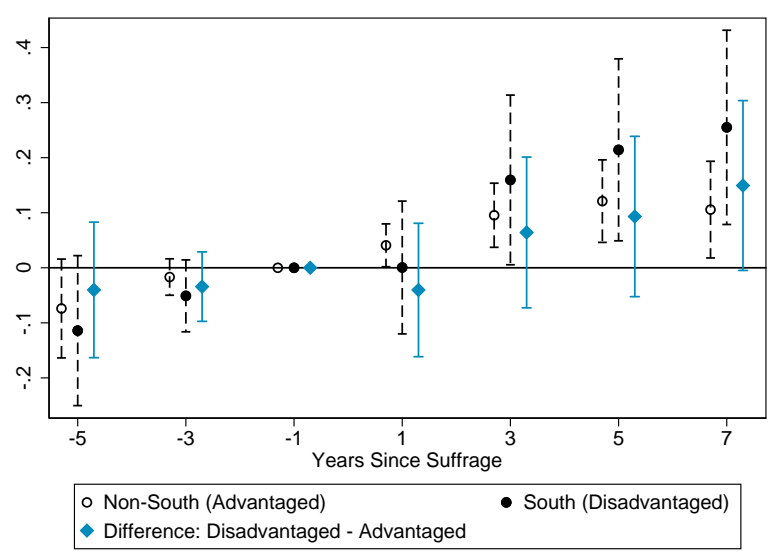

(ii) Log Enrollment

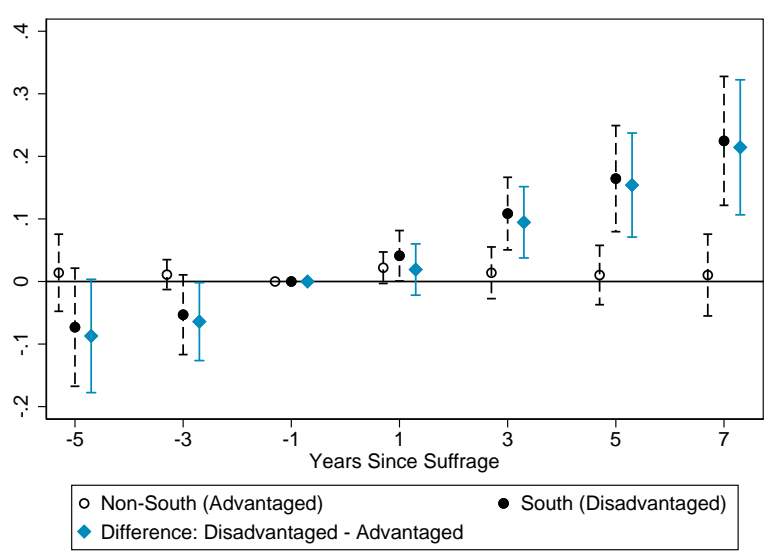

Notes: These figures are obtained from event study specifications that analyze the effect of suffrage on log expenditures and log enrollment, and that include an interaction between academic years since suffrage and one of our three measures of advantage. The figures shows the implied effects of suffrage for the $75^{t h}$ and $25^{t h}$ percentile of each of our continuous measures of status - education and share black - and for the South and non-South, as well as their difference. All regressions include controls for state-level characteristics, and city and academic year fixed effects. Estimates are weighted using city population in 1910, and standard errors are clustered on state. The sample consist 1 pf all cities with available expenditure, revenue and enrollment data, which we observe for at least 7 years, and which are not outliers. Source: 1909 to 1911 and 1913 to 1915 Report of the Commissioner of Education, and 1917 to 1927 Biennial Survey of Education for cities with populations of 10,000 and over. * $\mathrm{p}<0.10, * * \mathrm{p}<0.05, * * * \mathrm{p}<0.01$. 


\title{
ONLINE APPENDIX: \\ Women's Suffrage and Children's Education
}

\author{
Esra Kose, Elira Kuka and Na'ama Shenhav
}

June, 2020 


\section{A Appendix A: Empirical Appendix}

Table A.1: Progressive Voting in the Senate Before and After Suffrage

\begin{tabular}{|c|c|c|c|c|c|c|}
\hline & \multicolumn{2}{|c|}{ Share Yes on Prog. } & \multicolumn{2}{|c|}{ Share Abstain on Prog. } & \multicolumn{2}{|c|}{ Share No on Prog. } \\
\hline & Level & $\log$ & Level & $\log$ & Level & $\log$ \\
\hline \multicolumn{7}{|c|}{ A: Total Progressive Voting } \\
\hline Post Suffrage & $\begin{array}{l}-0.001 \\
(0.017)\end{array}$ & $\begin{array}{l}-0.002 \\
(0.047)\end{array}$ & $\begin{array}{c}-0.014 \\
(0.018)\end{array}$ & $\begin{array}{l}-0.050 \\
(0.071)\end{array}$ & $\begin{array}{l}0.015^{*} \\
(0.007)\end{array}$ & $\begin{array}{l}0.045^{* *} \\
(0.022)\end{array}$ \\
\hline Mean Y & 0.427 & -0.927 & 0.274 & -1.394 & 0.269 & -1.381 \\
\hline Observations & 13385 & 12987 & 13385 & 11313 & 13385 & 12535 \\
\hline \multicolumn{7}{|c|}{ B: Within-Politician Progressive Voting } \\
\hline Post Suffrage & $\begin{array}{c}-0.024^{*} \\
(0.014)\end{array}$ & $\begin{array}{c}-0.051 \\
(0.032) \\
\end{array}$ & $\begin{array}{c}0.020 \\
(0.017)\end{array}$ & $\begin{array}{c}0.020 \\
(0.072)\end{array}$ & $\begin{array}{c}0.003 \\
(0.008)\end{array}$ & $\begin{array}{c}0.013 \\
(0.024)\end{array}$ \\
\hline Mean Y & 0.433 & -0.904 & 0.260 & -1.470 & 0.279 & -1.341 \\
\hline Observations & 5642 & 5518 & 5642 & 4858 & 5642 & 5366 \\
\hline
\end{tabular}

Notes: This table contains results obtained when the dependent variable is (i) the share of progressive bills that a senator voted for (columns 1-2); (ii) the share of progressive bills that a senator abstained from (columns 34); and (iii) the share of progressive bills that the senator voted against (columns 5-6). We show results with levels in odd columns and logs in the even columns. Post-suffrage is an indicator for the years after suffrage was passed. Regressions include year fixed effects and state fixed effects. Standard errors are clustered at the state level. Panel A includes all senators voting between 1900 and 1930 (385 unique members), while Panel B only includes senators present for at least 1 year prior to suffrage, and 1 year after suffrage (108 unique members.) Sources: Coding of progressive and anti-progressive bills from Miller (2008), 1900-1930 Senate voting data from Voteview: Congressional Roll Call Votes Database. ${ }^{*} \mathrm{p}<0.10,{ }^{* *} \mathrm{p}<0.05,{ }^{* * *} \mathrm{p}<0.01$. 
Table A.2: Effect of Suffrage on Years of Education Change in Coefficients as Controls are Added

\begin{tabular}{lcccccc}
\hline \hline & $(1)$ & $(2)$ & $(3)$ & $(4)$ & $(5)$ & $(6)$ \\
\hline \hline A: All & & & & & & \\
Suff Share 0-15 & $0.462^{* *}$ & $0.442^{*}$ & $0.417^{* *}$ & $0.404^{* *}$ & $0.401^{* *}$ & 0.091 \\
& $(0.217)$ & $(0.231)$ & $(0.173)$ & $(0.179)$ & $(0.179)$ & $(0.203)$ \\
\hline Mean Education & 9.647 & 9.647 & 9.647 & 9.647 & 9.647 & 9.647 \\
Observations & 1555475 & 1555475 & 1555475 & 1555475 & 1555475 & 1555475 \\
& & & & & & \\
\hline B: Whites & & & & & & \\
Suff Share 0-15 & $0.417^{*}$ & 0.369 & $0.374^{* *}$ & $0.373^{* *}$ & $0.371^{* *}$ & 0.062 \\
& $(0.224)$ & $(0.236)$ & $(0.167)$ & $(0.169)$ & $(0.169)$ & $(0.197)$ \\
\hline Mean Education & 9.967 & 9.967 & 9.967 & 9.967 & 9.967 & 9.967 \\
Observations & 1393855 & 1393855 & 1393855 & 1393855 & 1393855 & 1393855 \\
& & & & & & \\
\hline C: Blacks & & & & & & \\
Suff Share 0-15 & $1.502^{* * *}$ & $1.470^{* * *}$ & $1.121^{* * *}$ & $1.111^{* * *}$ & $1.099^{* * *}$ & $0.884^{* * *}$ \\
& $(0.312)$ & $(0.279)$ & $(0.282)$ & $(0.283)$ & $(0.300)$ & $(0.295)$ \\
\hline Mean Education & 6.810 & 6.810 & 6.810 & 6.810 & 6.810 & 6.810 \\
Observations & 157028 & 157028 & 157028 & 157028 & 157028 & 157028 \\
BSt,BY FE & Yes & Yes & Yes & Yes & Yes & Yes \\
BSt Trends & & Yes & Yes & Yes & Yes & Yes \\
State Controls & & Yes & Yes & Yes & Yes \\
Compulsory and Rosenwald & & & Yes & Yes & Yes \\
CYxBY FE & & & & Yes & Yes \\
RegionxBY FE & & & & & Yes \\
\hline \hline
\end{tabular}

Notes: This table contains results obtained when the dependent variable is years of education and the main independent variable is suffrage exposure, which is defined as the share of time between birth and age 15 that an individual was exposed to a suffrage law in his state of birth. All regressions include controls for demographics and state-level characteristics, birth state and birth year fixed effects, birth state linear time trends, as well as region-by-birth year and census yearby-birth year fixed effects. Estimates are weighted using Census sample weights, and standard errors are clustered on the state of birth. The sample consists of individuals born between 1880 and 1930, and that are at least 20 years old at the time of observation. We exclude states that passed suffrage prior to 1900. Source: $1940-1960$ decennial censuses. ${ }^{*} \mathrm{p}<0.10,{ }^{* *} \mathrm{p}<0.05,{ }^{* * *}$ $\mathrm{p}<0.01$. 


\section{Table A.3: F-Tests Predicting Suffrage Year, Late Suffrage ( $\geq 1920)$, and Post-Suffrage: Levels of Covariates}

\begin{tabular}{|c|c|c|c|c|c|c|c|}
\hline & \multicolumn{2}{|c|}{1 to 3 yrs Pre-suff. (Suff. Yr >1917) } & \multicolumn{2}{|c|}{1900 (Suff. Yr >1910) } & \multicolumn{2}{|c|}{1910 (Suff. Yr >1910) } & \multirow{2}{*}{$\frac{3 \text { yrs. Pre-/Post- Suff }}{\text { Post }}$} \\
\hline & Suff. Yr. & Late & Suff. Yr. & Late & Suff. Yr. & Late & \\
\hline \multirow[t]{2}{*}{ Pct. White } & -0.015 & -0.013 & 6.854 & 0.149 & 0.405 & -0.179 & -0.062 \\
\hline & $(0.019)$ & $(0.012)$ & $(4.356)$ & $(0.917)$ & $(3.804)$ & $(0.760)$ & $(0.048)$ \\
\hline \multirow[t]{2}{*}{ Pct. Urban } & 0.003 & 0.004 & 0.019 & 0.006 & 0.016 & -0.000 & -0.020 \\
\hline & $(0.035)$ & $(0.022)$ & $(0.063)$ & $(0.013)$ & $(0.056)$ & $(0.011)$ & $(0.015)$ \\
\hline \multirow[t]{2}{*}{ Pct. Foreign } & -0.059 & -0.022 & & & & & 0.008 \\
\hline & $(0.039)$ & $(0.025)$ & & & & & $(0.033)$ \\
\hline \multirow[t]{2}{*}{ Ln Pop } & -0.715 & -0.404 & 1.120 & 0.129 & 0.529 & 0.139 & -0.616 \\
\hline & $(0.764)$ & $(0.483)$ & $(0.849)$ & $(0.179)$ & $(0.768)$ & $(0.153)$ & $(0.583)$ \\
\hline \multirow[t]{2}{*}{ Pct. Emp. Manuf. } & 5.472 & 3.030 & & & & & 0.448 \\
\hline & $(6.541)$ & $(4.133)$ & & & & & $(0.864)$ \\
\hline \multirow[t]{2}{*}{ Ln Manuf. Wage per Earner } & -1.409 & 0.350 & & & & & -1.378 \\
\hline & $(1.986)$ & $(1.255)$ & & & & & $(0.865)$ \\
\hline \multirow[t]{2}{*}{ Ln Avg. Farm Value } & 0.095 & 0.046 & & & & & 0.405 \\
\hline & $(0.599)$ & $(0.378)$ & & & & & $(0.307)$ \\
\hline \multirow[t]{2}{*}{ Ln Tax-Reported Income per Capita } & 0.245 & -0.010 & & & & & 0.077 \\
\hline & $(0.924)$ & $(0.584)$ & & & & & $(0.167)$ \\
\hline \multirow[t]{2}{*}{ Ln Number Hospitals } & 0.742 & 0.378 & & & & & -0.179 \\
\hline & $(0.866)$ & $(0.547)$ & & & & & $(0.140)$ \\
\hline \multirow[t]{2}{*}{ Ln Doctors per Capita } & -0.995 & -0.512 & & & & & 0.331 \\
\hline & $(1.018)$ & $(0.643)$ & & & & & $(0.770)$ \\
\hline \multirow[t]{2}{*}{ Ln Number of Schools per Capita } & -0.137 & -0.045 & & & & & \\
\hline & $(0.763)$ & $(0.482)$ & & & & & \\
\hline \multirow[t]{2}{*}{ Compulsory Attendance } & 0.030 & -0.030 & -0.134 & -0.025 & -0.036 & -0.039 & \\
\hline & $(0.132)$ & $(0.083)$ & $(0.184)$ & $(0.039)$ & $(0.307)$ & $(0.061)$ & \\
\hline \multirow[t]{2}{*}{ Schooling for Child Labor } & 0.011 & -0.052 & -0.269 & -0.026 & 0.330 & -0.082 & \\
\hline & $(0.151)$ & $(0.095)$ & $(0.160)$ & $(0.034)$ & $(0.442)$ & $(0.088)$ & \\
\hline \multirow[t]{2}{*}{ Pct. Foreign White } & & & -0.005 & -0.001 & $-0.011^{*}$ & -0.001 & \\
\hline & & & $(0.005)$ & $(0.001)$ & $(0.006)$ & $(0.001)$ & \\
\hline \multirow[t]{2}{*}{ Ln Total Value of Farms } & & & $-1.542^{*}$ & -0.164 & -1.040 & -0.234 & \\
\hline & & & $(0.804)$ & $(0.169)$ & $(0.748)$ & $(0.149)$ & \\
\hline Obs & 31 & 31 & 43 & 43 & 43 & 43 & 217 \\
\hline F-test P-Value & 0.401 & 0.659 & 0.263 & 0.607 & 0.441 & 0.422 & 0.266 \\
\hline Partial R2 & 0.317 & 0.188 & 0.109 & 0.080 & 0.087 & 0.102 & 0.006 \\
\hline
\end{tabular}

Notes: Columns 1-6 of this table test whether the year of suffrage (columns 1, 3, and 5) or or "late" suffrage (columns 2, 4, and 6), a dummy for suffrage year $\geq 1920$, is associated with levels of statelevel covariates prior to suffrage, net of region fixed effects. Columns 1-2 use annual covariates from Lleras-Muney (2002) from 1915-17, and restrict to states that passed suffrage after 1917, and columns 3-4 and 5-6, respectively use state-level covariates for 1900 and 1910 from ICPSR 2896, restricting to states that passed suffrage after 1910. Column 7 tests whether state-level demographic variables changed in the three years after suffrage, relative to the three years before suffrage, using the states from columns 1-2. We include regionxyear and state fixed effects for that specification. Standard errors are clustered on state in column (7). The F-test p-value comes from a test that the coefficients shown are jointly equal to zero, and the partial $R^{2}$ reports the $R^{2}$ of the variables shown in the table. ${ }^{*} \mathrm{p}<0.10,{ }^{* *} \mathrm{p}<0.05,{ }^{* * *} \mathrm{p}<0.01$. 
Table A.4: F-Tests Predicting Suffrage Year and Late Suffrage ( $\geq 1920)$ : Changes in Covariates

\begin{tabular}{|c|c|c|c|c|}
\hline & \multicolumn{2}{|c|}{ 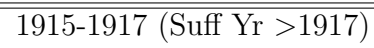 } & \multicolumn{2}{|c|}{ 1900-1910 (Suff Yr >1910) } \\
\hline & Suff. Yr. & Late & Suff. Yr. & Late \\
\hline \multirow[t]{2}{*}{ Chg. Pct. White } & 0.905 & 0.374 & -33.582 & -4.486 \\
\hline & $(0.575)$ & $(0.422)$ & $(21.067)$ & $(4.410)$ \\
\hline \multirow[t]{2}{*}{ Chg. Pct. Urban } & -0.352 & -0.092 & $0.643^{*}$ & $0.120^{*}$ \\
\hline & $(0.300)$ & $(0.220)$ & $(0.327)$ & $(0.068)$ \\
\hline \multirow[t]{2}{*}{ Chg. Pct. Foreign } & -0.630 & -0.532 & & \\
\hline & $(0.623)$ & $(0.457)$ & & \\
\hline \multirow[t]{2}{*}{ Chg. Pct. Emp. Manuf. } & -0.858 & -0.232 & & \\
\hline & $(4.350)$ & $(3.190)$ & & \\
\hline \multirow[t]{2}{*}{ Chg. Ln Pop } & -5.098 & -0.106 & -1.466 & -0.565 \\
\hline & $(8.388)$ & $(6.152)$ & $(2.037)$ & $(0.426)$ \\
\hline \multirow[t]{2}{*}{ Chg. Ln Manuf. Wage per Earner } & 5.133 & 3.963 & & \\
\hline & $(4.260)$ & $(3.124)$ & & \\
\hline \multirow[t]{2}{*}{ Chg. Ln Avg. Farm Value } & -11.349 & -2.712 & & \\
\hline & $(7.246)$ & $(5.314)$ & & \\
\hline \multirow[t]{2}{*}{ Chg. Ln Tax-Reported Income per Capita } & -0.563 & -0.214 & & \\
\hline & $(0.516)$ & $(0.378)$ & & \\
\hline \multirow[t]{2}{*}{ Chg. Ln Number Hospitals } & $-4.868^{*}$ & -2.487 & & \\
\hline & $(2.378)$ & $(1.744)$ & & \\
\hline \multirow[t]{2}{*}{ Chg. Ln Doctors per Capita } & 5.920 & -0.401 & & \\
\hline & $(9.567)$ & $(7.016)$ & & \\
\hline \multirow[t]{2}{*}{ Chg. Ln Number of Schools per Capita } & -0.861 & -0.667 & & \\
\hline & $(1.861)$ & $(1.365)$ & & \\
\hline \multirow[t]{2}{*}{ Chg. Compulsory Attendance } & -0.099 & -0.036 & 0.180 & 0.031 \\
\hline & $(0.139)$ & $(0.102)$ & $(0.148)$ & $(0.031)$ \\
\hline \multirow[t]{2}{*}{ Chg. Schooling for Child Labor } & 0.182 & 0.057 & 0.212 & 0.010 \\
\hline & $(0.149)$ & $(0.109)$ & $(0.151)$ & $(0.032)$ \\
\hline \multirow[t]{2}{*}{ Chg. Pct. Foreign White } & & & -0.021 & -0.001 \\
\hline & & & $(0.019)$ & $(0.004)$ \\
\hline \multirow[t]{2}{*}{ Chg. Ln Total Value of Farms } & & & -1.612 & -0.218 \\
\hline & & & $(1.457)$ & $(0.305)$ \\
\hline Obs & 31 & 31 & 43 & 43 \\
\hline F-test P-Value & 0.071 & 0.410 & 0.139 & 0.333 \\
\hline Partial R2 & 0.304 & 0.047 & 0.131 & 0.114 \\
\hline
\end{tabular}

Notes: This table tests whether the year of suffrage (columns 1 and 3) or "late" suffrage (columns 2 and 4), a dummy for suffrage year $\geq 1920$, is associated with changes in state-level covariates prior to suffrage, net of region fixed effects. Columns 1-2 use annual data from Lleras-Muney (2002) from 1915-17, limiting the sample to states that passed suffrage after 1917, and columns 3-4 use state-level covariates for 1900 and 1910 from ICPSR 2896, limiting the sample to states that passed suffrage after 1910. Hence, the independent variables are either changes in state-level covariates between 1915-17 (columns 1 and 2) or changes in statelevel covariates between 1900-10. There were no changes in compulsory schooling laws between 1915-17 for this sample, so instead we use changes from 1907-17 in columns (1)-(2). The F-test p-value comes from a test that the coefficients shown are jointly equal to zero, and the partial $R^{2}$ reports the $R^{2}$ of the variables shown in the table. ${ }^{*} \mathrm{p}<0.10,{ }^{* *} \mathrm{p}<0.05,{ }^{* * *} \mathrm{p}<0.01$. 


\section{Table A.5: Correlation between Timing of Suffrage and Progressive Era Laws}

Year of Workers' Compensation Law -0.145

Year of Prohibition

$(0.082)$

Year of Women's Minimum Wage Law

Year of State Mother's Pension Law

Year of State General Federation of Women's Clubs Chapter

0.696

$(0.417)$

Year of Women's Maximum Hour Law

$-0.270$

$(0.391)$

\begin{tabular}{llllllll}
\hline Observations & 47 & 29 & 15 & 46 & 48 & 40 \\
\hline
\end{tabular}

Notes: This table contains results obtained when the dependent variable is the year of suffrage approved in each state and the main independent variable is the year of the listed Progressive era law. All regressions include region fixed effects. Sources: Suffrage laws are from Lott and Kenny (1999) and Miller (2008). Data on mother's pension laws, state General Federation of Women's Clubs chapter establishment, women's maximum hour laws, women's minimum wage laws from Skocpol (1992); workers' compensation law dates from Kantor and Fishback (1996); and state prohibition laws from Depew, Edwards and Owens (2013).

Table A.6: Correlation between Timing of Suffrage and New Deal Spending

\begin{tabular}{lccc}
\hline \hline & \multicolumn{3}{c}{ Outcome = Year Suffrage } \\
\cline { 2 - 4 } & $(1)$ & $(2)$ & $(3)$ \\
\hline Total Relief per Capita (1967 dol.) & 0.018 & \\
& $(0.027)$ & \\
Direct Relief per Capita (1967 dol.) & \multicolumn{3}{c}{0.015} \\
& & $(0.039)$ & \\
Work Relief per Capita (1967 dol.) & & \multicolumn{3}{c}{0.031} \\
& \multicolumn{3}{c}{$(0.070)$} \\
\hline Observations & 36 & 36 & 36 \\
X mean & 133 & 74 & 32 \\
\hline \hline
\end{tabular}

Notes: This table contains results obtained when the dependent variable is the year that suffrage was approved in each state and the main independent variable is the generosity of New Deal relief spending in the state, the total $(1967 \$)$ spent between 1929 and 1940 normalized by the 1930 population (Fishback, Haines and Kantor, 2007). All regressions include region fixed effects. Total relief is the sum of direct and work relief, and is sourced from data made available from Fishback, Haines and Kantor (2007). The sample excludes states that passed suffrage prior to 1900. Suffrage laws are from Lott and Kenny (1999) and Miller (2008). ${ }^{*} \mathrm{p}<0.10,{ }^{* *} \mathrm{p}<0.05,{ }^{* * *} \mathrm{p}<0.01$. 
Table A.7: Correlation between Suffrage and Compulsory Schooling Laws

\begin{tabular}{lcc}
\hline \hline & Comp. Attendance & Child Labor \\
\hline Post Suffrage Law & -0.545 & 0.352 \\
& $(0.437)$ & $(0.420)$ \\
\hline Observations & 1488 & 1488 \\
\hline \hline
\end{tabular}

Notes: This table contains results obtained when the dependent variable is the parameter of a compulsory schooling or child labor law and the main independent variable is an indicator for whether suffrage was passed in the state. All regressions include state fixed effects, state trends, and region by year fixed effects. Standard errors are clustered at the state level. Sources: Data used in Goldin and Katz (2003) obtained from the website of Claudia Goldin. ${ }^{*} \mathrm{p}<0.10,{ }^{* *}$ $\mathrm{p}<0.05,{ }^{* * *} \mathrm{p}<0.01$.

Table A.8: Correlation between Suffrage and the Elements of Compulsory Schooling Laws

\begin{tabular}{lcccc}
\hline \hline & Age Leave Sch. & Age Work & Min Sch. to Work & Min Sch. to Drop \\
\hline Post Suffrage Law & -0.110 & 0.284 & -0.397 & -0.510 \\
& $(0.365)$ & $(0.985)$ & $(0.476)$ & $(2.958)$ \\
\hline Observations & 1466 & 1488 & 1392 & 1422 \\
\hline \hline
\end{tabular}

Notes: This table contains results obtained when the dependent variable is the parameter of a compulsory schooling or child labor law and the main independent variable is an indicator for whether suffrage was passed in the state. All regressions include state fixed effects, state trends, and region by year fixed effects. Standard errors are clustered at the state level. Sources: Data used in Goldin and Katz (2003) obtained from the website of Claudia Goldin. ${ }^{*} \mathrm{p}<0.10$, ** $\mathrm{p}<0.05, * * * \mathrm{p}<0.01$. 
Table A.9: Effect of Suffrage on Years of Education Marginal Effect of Each Additional Year of Exposure by Age

\begin{tabular}{lccc}
\hline \hline & & & \\
\cline { 2 - 4 } & All & Whites & Blacks \\
\hline Add'l Effect of Treatment from 0-5 & 0.007 & 0.008 & -0.000 \\
& $(0.009)$ & $(0.008)$ & $(0.027)$ \\
Add'l Effect of Treatment between 6-10 & 0.005 & 0.000 & $0.090^{* *}$ \\
& $(0.019)$ & $(0.018)$ & $(0.035)$ \\
Effect of Treatment between 11-15 & 0.005 & 0.004 & $0.079^{* * *}$ \\
& $(0.013)$ & $(0.013)$ & $(0.028)$ \\
\hline Mean Education & 9.647 & 9.967 & 6.810 \\
P-Value for Test of Equality & 0.979 & 0.854 & 0.095 \\
R-Squared & 0.194 & 0.123 & 0.215 \\
Observations & 1555475 & 1393855 & 157028 \\
\hline \hline
\end{tabular}

Notes: This table contains results obtained when the dependent variable is years of education and the main independent variables are a spline in the number of years an individual is treated between the ages of 0 and 15 . Therefore the coefficient for "Treated between X-Y" is the additional impact of one year of treatment during that age range; the text described an example for calculating the total effect of exposure to suffrage. All regressions include controls for demographics and state-level characteristics, birth state and birth year fixed effects, birth state linear time trends, as well as region-by-birth year and census year-by-birth year fixed effects. All regressions include sample weights, and standard errors are clustered at the state level. The sample consists of individuals born between 1880 and 1930, and that are at least 20 years old at the time of observation. We exclude states that passed suffrage prior to 1900. Source: 1940-1960 decennial censuses. Source: $1940-1960$ decennial censuses. ${ }^{*} \mathrm{p}<0.10,{ }^{* *} \mathrm{p}<0.05,{ }^{* * *} \mathrm{p}<0.01$. 
Table A.10: Effect of Suffrage on Years of Education Effects Beyond Age 15

\begin{tabular}{lccc}
\hline \hline & All & Whites & Blacks \\
\hline Suff Share 0-15 & 0.090 & 0.054 & $0.738^{* * *}$ \\
& $(0.242)$ & $(0.236)$ & $(0.230)$ \\
Suff Share 16-22 & 0.008 & -0.011 & -0.033 \\
& $(0.071)$ & $(0.071)$ & $(0.263)$ \\
Suff Share 23-30 & -0.012 & -0.008 & -0.417 \\
& $(0.104)$ & $(0.105)$ & $(0.404)$ \\
\hline Mean Education & 9.647 & 9.967 & 6.810 \\
R-Squared & 0.194 & 0.123 & 0.215 \\
Observations & 1555475 & 1393855 & 157028 \\
\hline \hline
\end{tabular}

Notes: This table contains results obtained when the dependent variable is years of education and the main independent variables are "Suff Share $\mathrm{x}-\mathrm{y}$ ", which are defined as the share of time between ages $\mathrm{x}$ and $\mathrm{y}$ that an individual was exposed to a suffrage law in his state of birth. All regressions include controls for demographics and state-level characteristics, birth state and birth year fixed effects, birth state linear time trends, as well as region-by-birth year and census yearby-birth year fixed effects. All regressions include sample weights, and standard errors are clustered at the state level. The sample consists of individuals born between 1880 and 1930, and that are at least 20 years old at the time of observation. We exclude states that passed suffrage prior to 1900. Source: 1940-1960 decennial censuses. ${ }^{*} \mathrm{p}<0.10,{ }^{* *} \mathrm{p}<0.05,{ }^{* * *} \mathrm{p}<0.01$. 


\section{Table A.11: Effect of Suffrage on Years of Education - Differential Effects by Region}

\begin{tabular}{lccc}
\hline \hline & All & White & Black \\
\hline Suff Share 0-15 x Northeast & $0.291^{*}$ & 0.267 & $1.161^{*}$ \\
& $(0.168)$ & $(0.168)$ & $(0.686)$ \\
& & & \\
Suff Share 0-15 x Midwest & -0.168 & -0.169 & $0.989^{* * *}$ \\
& $(0.258)$ & $(0.253)$ & $(0.324)$ \\
& & & \\
Suff Share 0-15 x South & $1.018^{* *}$ & $0.957^{* *}$ & 0.696 \\
& $(0.470)$ & $(0.473)$ & $(0.432)$ \\
& & & \\
Suff Share 0-15 x West & $0.540^{* * *}$ & $0.544^{* *}$ & $13.683^{* * *}$ \\
& $(0.193)$ & $(0.213)$ & $(4.161)$ \\
\hline Mean Education & 9.647 & 9.967 & 6.810 \\
P-Value NE=MW=S=W & 0.057 & 0.065 & 0.029 \\
P-Value NE=MW=S & 0.074 & 0.096 & 0.794 \\
Observations & 1555475 & 1393855 & 157028 \\
\hline \hline
\end{tabular}

Notes: This table contains results obtained when the dependent variable is years of education and the main independent variable is suffrage exposure, which is defined as the share of time between birth and age 15 that an individual was exposed to a suffrage law in his state of birth. All regressions include controls for demographics and state-level characteristics, birth state and birth year fixed effects, birth state linear time trends, as well as census yearby-birth year fixed effects. Estimates are weighted using Census sample weights, and standard errors are clustered on the state of birth. The sample consists of individuals born between 1880 and 1930 , and that are at least 20 years old at the time of observation. We exclude states that passed suffrage prior to 1900 . The bottom rows of the table test the hypothesis that the effects are equal for all four regions (NE, MW, S, W) or for all regions except the West, since there we have some concerns about overfitting for blacks in the West. For reference, the number of observations for whites (blacks) in the NE, MW, S, and $\mathrm{W}$, respectively, is: 397,080 (7,381); 509,551 (7,946); 421,211 (140,982); 66,013 (537). The average years of education for whites (blacks) pre-suffrage in the NE, MW, S, and W, respectively, is: 9.3 (7.9); 9.1 (7.8); 8.0 (5.1); 9.1 (7.9). Source: 1940-1960 decennial censuses. ${ }^{*} \mathrm{p}<0.10$, $* * \mathrm{p}<0.05, * * * \mathrm{p}<0.01$ 
Table A.12: Effect of Suffrage on Log Infant Mortality Interactions with South and with Pre-Suffrage Education Levels

\begin{tabular}{|c|c|c|c|}
\hline & 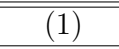 & $(2)$ & (3) \\
\hline \multicolumn{4}{|l|}{ A: All } \\
\hline Post Suffrage & $\begin{array}{c}-0.081^{* *} \\
(0.031)\end{array}$ & $\begin{array}{c}-0.059^{* *} \\
(0.025)\end{array}$ & $\begin{array}{c}-0.629^{* *} \\
(0.272)\end{array}$ \\
\hline Post Suffrage x South & & $\begin{array}{c}-0.125^{* *} \\
(0.057)\end{array}$ & \\
\hline Post Suffrage $*$ Pre-Period Average Education & & & $\begin{array}{c}0.061^{* *} \\
(0.028)\end{array}$ \\
\hline Mean Y & 8.820 & 8.820 & 8.820 \\
\hline Observations & 760 & 760 & 760 \\
\hline N States & 43 & 43 & 43 \\
\hline \multicolumn{4}{|l|}{ B: Whites } \\
\hline Post Suffrage & $\begin{array}{c}-0.096^{* *} \\
(0.037)\end{array}$ & $\begin{array}{c}-0.078^{* *} \\
(0.032)\end{array}$ & $\begin{array}{c}-0.760^{*} \\
(0.380)\end{array}$ \\
\hline Post Suffrage x South & & $\begin{array}{l}-0.100 \\
(0.061)\end{array}$ & \\
\hline Post Suffrage $*$ Pre-Period Average Education & & & $\begin{array}{c}0.073^{*} \\
(0.040)\end{array}$ \\
\hline Mean Y & 8.667 & 8.667 & 8.667 \\
\hline Observations & 724 & 724 & 724 \\
\hline N States & 43 & 43 & 43 \\
\hline \multicolumn{4}{|l|}{ C: Blacks } \\
\hline$\overline{\text { Post Suffrage }}$ & $\begin{array}{l}-0.015 \\
(0.047)\end{array}$ & $\begin{array}{c}0.061 \\
(0.051)\end{array}$ & $\begin{array}{c}-0.772^{* * *} \\
(0.221)\end{array}$ \\
\hline Post Suffrage x South & & $\begin{array}{c}-0.424^{* * *} \\
(0.108)\end{array}$ & \\
\hline Post Suffrage * Pre-Period Average Education & & & $\begin{array}{c}0.101^{* * *} \\
(0.030)\end{array}$ \\
\hline Mean Y & 5.703 & 5.703 & 5.703 \\
\hline Observations & 677 & 677 & 675 \\
\hline N States & 42 & 42 & 41 \\
\hline
\end{tabular}

Notes: The dependent variable is log infant mortality. Post suffrage is a dummy variable that takes the value of one if the state passed suffrage by the current year. We include interactions between post suffrage and either South (column 2) or presuffrage education levels (column 3). Pre-suffrage education is calculated for each state (and race for Panels $\mathrm{B}$ and $\mathrm{C}$ ) as the average education in that sample among individuals age 16 and above in the year that suffrage was passed. All regressions include controls for state-level characteristics, state and year fixed effects, and state linear time trends. Estimates are weighted using population weights, and standard errors are clustered on the state. We exclude states that passed suffrage prior to 1900. Source: 1900 to 1932 mortality records by state, age, race, and gender from the Centers for Disease Control and Prevention. ${ }^{*} \mathrm{p}<0.10,{ }^{* *} \mathrm{p}<0.05,{ }^{* * *} \mathrm{p}<0.01$. 
Table A.13: Effect of Suffrage on Years of Education Accounting for Selective Survivorship with Lee (2009) Bounds

\begin{tabular}{lccccc}
\hline \hline & \multicolumn{2}{l}{ Bounds for Whites } & & \multicolumn{2}{c}{ Bounds for Blacks } \\
\cline { 2 - 3 } \cline { 5 - 6 } & Lower & Upper & & Lower & Upper \\
\hline Suff Share 0-15 & -0.143 & $0.645^{* *}$ & & 0.914 & $3.151^{* * *}$ \\
& $(0.200)$ & $(0.280)$ & & $(0.552)$ & $(0.626)$ \\
\hline Observations & 1348682 & 1350468 & & 139785 & 142347 \\
\hline \hline
\end{tabular}

Notes: This table presents estimates when we trim the sample following Lee (2009) to account for selection from the decline in infant mortality following suffrage. In columns (1) and (3) we drop the top $\mathrm{X} \%$ of completed education outcomes among the sample exposed to suffrage by age 1 , where $\mathrm{X}$ is the percent change in mortality by South/non-South and race that we estimate in Appendix Table A.12. In columns (2) and (4) we drop the bottom X\% of completed education outcomes among the sample exposed to suffrage by age 1 . Estimates are weighted using Census sample weights, and standard errors are clustered on the state of birth. The sample consists of individuals born between 1880 and 1930, and that are at least 20 years old at the time of observation. We exclude states that passed suffrage prior to 1900. Source: 1940-1960 decennial censuses. $\mathrm{p}<0.10$, ** $\mathrm{p}<0.05, * * * \mathrm{p}<0.01$. 
Table A.14: Frequency of Growth in Local Real Schooling Revenues

\begin{tabular}{|c|c|c|c|}
\hline & All & South & Non-South \\
\hline Average number of year to year changes per city & $\begin{array}{c}9.67 \\
(1.45)\end{array}$ & $\begin{array}{c}9.16 \\
(1.59)\end{array}$ & $\begin{array}{c}9.77 \\
(1.40)\end{array}$ \\
\hline \multicolumn{4}{|l|}{ A: Revenues } \\
\hline 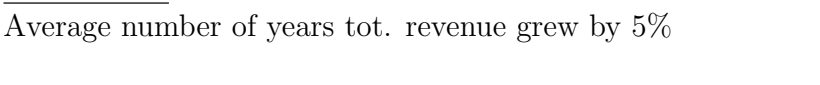 & $\begin{array}{c}3.57 \\
(1.19)\end{array}$ & $\begin{array}{c}3.29 \\
(1.13)\end{array}$ & $\begin{array}{c}3.63 \\
(1.20)\end{array}$ \\
\hline Average number of years tot. revenue grew by $10 \%$ & $\begin{array}{c}3.33 \\
(1.20)\end{array}$ & $\begin{array}{c}3.09 \\
(1.12)\end{array}$ & $\begin{array}{c}3.38 \\
(1.21)\end{array}$ \\
\hline Average number of years tot. revenue grew by $25 \%$ & $\begin{array}{c}2.62 \\
(1.12)\end{array}$ & $\begin{array}{c}2.50 \\
(1.13)\end{array}$ & $\begin{array}{c}2.64 \\
(1.12)\end{array}$ \\
\hline Share of years tot. revenue grew by $5 \%$ & $\begin{array}{c}0.37 \\
(0.11)\end{array}$ & $\begin{array}{c}0.36 \\
(0.11)\end{array}$ & $\begin{array}{c}0.37 \\
(0.11)\end{array}$ \\
\hline Share of years tot. revenue grew by $10 \%$ & $\begin{array}{c}0.34 \\
(0.11)\end{array}$ & $\begin{array}{c}0.34 \\
(0.11)\end{array}$ & $\begin{array}{c}0.34 \\
(0.11)\end{array}$ \\
\hline Share of years tot. revenue grew by $25 \%$ & $\begin{array}{c}0.27 \\
(0.11) \\
\end{array}$ & $\begin{array}{c}0.27 \\
(0.11)\end{array}$ & $\begin{array}{c}0.27 \\
(0.10)\end{array}$ \\
\hline Observations & 482 & 80 & 402 \\
\hline \multicolumn{4}{|l|}{ B: Revenues Per Pupil } \\
\hline 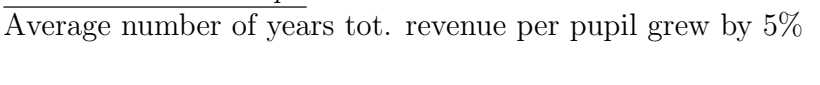 & $\begin{array}{l}3.647 \\
(1.19)\end{array}$ & $\begin{array}{l}3.325 \\
(1.20)\end{array}$ & $\begin{array}{l}3.711 \\
(1.17)\end{array}$ \\
\hline Average number of years tot. revenue per pupil grew by $10 \%$ & $\begin{array}{c}3.402 \\
(1.17)\end{array}$ & $\begin{array}{l}3.013 \\
(1.15)\end{array}$ & $\begin{array}{l}3.480 \\
(1.16)\end{array}$ \\
\hline Average number of years tot. revenue per pupil grew by $25 \%$ & $\begin{array}{l}2.668 \\
(1.09)\end{array}$ & $\begin{array}{l}2.425 \\
(1.17)\end{array}$ & $\begin{array}{l}2.716 \\
(1.07)\end{array}$ \\
\hline Share of years tot. revenue per pupil grew by $5 \%$ & $\begin{array}{l}0.375 \\
(0.10)\end{array}$ & $\begin{array}{l}0.362 \\
(0.11)\end{array}$ & $\begin{array}{l}0.378 \\
(0.10)\end{array}$ \\
\hline Share of years tot. revenue per pupil grew by $10 \%$ & $\begin{array}{l}0.350 \\
(0.11)\end{array}$ & $\begin{array}{l}0.328 \\
(0.11)\end{array}$ & $\begin{array}{l}0.355 \\
(0.10)\end{array}$ \\
\hline Share of years tot. revenue per pupil grew by $25 \%$ & $\begin{array}{l}0.275 \\
(0.10) \\
\end{array}$ & $\begin{array}{l}0.264 \\
(0.11) \\
\end{array}$ & $\begin{array}{l}0.277 \\
(0.10) \\
\end{array}$ \\
\hline Observations & 482 & 80 & 402 \\
\hline
\end{tabular}

Notes: This table reports the average number of years that cities experience at least an $\mathrm{x} \%$ growth in real revenue and real revenue per pupil over two consecutive years, where $\mathrm{x}$ takes values of 5 , 15 and $25 \%$. The sample consists of all cities with available expenditure, revenue and enrollment data, which we observe for at least 7 years, and which are not outliers. See sample restrictions in the notes of Table 5. Source: 1909 to 1911 and 1913 to 1915 Report of the Commissioner of Education, and 1917 to 1927 Biennial Survey of Education for cities with populations of 10,000 and over. 
Table A.15: Effect of Suffrage on Log Expenditures and Enrollment Heterogeneity by Pre-Suffrage Education, Share Black, and South

\begin{tabular}{|c|c|c|c|c|c|c|}
\hline & \multicolumn{3}{|c|}{ Expenditures } & \multicolumn{3}{|c|}{ Enrollment } \\
\hline & Pre-Ed & 1910 Black & South & Pre-Ed & 1910 Black & South \\
\hline \multicolumn{7}{|l|}{ Years Relative to Suffrage } \\
\hline \multirow[t]{2}{*}{$5+$ Years Prior } & -0.261 & -0.071 & -0.074 & -0.206 & 0.019 & 0.014 \\
\hline & $(0.159)$ & $(0.046)$ & $(0.048)$ & $(0.137)$ & $(0.035)$ & $(0.033)$ \\
\hline \multirow[t]{2}{*}{ 3-4 Years Prior } & -0.142 & -0.015 & -0.017 & -0.137 & 0.008 & 0.011 \\
\hline & $(0.108)$ & $(0.021)$ & $(0.018)$ & $(0.117)$ & $(0.014)$ & $(0.013)$ \\
\hline \multirow[t]{2}{*}{ 0-1 Years After } & -0.070 & 0.042 & $0.041^{*}$ & 0.102 & 0.024 & 0.022 \\
\hline & $(0.250)$ & $(0.028)$ & $(0.021)$ & $(0.088)$ & $(0.017)$ & $(0.014)$ \\
\hline \multirow[t]{2}{*}{ 2-3 Years After } & $0.448^{*}$ & $0.109^{* * *}$ & $0.095^{* * *}$ & $0.305^{* *}$ & 0.015 & 0.014 \\
\hline & $(0.263)$ & $(0.031)$ & $(0.031)$ & $(0.130)$ & $(0.026)$ & $(0.022)$ \\
\hline \multirow[t]{2}{*}{ 4-5 Years After } & $0.542^{*}$ & $0.128^{* * *}$ & $0.121^{* * *}$ & $0.473^{* *}$ & 0.004 & 0.010 \\
\hline & $(0.289)$ & $(0.037)$ & $(0.040)$ & $(0.184)$ & $(0.030)$ & $(0.026)$ \\
\hline \multirow{2}{*}{$6+$ Years After } & $0.844^{* *}$ & $0.102^{* *}$ & $0.106^{* *}$ & $0.680^{* * *}$ & 0.001 & 0.010 \\
\hline & $(0.319)$ & $(0.046)$ & $(0.047)$ & $(0.239)$ & $(0.042)$ & $(0.035)$ \\
\hline \multirow[t]{2}{*}{ eventyr1_x } & 0.019 & -0.145 & -0.040 & 0.023 & $-0.254^{*}$ & $-0.087^{*}$ \\
\hline & $(0.018)$ & $(0.196)$ & $(0.066)$ & $(0.016)$ & $(0.129)$ & $(0.049)$ \\
\hline \multirow[t]{2}{*}{ eventyr $2 \_x$} & 0.013 & -0.110 & -0.034 & 0.015 & $-0.153^{*}$ & $-0.064^{*}$ \\
\hline & $(0.012)$ & $(0.114)$ & $(0.034)$ & $(0.013)$ & $(0.081)$ & $(0.034)$ \\
\hline \multirow[t]{2}{*}{ eventyr4_x } & 0.012 & -0.176 & -0.040 & -0.009 & 0.051 & 0.019 \\
\hline & $(0.028)$ & $(0.215)$ & $(0.065)$ & $(0.010)$ & $(0.089)$ & $(0.022)$ \\
\hline \multirow[t]{2}{*}{ eventyr5_x } & -0.038 & 0.120 & 0.064 & $-0.031^{* *}$ & $0.300^{* *}$ & $0.095^{* * *}$ \\
\hline & $(0.028)$ & $(0.276)$ & $(0.074)$ & $(0.014)$ & $(0.136)$ & $(0.031)$ \\
\hline \multirow[t]{2}{*}{ eventyr6_x } & -0.045 & 0.212 & 0.093 & $-0.050^{* *}$ & $0.476^{* *}$ & $0.154^{* * *}$ \\
\hline & $(0.031)$ & $(0.336)$ & $(0.078)$ & $(0.020)$ & $(0.192)$ & $(0.045)$ \\
\hline \multirow[t]{2}{*}{ eventyr7_x } & $-0.080^{* *}$ & 0.385 & $0.149^{*}$ & $-0.072^{* * *}$ & $0.631^{* *}$ & $0.214^{* * *}$ \\
\hline & $(0.035)$ & $(0.354)$ & $(0.083)$ & $(0.026)$ & $(0.235)$ & $(0.058)$ \\
\hline Obs & 5183 & 2453 & 5183 & 5183 & 2453 & 5183 \\
\hline Pre-X Mean & 8.93 & 0.08 & 0.19 & 8.93 & 0.08 & 0.19 \\
\hline Pre-X 25th Pct & 8.83 & 0.01 & & 8.83 & 0.01 & \\
\hline Pre-X 75th Pct & 9.35 & 0.09 & & 9.35 & 0.09 & \\
\hline N Cities & 523 & 233 & 523 & 523 & 233 & 523 \\
\hline N States & 42 & 37 & 42 & 42 & 37 & 42 \\
\hline
\end{tabular}

Notes: This table contains results obtained when the dependent variables are log expenditures and $\log$ enrollment, and the independent variables of interest are academic years since suffrage interacted with one of our three measures of advantage: state-level pre-suffrage education levels (columns 1 and 4); city-level black share of the population (columns 2 and 5); and whether the city is located in the South (columns 3 and 6.) All regressions include controls for state-level characteristics, and city and academic year fixed effects. Estimates are weighted using city population in 1910, and standard errors are clustered on state. The sample consists of all cities with available expenditure, revenue and enrollment data, which we observe for at least 7 years, and which are not outliers. Source: 1909 to 1911 and 1913 to 1915 Report of the Commissioner of Education, and 1917 to 1927 Biennial Survey of Education for cities with populations of 10,000 and over. ${ }^{*} \mathrm{p}<0.10,{ }^{* *} \mathrm{p}<0.05$, $* * * \mathrm{p}<0.01$. 


\section{Table A.16: Relationship between County and White Education Expenditures - Georgia and South Carolina}

\begin{tabular}{lcc}
\hline \hline Expenditures, all schools & $0.945^{* * *}$ & \\
& $(0.022)$ & \\
& & \\
$-\mathrm{x}$ Post-1920 & $-0.055^{* * *}$ & \\
& $(0.015)$ & \\
& & $1.707^{* * *}$ \\
Exp. per pupil, all schools & $(0.173)$ \\
& & \\
$-\mathrm{x}$ Post-1920 & -0.172 \\
& & $(0.130)$
\end{tabular}

Ln Expenditures, all schools

- x Post-1920

- x Post-1920

\begin{tabular}{lcccc}
\hline Mean Y & 306675.58 & 35.56 & 11.69 & 3.32 \\
$\mathrm{~N}$ & 4154 & 4154 & 4154 & 4154 \\
\hline \hline
\end{tabular}

Notes: This table shows the within-county relationship between pre- and post1920 local expenditures across all schools (column 1), expenditures per pupil (column 2), ln expenditures (column 3), and ln expenditures per pupil (column 4) and the corresponding measure for whites (e.g., total expenditures for white schools in column 1). Regressions include county and year fixed effects. Estimates weighted by total school enrollment in the county. Standard errors clustered on county shown in parenthesis. The sample is limited to Georgia and South Carolina, since those are the only states with available data before and after $1920^{*} \mathrm{p}<0.10,{ }^{* *} \mathrm{p}<0.05,{ }^{* * *} \mathrm{p}<0.01$. Source: ICPSR data series: "County-level school enrollment and resources in ten segregated Southern states, 1910-1940" 


\section{Table A.17: Relationship between County and Black Education Expenditures - Georgia and South Carolina}

\begin{tabular}{lc}
\hline \hline Expenditures, all schools & 0.034 \\
& $(0.024)$ \\
& $0.069^{* * *}$ \\
x Post-1920 & $(0.013)$
\end{tabular}

Exp. per pupil, all schools

$-0.067$

- x Post-1920

$0.199^{* * *}$

(0.064)

Ln Expenditures, all schools

$0.433^{* * *}$

- x Post-1920

$0.195^{* * *}$

(0.042)

Ln Exp. per pupil, all schools

$0.348^{* * *}$

(0.063)

\begin{tabular}{lcccc}
$-\mathrm{x}$ Post-1920 & & & & $\begin{array}{c}0.165^{* *} \\
(0.069)\end{array}$ \\
\hline Mean Y & 37212.79 & 5.99 & 9.53 & 1.48 \\
N & 4154 & 4154 & 4154 & 4154 \\
\hline \hline
\end{tabular}

Notes: This table shows the within-county relationship between pre- and post1920 local expenditures across all schools (column 1), expenditures per pupil (column 2), ln expenditures (column 3), and ln expenditures per pupil (column 4) and the corresponding measure for blacks (e.g., total expenditures for black schools in column 1). Regressions include county and year fixed effects. Estimates weighted by total school enrollment in the county. Standard errors clustered on county shown in parenthesis. The sample is limited to Georgia and South Carolina, since those are the only states with available data before and after $1920^{*} \mathrm{p}<0.10,{ }^{* *} \mathrm{p}<0.05,{ }^{* * *} \mathrm{p}<0.01$. Source: ICPSR data series: "County-level school enrollment and resources in ten segregated Southern states, 1910-1940". 
Table A.18: Effect of Suffrage on Years of Education Mandatory vs Voluntary States

\begin{tabular}{lccc}
\hline \hline & All & Whites & Blacks \\
\hline \hline A: Interaction with Mandatory States & & & \\
\cline { 1 - 3 } Suff Share 0-15 & 0.052 & 0.040 & $0.643^{*}$ \\
& $(0.199)$ & $(0.195)$ & $(0.356)$ \\
Suff Share 0-15 x Mandatory States & $0.321^{* * *}$ & 0.202 & $0.528^{* *}$ \\
& $(0.105)$ & $(0.122)$ & $(0.221)$ \\
\hline Mean Education & 9.647 & 9.967 & 6.810 \\
Observations & 1555475 & 1393855 & 157028 \\
\hline B: Keep Voluntary States Only & & & \\
Suff Share 0-15 & -0.069 & -0.054 & $0.723^{* *}$ \\
& $(0.206)$ & $(0.202)$ & $(0.330)$ \\
\hline Mean Education & 10.027 & 10.110 & 8.103 \\
Observations & 1220439 & 1169065 & 47218 \\
\hline \hline
\end{tabular}

Notes: This table contains results obtained when the dependent variable is years of education and the main independent variable is suffrage exposure, which is defined as the share of time between birth and age 15 that an individual was exposed to a suffrage law in his state of birth. In Panel A, suffrage exposure is interacted with indicators for "mandatory" and voluntary states, where "mandatory states" are the state that did not pass suffrage prior to the Nineteenth Amendment nor voluntarily ratified it. In Panel $\mathrm{B}$, the sample is restricted to states that passed suffrage voluntarily as defined above. All regressions include controls for demographics and state-level characteristics, birth state and birth year fixed effects, birth state linear time trends, as well as region-by-birth year and census year-by-birth year fixed effects. Estimates are weighted using Census sample weights, and standard errors are clustered on the state of birth. The sample consists of individuals born between 1880 and 1930, and that are at least 20 years old at the time of observation. We exclude states that passed suffrage prior to 1900. Source: 1940-1960 decennial censuses. ${ }^{*} \mathrm{p}<0.10,{ }^{*} \mathrm{p}<0.05,{ }^{* * *} \mathrm{p}<0.01$.

Table A.19: Effect of Suffrage on Years of Education By Whether Individual Migrated From State of Birth

\begin{tabular}{lccccccc}
\hline \hline & \multicolumn{3}{c}{ Whites } & & \multicolumn{3}{c}{ Blacks } \\
\cline { 2 - 3 } \cline { 7 - 8 } & All & Non Movers & Movers & All & Non Movers & Movers \\
\hline Suff Share 0-15 & 0.062 & 0.006 & 0.215 & & $0.884^{* * *}$ & $1.342^{* * *}$ & 0.485 \\
& $(0.197)$ & $(0.199)$ & $(0.170)$ & & $(0.295)$ & $(0.483)$ & $(0.501)$ \\
\hline Mean Education & 9.967 & 9.743 & 10.447 & & 6.810 & 6.320 & 7.505 \\
Observations & 1393855 & 949891 & 443964 & & 157028 & 92760 & 64268 \\
\hline \hline
\end{tabular}

Notes: This table contains results obtained when the dependent variable is years of education and the main independent variable is suffrage exposure, which is defined as the share of time between birth and age 15 that an individual was exposed to a suffrage law in his state of birth. All regressions include controls for demographics and state-level characteristics, birth state and birth year fixed effects, birth state linear time trends, as well as region-by-birth year and census year-by-birth year fixed effects. Estimates are weighted using Census sample weights, and standard errors are clustered on the state of birth. The sample consists of individuals born between 1880 and 1930, and that are at least 20 years old at the time of observation. We exclude states that passed suffrage prior to 1900. Source: 1940-1960 decennial censuses. ${ }^{*} \mathrm{p}<0.10,{ }^{* *} \mathrm{p}<0.05, * * * \mathrm{p}<0.01$. 
Table A.20: Effect of Suffrage on Years of Education Sensitivity to Census

\begin{tabular}{lccccc}
\hline \hline & 1940 & 1950 & 1960 & 1950,1940 Pop & 1960,1940 Pop \\
\hline \hline$\underline{\text { A: Blacks }}$ & & & & & \\
\hline Suff Share 0-15 & 0.234 & $1.530^{* *}$ & $0.957^{* *}$ & $2.892^{* *}$ & $1.191^{* *}$ \\
& $(0.296)$ & $(0.693)$ & $(0.389)$ & $(1.349)$ & $(0.505)$ \\
\hline Mean Education & 6.009 & 6.984 & 7.272 & 6.426 & 6.502 \\
Observations & 61004 & 22447 & 73577 & 15839 & 50924 \\
\hline B: Whites & & & & & \\
Suff Share 0-15 & 0.084 & 0.231 & -0.064 & 0.229 & -0.046 \\
& $(0.178)$ & $(0.231)$ & $(0.205)$ & $(0.207)$ & $(0.211)$ \\
\hline Mean Education & 9.567 & 10.056 & 10.173 & 9.704 & 9.735 \\
Observations & 509583 & 204510 & 679762 & 148663 & 483804 \\
\hline \hline
\end{tabular}

Notes: This table contains results obtained when the dependent variable is years of education and the main independent variable is suffrage exposure, which is defined as the share of time between birth and age 15 that an individual was exposed to a suffrage law in his state of birth. All regressions include controls for demographics and state-level characteristics, birth state and birth year fixed effects, birth state linear time trends, as well as region-by-birth year and census year-by-birth year fixed effects. Estimates are weighted using Census sample weights, and standard errors are clustered on the state of birth. The sample consists of individuals born between 1880 and 1930, and that are at least 20 years old at the time of observation. We exclude states that passed suffrage prior to 1900 . Source: $1940-1960$ decennial censuses. $* \mathrm{p}<0.10,{ }^{* *}$ $\mathrm{p}<0.05,{ }^{* * *} \mathrm{p}<0.01$.

\section{Table A.21: Effect of Suffrage on Years of Education - Keep Early States}

\begin{tabular}{|c|c|c|c|c|c|c|c|}
\hline & \multirow[b]{2}{*}{ All } & \multirow[b]{2}{*}{ Whites } & \multirow[b]{2}{*}{ Blacks } & \multicolumn{2}{|c|}{ Whites } & \multicolumn{2}{|c|}{ Blacks } \\
\hline & & & & Males & Females & Males & Females \\
\hline \multirow[t]{2}{*}{ Suff Share 0-15 } & 0.122 & 0.091 & $0.926^{* * *}$ & 0.088 & 0.091 & $1.372^{*}$ & $0.560^{* *}$ \\
\hline & $(0.189)$ & $(0.182)$ & $(0.295)$ & $(0.180)$ & $(0.200)$ & $(0.699)$ & $(0.265)$ \\
\hline Mean Education & 9.671 & 9.987 & 6.813 & 9.873 & 10.097 & 6.403 & 7.175 \\
\hline R-Squared & 0.195 & 0.125 & 0.215 & 0.135 & 0.116 & 0.208 & 0.213 \\
\hline Observations & 1581878 & 1419943 & 157155 & 701079 & 718864 & 74410 & 82745 \\
\hline
\end{tabular}

Notes: The sample includes all states, including those that passed suffrage prior to 1900 . Suff Share 0-15 is defined as the share of time between birth and age 15 that suffrage law passed in an individual's state of birth. All regressions include controls for demographics and state-level characteristics, birth state and birth year fixed effects, birth state linear time trends, as well as region-by-birth year and census year-by-birth year fixed effects. Estimates are weighted using Census sample weights, and standard errors are clustered on the state of birth. The sample consists of individuals born between 1880 and 1930, and that are at least 20 years old at the time of observation. Source: $1940-1960$ decennial censuses. ${ }^{*} \mathrm{p}<0.10,{ }^{* *}$ $\mathrm{p}<0.05, * * * \mathrm{p}<0.01$. 


\section{Table A.22: Effect of Suffrage on Years of Education - Individuals 25 or Older Only}

\begin{tabular}{|c|c|c|c|c|c|c|c|}
\hline & \multirow[b]{2}{*}{ All } & \multirow[b]{2}{*}{ Whites } & \multirow[b]{2}{*}{ Blacks } & \multicolumn{2}{|c|}{ Whites } & \multicolumn{2}{|c|}{ Blacks } \\
\hline & & & & Males & Females & Males & Females \\
\hline \multirow[t]{2}{*}{ Suff Share 0-15 } & 0.091 & 0.051 & $1.044^{* * *}$ & 0.014 & 0.085 & $1.564^{* *}$ & $0.586^{*}$ \\
\hline & $(0.207)$ & $(0.201)$ & $(0.266)$ & $(0.196)$ & $(0.225)$ & $(0.685)$ & $(0.325)$ \\
\hline Mean Education & 9.568 & 9.888 & 6.706 & 9.777 & 9.995 & 6.320 & 7.048 \\
\hline R-Squared & 0.192 & 0.122 & 0.213 & 0.133 & 0.112 & 0.207 & 0.210 \\
\hline Observations & 1424162 & 1276966 & 143098 & 629908 & 647058 & 67855 & 75243 \\
\hline
\end{tabular}

Notes: The sample excludes states that passed suffrage prior to 1900 , and is composed of individuals age $\geq 25$. Suff Share $0-15$ is defined as the share of time between birth and age 15 that suffrage law passed in an individual's state of birth. All regressions include controls for demographics and state-level characteristics, birth state and birth year fixed effects, birth state linear time trends, as well as region-by-birth year and census year-by-birth year fixed effects. Estimates are weighted using Census sample weights, and standard errors are clustered on the state of birth. Source: 1940-1960 decennial censuses. ${ }^{*} \mathrm{p}<0.10,{ }^{* *} \mathrm{p}<0.05,{ }^{* * *} \mathrm{p}<0.01$.

Table A.23: Effect of Suffrage on Years of Education Sensitivity to Measure of Exposure

\begin{tabular}{lccc}
\hline \hline & All & Whites & Blacks \\
\hline Suffrage by 15 & 0.009 & -0.001 & $0.292^{* * *}$ \\
& $(0.021)$ & $(0.022)$ & $(0.060)$ \\
\hline Mean Education & 9.647 & 9.967 & 6.810 \\
Observations & 1555475 & 1393855 & 157028 \\
\hline \hline
\end{tabular}

Notes: This table contains results obtained when the dependent variable is years of education and the main independent variable is suffrage exposure, which is equal to one if an individual is exposed to suffrage in his state of birth at age 15 or younger. All regressions include controls for demographics and state-level characteristics, birth state and birth year fixed effects, birth state linear time trends, as well as region-by-birth year and census year-by-birth year fixed effects. Estimates are weighted using Census sample weights, and standard errors are clustered on the state of birth The sample consists of individuals born between 1880 and 1930, and that are at least 20 years old at the time of observation. We exclude states that passed suffrage prior to 1900 Source: 1940-1960 decennial censuses. ${ }^{*} \mathrm{p}<0.10,{ }^{* *} \mathrm{p}<0.05$, $* * * \mathrm{p}<0.01$. 


\section{Table A.24: Effect of Suffrage on Years of Education - Sensitivity to State Controls}

\begin{tabular}{lccc}
\hline \hline & All & Whites & Blacks \\
\hline \hline A: Baseline: State Controls At Birth & & & \\
Suff Share 0-15 & 0.091 & 0.062 & $0.884^{* * *}$ \\
\hline B: Substitute Cumulative State Controls 0-15 & $(0.203)$ & $(0.197)$ & $(0.295)$ \\
\hline Suff Share 0-15 & 0.150 & 0.128 & $0.875^{* * *}$ \\
& $(0.181)$ & $(0.172)$ & $(0.300)$ \\
\hline C: Substitute Pre-State Controls ${ }^{*}$ Birthyear & & & \\
Suff Share 0-15 & 0.046 & 0.004 & $1.034^{* * *}$ \\
& $(0.253)$ & $(0.239)$ & $(0.246)$ \\
\hline D: Drop Controls for Compulsory Schooling & & & \\
\hline Suff Share 0-15 & 0.089 & 0.059 & $0.862^{* * *}$ \\
& $(0.197)$ & $(0.196)$ & $(0.302)$ \\
\hline E: Dynamic Controls for Compulsory Schooling & & & \\
\hline Suff Share 0-15 & 0.073 & 0.036 & $0.805^{* * *}$ \\
& $(0.200)$ & $(0.189)$ & $(0.289)$ \\
\hline F: Add Controls for Progressive Laws & & & \\
\hline Suff Share 0-15 & 0.064 & 0.033 & $0.994^{* * *}$ \\
& $(0.206)$ & $(0.201)$ & $(0.265)$ \\
\hline G: Add Trend in Pre-Education & & & \\
\hline Suff Share 0-15 & 0.097 & 0.062 & $0.884^{* * *}$ \\
& $(0.202)$ & $(0.197)$ & $(0.295)$ \\
\hline Suff Share 0-15 & -0.066 & -0.066 & $1.476^{* * *}$ \\
\hline \hline
\end{tabular}

Notes: This table contains results obtained when the dependent variable is years of education and the main independent variable is suffrage exposure, which is defined as the share of time between birth and age 15 that an individual was exposed to a suffrage law in his state of birth. Each panel and column presents estimates from separate regressions. Each panel title refers to a separate robustness exercise, see text for details. Panel E reports results where we include a control for the relevant compulsory schooling law at each age, from age 1 to 18 . All regressions include controls for demographics, birth state and birth year fixed effects, birth state linear time trends, as well as region-by-birth year and census year-by-birth year fixed effects. Estimates are weighted using Census sample weights, and standard errors are clustered on the state of birth. The sample consists of individuals born between 1880 and 1930, and that are at least 20 years old at the time of observation. We exclude states that passed suffrage prior to 1900. Source: 1940-1960 decennial censuses. ${ }^{*} \mathrm{p}<0.10,{ }^{* *} \mathrm{p}<0.05,{ }^{* * *} \mathrm{p}<0.01$. 


\section{Figure A.1: Effect of Suffrage on Presidential Turnout}

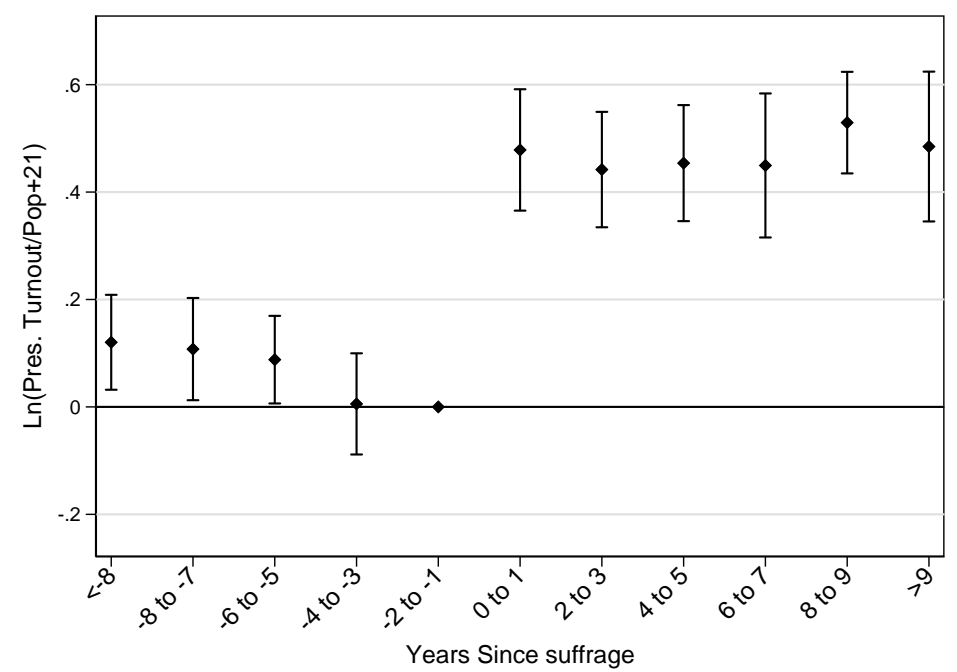

Notes: This figure plots the estimated coefficients obtained from an event study specification that analyzes the effect of suffrage on state-level presidential turnout, defined as the natural logarithm of total number of votes at the presidential elections divided by the voting eligible age, $21+$. We control for state and year fixed effects, weight the estimates using population weights, and cluster the standard errors at the state level. The two years prior to the passage of suffrage are the omitted category, so estimates are relative to that point. The sample excludes states that passed suffrage prior to 1900 . Sources: Turnout: "Electoral Data for Counties in the United States: Presidential and Congressional Races, 1840-1972" (ICPSR 8611); Population: 1900-1930 censuses. 


\section{Figure A.2: Voting on Progressive Bills After Suffrage - Total and Within-Politicians}

(i) Total

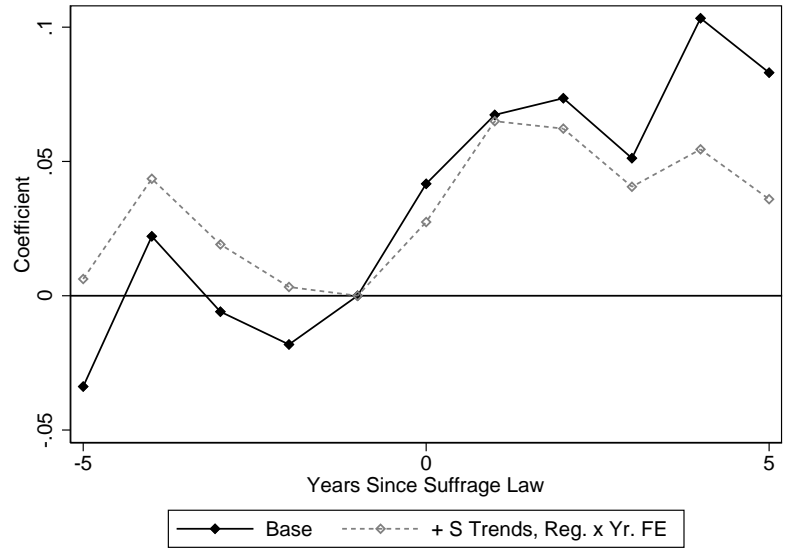

(ii) Within

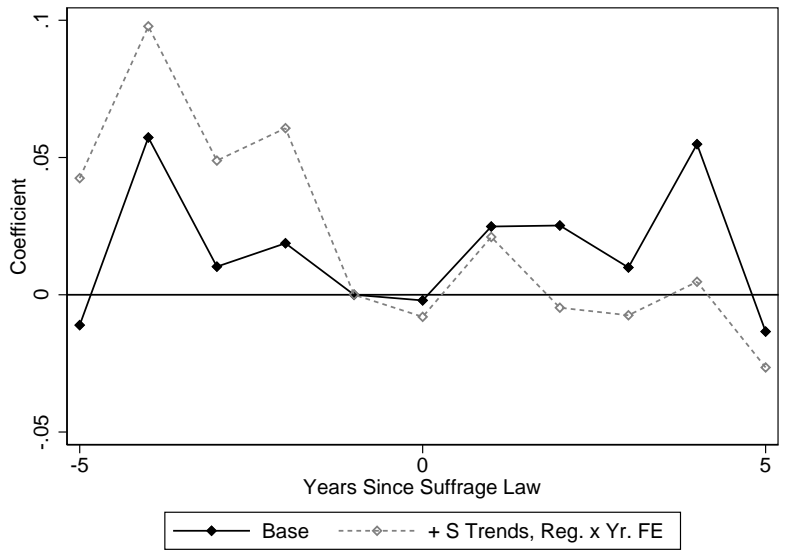

(i) Total

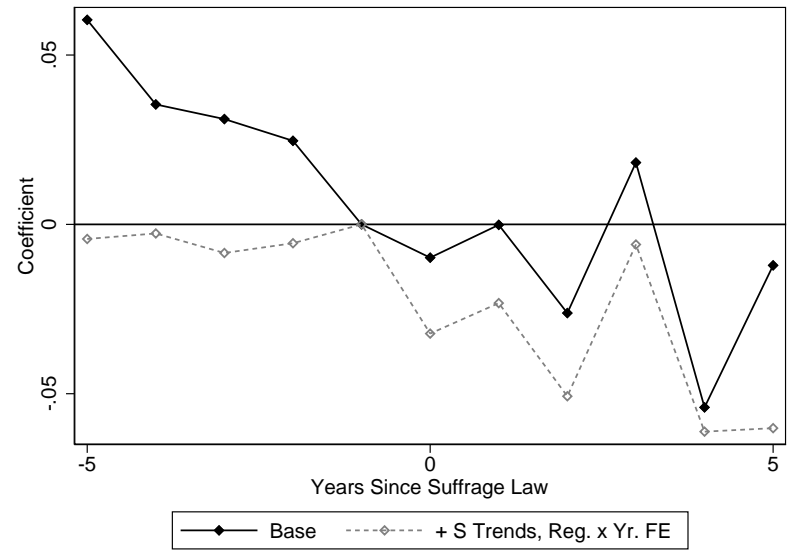

(ii) Within

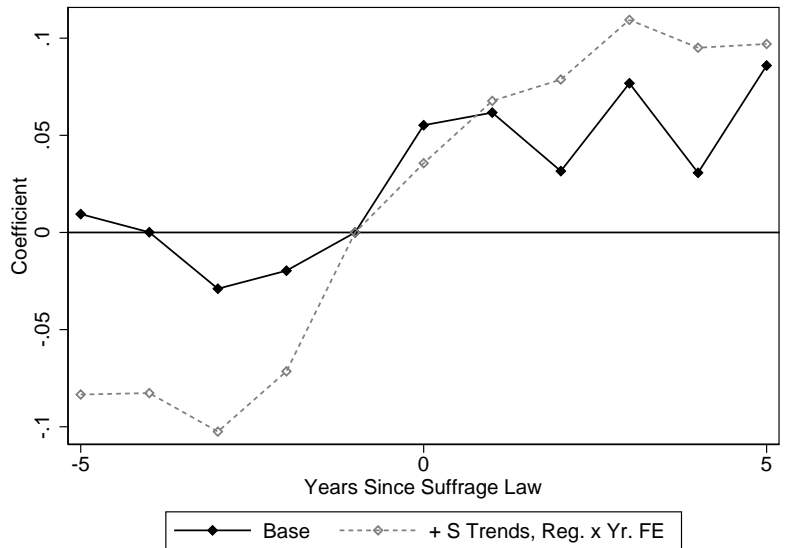

(c) Share No on Progressive Bills

(i) Total

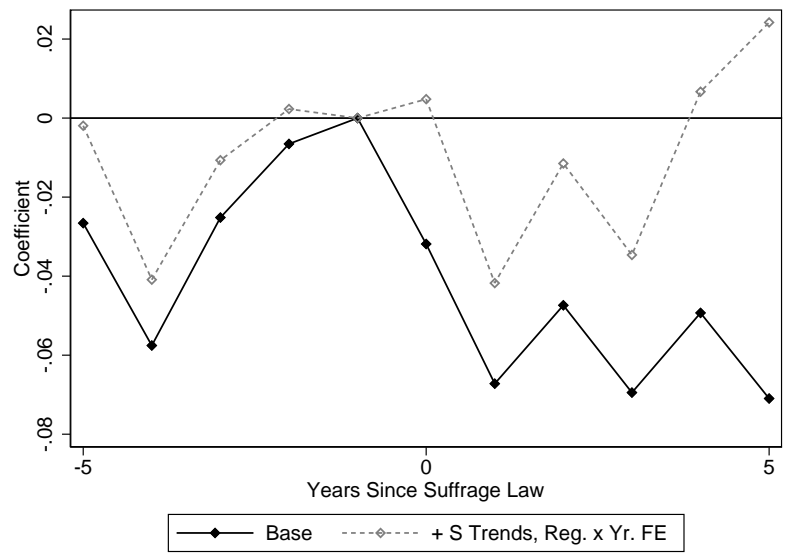

(ii) Within

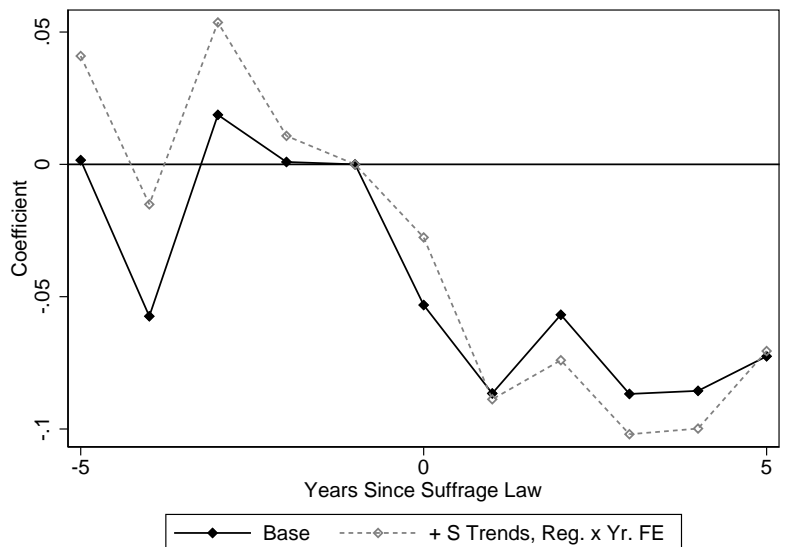

These figures are obtained from event study specifications that analyze the effect of suffrage on (i) the share of progressive bills that a senator voted for; (ii) the share of progressive bills that a senator abstained from; and (iii) the share of progressive bills that the senator voted against. The "Within" panels includes individual fixed effects, while the "Total" panels do not. "Base" specification in black diamonds includes year fixed effects and state fixed effects. Wee add state trends and region-by-year fixed effects as a robustness check, shown with the grey open diamonds. Event study coefficients are relative to $t=-1$. We group together the years $t \geq 5$ and $t \leq-5$, shown at the end-points. Standard errors are clustered at the state level. Sources: Coding of progressive and anti-progressive bills from Miller (2008), 1900-1930 Senate voting data from Votev63: Congressional Roll Call Votes Database (Lewis et al., 2019). 
Figure A.3: Average Educational Attainment Across Cohorts and Regions

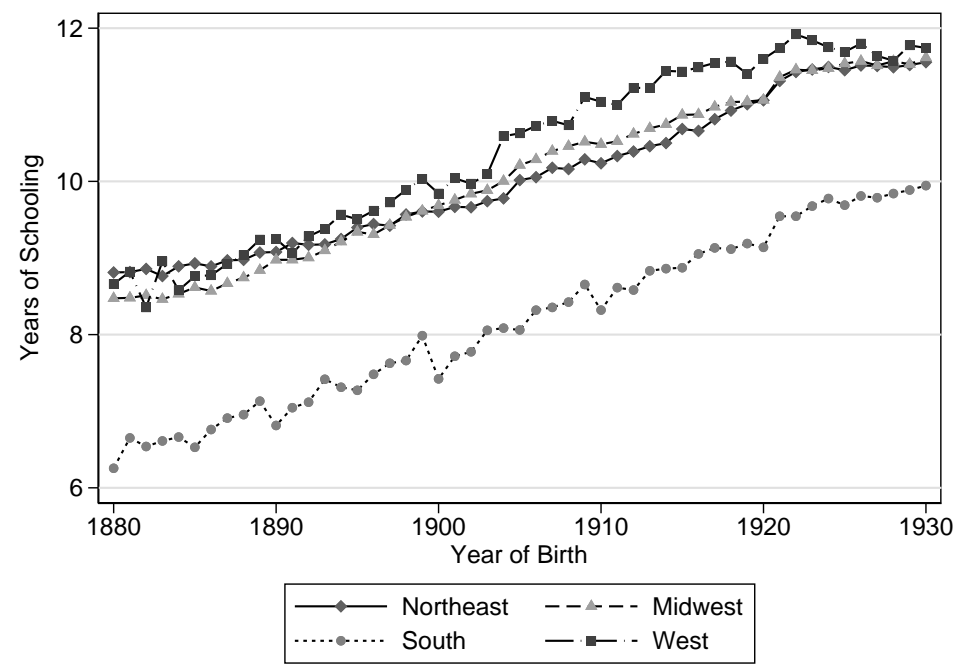

Notes: This figure plots the (weighted) average number of years of completed schooling for U.S. born residents by birth cohort and region. The sample consists of individuals born between 1880 and 1930, and that are at least 20 years old at the time of observation. We exclude states that passed suffrage prior to 1900. Source: 1940-1960 decennial censuses. 
Figure A.4: Relationship between Subgroup Effect of Suffrage on Years of Education and Pre-Suffrage Average Disadvantage
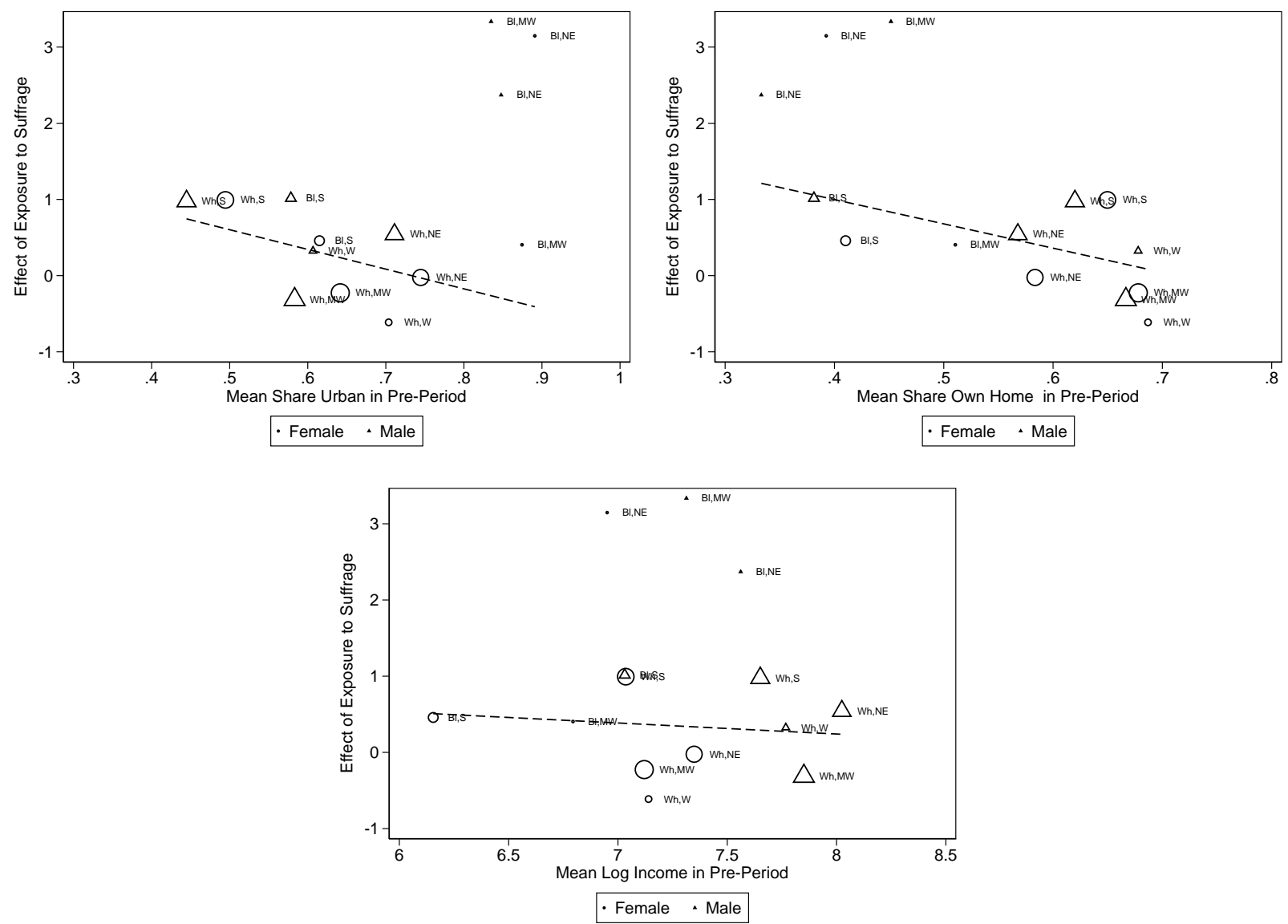

Notes: To create these figures, we first estimate specifications that analyze the effect of suffrage exposure on educational attainment separately for demographic groups defined according to region of birth, race and gender. We then plot the estimated coefficients along with the three different average pre-suffrage measure of disadvantage for each demographic group, with the circle/triangle size representing the number of observations in each group. Regions are abbreviated as follows: "S" for South, "W" for West, "MW" for Midwest, and "NE" for Northeast, and race is abbreviated as: "Bl" for black and "Wh" for white. We do not show blacks in the West due to their small sample size, but an equivalent figure that includes all groups is available on request. All regressions include controls for demographics and state-level characteristics, birth state and birth year fixed effects, birth state linear time trends, as well as region-by-birth year and census year-by-birth year fixed effects. Estimates are weighted using Census sample weights, and standard errors are clustered on the state of birth. The sample consists of individuals born between 1880 and 1930, and that are at least 20 years old at the time of observation. We exclude states that passed suffrage prior to 1900. Source: 1940-1960 decennial censuses. 
Figure A.5: Effect of Suffrage at Each Age of Exposure on Years of Education By South/Non-South

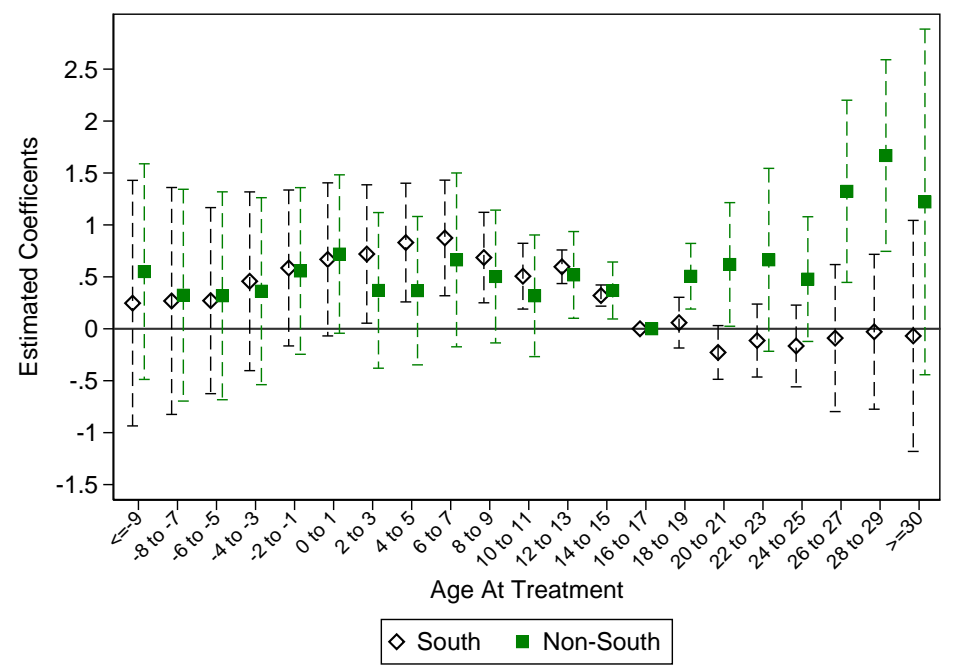

(a) Blacks

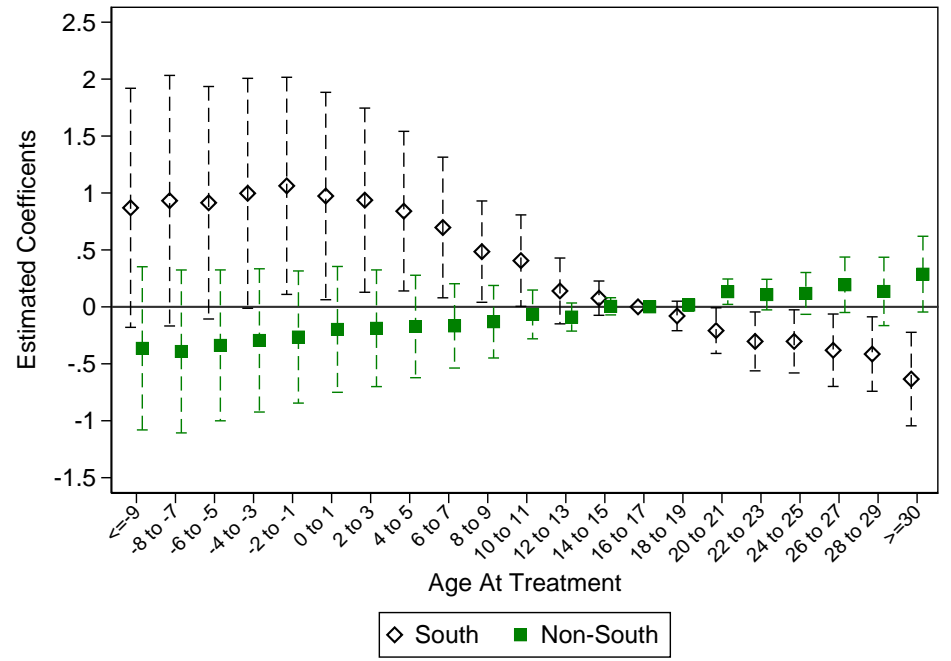

(b) Whites

Notes: This figure plots the estimated coefficients (and 95\% confidence intervals) obtained from event study specifications that analyze the effect of suffrage at each age of first exposure on educational attainment and includes an interaction between the age at treatment dummies and whether the state of birth is in the South or Non-South, estimated separately for whites and blacks. All specifications include controls for demographics and state-level characteristics, birth state and birth year fixed effects, birth state linear time trends, as well as region-by-birth year and census year-by-birth year fixed effects. Age at treatment 16 to 17 is the omitted category so estimates are relative to that point. Estimates are weighted using Census sample weights, and standard errors are clustered on the state of birth. The sample consists of individuals born between 1880 and 1930, and that are at least 20 years old at the time of observation. We exclude states that passed suffrage prior to 1900. Source: 1940-1960 decennial censuses. 
Figure A.6: Effect of Suffrage at Each Age of Exposure on Literacy By Race

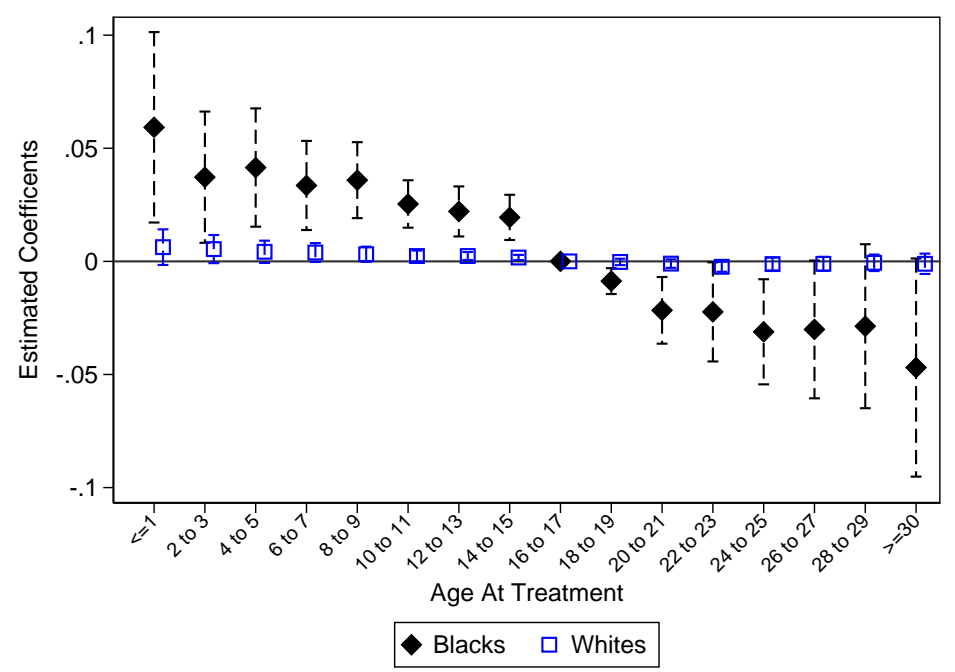

Notes: This figure plots the estimated coefficients (and 95\% confidence intervals) obtained from event study specifications that analyze the effect of suffrage at each age of first exposure on literacy attainment, separately for whites and blacks. All specifications include controls for demographics and state-level characteristics, birth state and birth year fixed effects, birth state linear time trends, as well as region-by-birth year and census year-by-birth year fixed effects. Age at treatment 16 to 17 is the omitted category so estimates are relative to that point. Estimates are weighted using Census sample weights, and standard errors are clustered on the state of birth. The sample consists of individuals born between 1880 and 1915, and that are at least 15 years old at the time of observation. We exclude states that passed suffrage prior to 1900. Source: 1920-1930 decennial censuses. 


\section{Figure A.7: Effect of Suffrage at Each Age of First Exposure on Log Earnings - By South/Non-South}

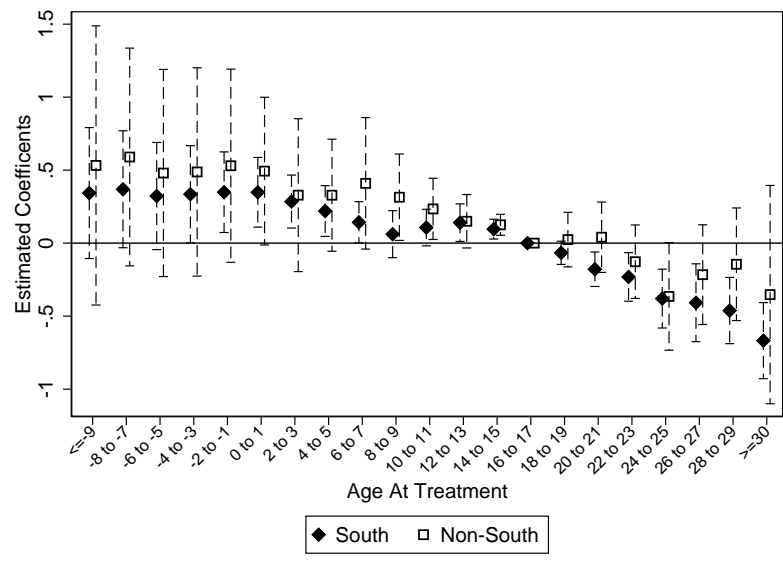

(a) Blacks

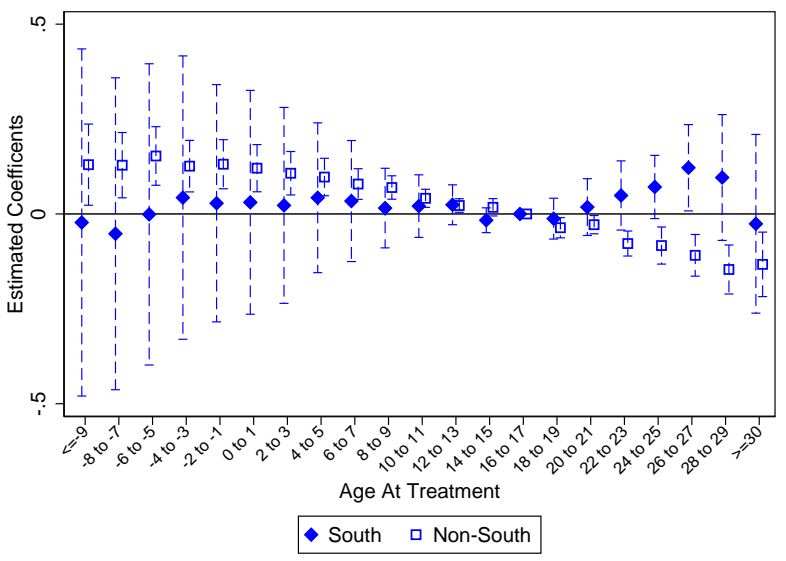

(b) Whites

Notes: This figure plots the estimated coefficients (and 95\% confidence intervals) obtained from event study specifications that analyze the effect of suffrage at each age of first exposure on log income, and includes an interaction between the age at treatment dummies and whether the state of birth is in the South or Non-South, estimated separately for whites and blacks. All specifications include controls for demographics and state-level characteristics, birth state and birth year fixed effects, birth state linear time trends, as well as region-by-birth year and census year-by-birth year fixed effects. Age at treatment 16 to 17 is the omitted category so estimates are relative to that point. Estimates are weighted using Census sample weights, and standard errors are clustered on the state of birth. The sample consists of individuals born between 1880 and 1930 , and that are at between 30 and 65 years old at the time of observation. We exclude states that passed suffrage prior to 1900. Source: 1940-1960 decennial censuses. 


\section{Figure A.8: Distributional Effects of Exposure to Suffrage (Ages 0-15) on Earnings - By South/Non-South}

(a) Whites

(i) South

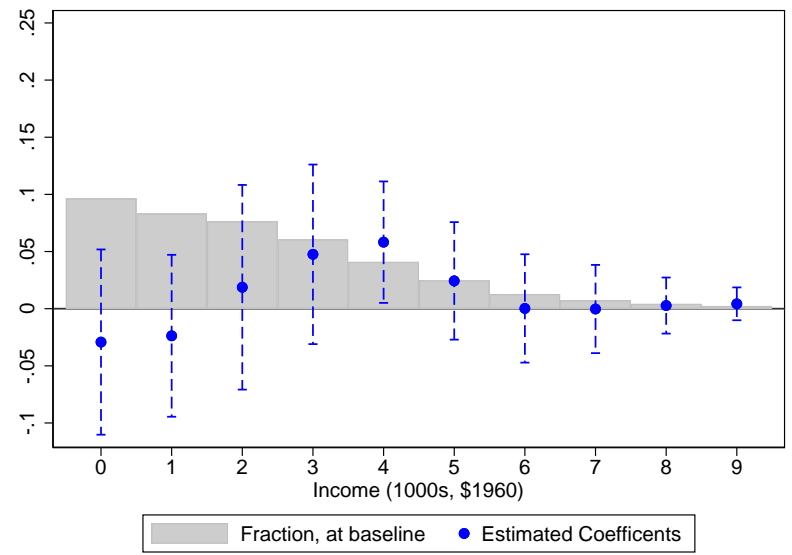

(ii) Non-South

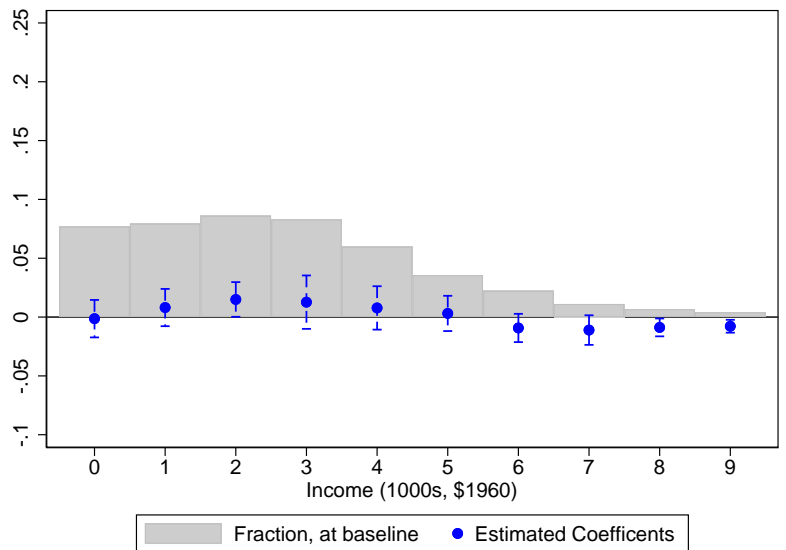

(b) Blacks

(i) South

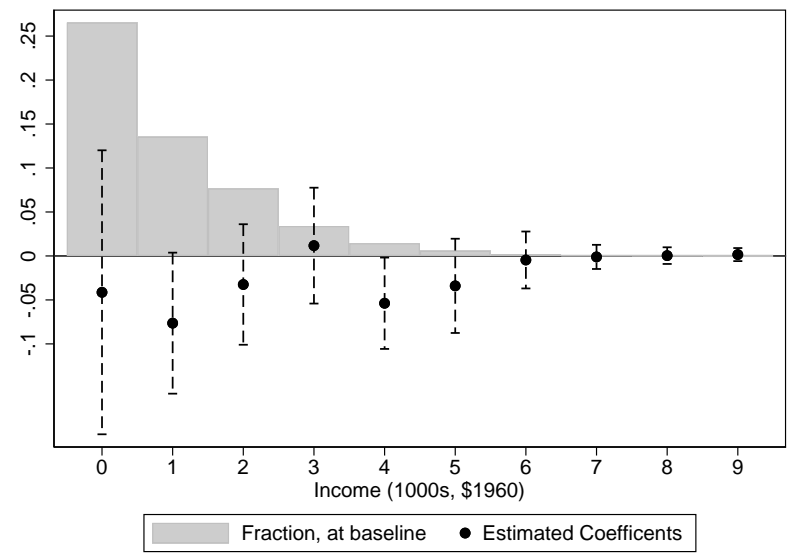

(ii) Non-South

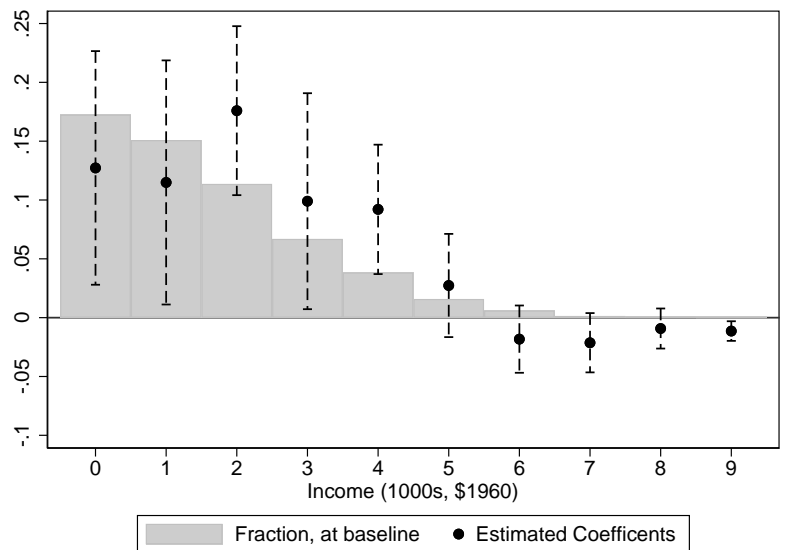

Notes: These figures plot the estimated coefficients (and 95\% confidence intervals) from a series of regressions of indicators for whether an individual had earnings ( $\$ 1960$ at least as great as $x$, where $x$ is represented on the $\mathrm{x}$-axis, on suffrage exposure between ages $0-15$. Regressions are estimated separately for white and blacks and by south/non-south, and they include controls for demographics and state-level characteristics, birth state and birth year fixed effects, birth state linear time trends, as well as region-by-birth year and census year-by-birth year fixed effects. Estimates are weighted using Census sample weights, and standard errors are clustered on the state of birth. For reference, we also include a histogram of the earnings of individuals who were exposed to suffrage after age 15, who serve as the comparison group in these regressions. The sample consists of individuals born between 1880 and 1930, and that are between the ages of 30-60 at the time of observation. We exclude states that passed suffrage prior to 1900. Source: 1940-1960 decennial censuses. 


\section{Figure A.9: Effect of Placebo Suffrage Laws on Years of Education - By Race}

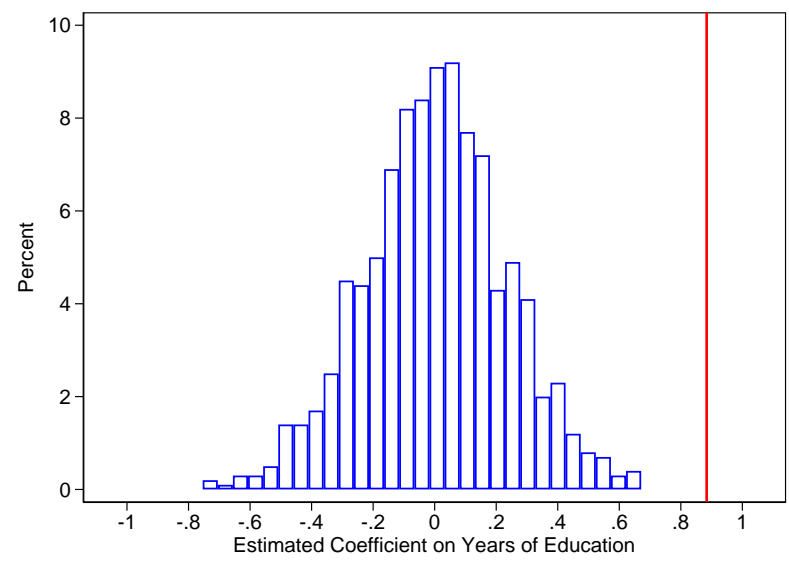

(a) Blacks

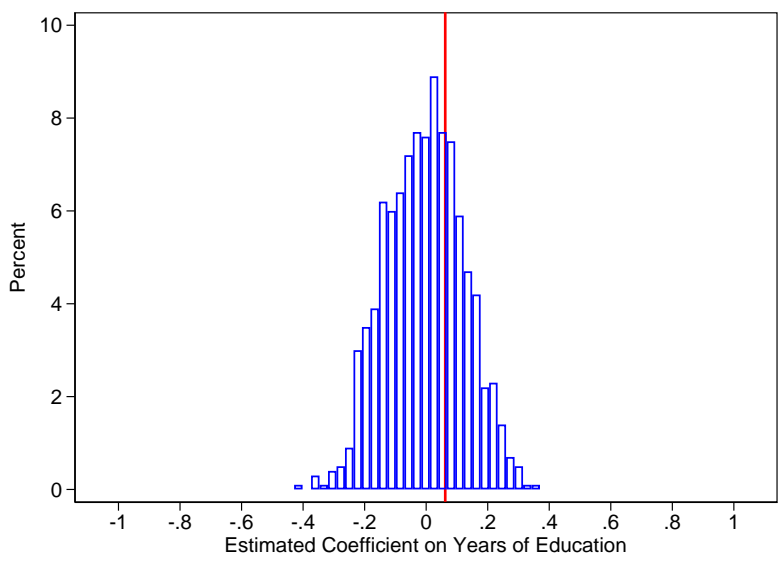

(b) Whites

Notes: These figures plot the distribution of the estimated difference-in-differences coefficients on suffrage exposure obtained from 1000 repetitions where we randomly assign a year of suffrage between 1910 and 1920 to each state. The red line indicates the estimated effect when we use the real suffrage laws. The empirical p-value for blacks is $<0.01$ and for whites is 0.31 . All specifications include controls for demographics and state-level characteristics, birth state and birth year fixed effects, birth state linear time trends, as well as region-by-birth year and census year-by-birth year fixed effects. Estimates are weighted using Census sample weights. The sample consists of individuals born between 1880 and 1930, and that are at least 20 years old at the time of observation. We exclude states that passed suffrage prior to 1900. Source: 1940-1960 decennial censuses. 
Figure A.10: Effect of Suffrage at Each Age of First Exposure on Years of Education Sensitivity To Different Age of First Exposure Windows, Blacks

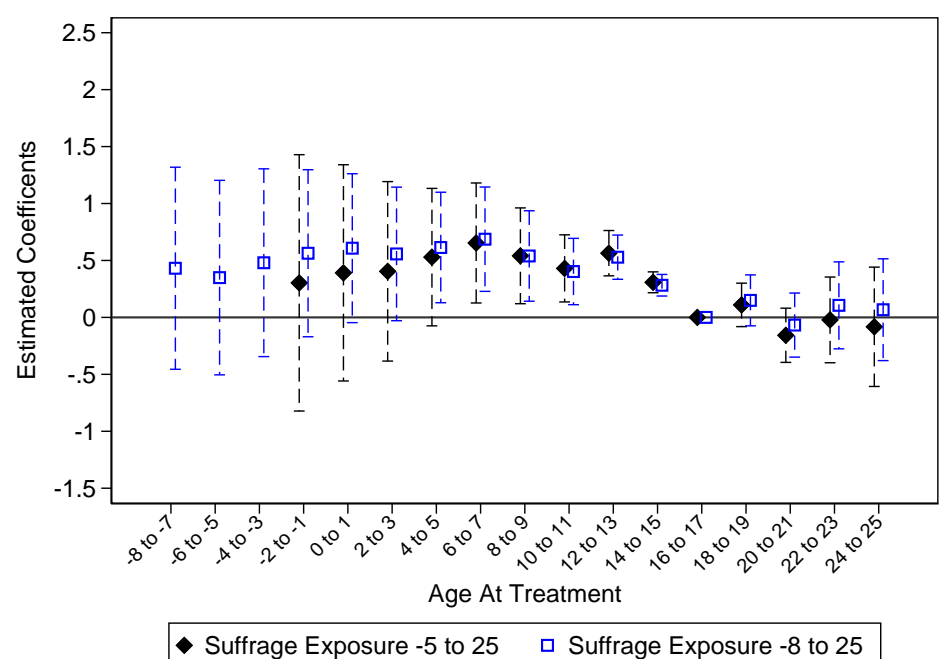

Notes: This figure plots the estimated coefficients (and 95\% confidence intervals) obtained from event study specifications that analyze the effect of suffrage at each age of first exposure on educational attainment, estimated for blacks only separately for cohorts exposed to suffrage between -5 and 25 and between -8 and 25. All specifications include controls for demographics and state-level characteristics, birth state and birth year fixed effects, birth state linear time trends, as well as region-by-birth year and census year-by-birth year fixed effects. Age at treatment 16 to 17 is the omitted category so estimates are relative to that point. Estimates are weighted using Census sample weights, and standard errors are clustered on the state of birth. The sample consists of individuals born between 1880 and 1930, and that are at least 20 years old at the time of observation. We exclude states that passed suffrage prior to 1900. Source: 1940-1960 decennial censuses. 


\section{B Appendix B: Data Appendix}

Voter Turnout We obtain the number of votes cast in each presidential election for our analysis of voter turnout in Section 1.1 from the ICPSR data series \#8611: "Electoral Data for Counties in the United States: Presidential and Congressional Races, 1840-1972" (Clubb, Flanigan and Zingale, 2006). ${ }^{45}$ We estimate the population over age 21 using decennial census data (Ruggles et al., 2020), with linear interpolation for the intercensal years.

State Controls We source these measures from the data set used in Lleras-Muney (2002) (and made available on Adriana Lleras-Muney's website) ${ }^{46}$ and ICPSR data series \#2896 "Historical, Demographic, Economic, and Social Data: The United States, 1790-2002" (Haines and Inter-university Consortium for Political and Social Research, 2010). The ICPSR series harmonizes information from Census of Manufacturing and Census of Agriculture .47 The data from Lleras-Muney (2002) span the years 1915-1939 and have been utilized in many previous studies of this time period, including Goldin and Katz (2010). We use ICPSR \#2896 to create an equivalent set of controls spanning from 1880-1914. We linearly interpolate between decennial census observations to create annual measures. ${ }^{48}$ Finally, we use the 1870-1930 decennial censuses to generate estimates of literacy at birth for each state and cohort (Ruggles et al., 2020).

Compulsory Schooling We use data on compulsory schooling requirements from 1910 to 1913 used in Goldin and Katz (2003), and from 1914 to 1944 used in Acemoglu and Angrist (2000). ${ }^{49}$ We then determine the relevant schooling and labor laws for each cohort following the assignment rules in Stephens and Yang (2014). In particular, the measure of compulsory attendance, $C A$ is defined for each cohort $c$ born in state $s$ as follows:

$C A_{c s}=\min \left\{\right.$ DropoutAge $_{c s}-$ EnrollmentAge $_{c s}$, Years of SchoolNeeded to Dropout cs , where each of the components of $C A$ are determined by the prevailing laws in state $s$ in the year that $c$ turns 14. Child labor, $C L_{c s}$ is defined as: $C L_{c s}=\max \left\{\right.$ WorkPermitAge $_{c s}-$ EnrollmentAge $e_{c s}$, Educationfor WorkPermit $\left.{ }_{c s}\right\}$. Since we only have these laws beginning in

\footnotetext{
${ }^{45}$ See http://www.icpsr. umich.edu/icpsrweb/ICPSR/studies/8611.

${ }^{46}$ These data are compiled from a number of sources. We accessed these data from Lleras-Muney's former website in April 2014, which has now been migrated to https://adriana-llerasmuney.squarespace.com/ data.

${ }^{47}$ See: http://www.icpsr.umich.edu/icpsrweb/ICPSR/studies/2896.

${ }^{48}$ Following Lleras-Muney (2002), we adjust all monetary values for inflation using the Consumer Price Index, 1982-1984 as the base period.

${ }^{49}$ For the data used in Acemoglu and Angrist (2000), we use the Stata dataset "schooling_laws_aa" in the data archive of Stephens and Yang (2014). For the data used in Goldin and Katz (2003), we use the data posted on Claudia Goldin's website. See: https://scholar.harvard.edu/goldin/pages/data.
} 
1910, we assume that cohorts that turned 14 before 1910 (born between 1880-1896) were exposed to the 1910 laws.

Rosenwald Initiative We aggregate the county-level Rosenwald student exposure measure from the data archive of Aaronson and Mazumder (2011) to the state-level to generate an individual measure of Rosenwald exposure during childhood.

Progressive Laws and New Deal Spending We hand-coded the years of progressive laws that appear in Appendix Table A.5 based on tables in Skocpol (1992), Kantor and Fishback (1996), and Depew, Edwards and Owens (2013). We obtain information on New Deal Spending used in Table A.6 from the data used in Fishback, Haines and Kantor (2007), and made available on Price Fishback's website: http://www.u.arizona.edu/ fishback/ Published_Research_Datasets.html.

Mortality Statistics The Mortality Statistics were originally published by the U.S. Bureau of the Census, but we obtained pdf files of historical statistics from 1900-1932 from the Centers for Disease Control and Prevention. Original pdfs can be downloaded from http://www.cdc.gov/nchs/products/vsus/vsus_1890_1938.htm. We used optical character recognition (OCR) to convert the pdfs to Excel files and a research assistant manually checked the values.

City-level Education Data During our period of interest, city-level education statistics were published either in the Report of the Commissioner of Education (RCE) (annually, academic years 1909/10 until 1915/16) or in the Biennial Survey of Education (BSE) (biennially, from 1917/18 on). We downloaded pdfs for all of the years we digitized, 1906 to 1911 and 1913 to 1928, from HathiTrust Digital Library (https://www.hathitrust.org/), except 1923/24, which we scanned ourselves for better image quality. We selected three tables to digitize in each year: the school census, which has enrollment and attendance; the "receipts of school systems", which contains sources of revenue; and the expenses and outlays table, which has total current expenditures. We digitized this information for all cities with populations over 10,000 using an external digitization service.

To obtain our final city panel data, we first harmonized the naming conventions across years by manually looking for cases where the name changed very slightly across years (e.g., "Windham (P. O. Willimantic)" became "Windham (P. O., Willimantic)"). Second, we manually identified cities that merged or split, and generated consistent names for these cities. Third, since the reporting categories for local revenue (city and county) varied across 
years, we aggregated these to create a comparable measure over time. We define revenue from local sources as total revenue minus revenue from the state.

Congressional Voting We draw on Congressional roll call data from Voteview (Lewis et al., 2019) and the coding of progressive bills used in Miller (2008) (and made available on Grant Miller's website) for our analysis of voting in the Senate in Section 1.1. ${ }^{50}$ The data include all votes by legislators in the Senate and the House of Representatives from 1900 to 1930, and indicators for whether the bill voted on was "progressive" or "anti-progressive." Following Miller (2008), we consider voting "no" on an anti-progressive bill or "yes" on a progressive bill to be a "progressive" vote. To be as inclusive as possible, we include votes on bills marked questionably progressive or questionably anti-progressive in this category.

County-level Education Expenditures To estimate "pass-through" of growth in county spending to black and white schools, we use a panel of county-level education expenditures for Georgia and South Carolina from 1910 to 1940 obtained from ICPSR (Carruthers and Wanamaker, 2019). These data were previously used in Carruthers and Wanamaker (2014). ${ }^{51}$ Expenditure data are available for South Carolina for every academic year, and for Georgia for every academic year between 1910-1922 and for every other academic year between 1922-1940. The data include information on expenditures for white schools, black schools, and total expenditures ${ }^{52}$ We compute expenditures per pupil by dividing expenditures by enrollment.

\footnotetext{
${ }^{50}$ For the coding of the progressive laws, see: https://ngmiller.people.stanford.edu/research, which we accessed on August 1, 2019.

${ }^{51}$ The data also include race-specific school spending for Louisiana and Arkansas, but for a shorter period (from 1922-1940 for Louisiana, and every other year from 1928-1940 for Arkansas.)

${ }^{52}$ Total expenditures are frequently larger than the sum of expenditures for white and black schools, which could represent administrative costs.
} 